\title{
DESENVOLVIMENTO DO VALE DO TIETÊ-PARANÁ: UM ENFOQUE DE ESTOQUES DE CAPITAIS
}

\author{
ELAINE MENDONÇA BERNARDES
}

\footnotetext{
Tese apresentada à Escola Superior de Agricultura “Luiz de Queiroz”, Universidade de São Paulo, para obtenção do título de Doutor em Ciências, Área de Concentração: Economia Aplicada.
}

\author{
P I R A C I C A B A \\ Estado de São Paulo - Brasil \\ Julho - 2002
}




\title{
DESENVOLVIMENTO DO VALE DO TIETÊ-PARANÁ: UM ENFOQUE DE ESTOQUES DE CAPITAIS
}

\author{
ELAINE MENDONÇA BERNARDES \\ Engenheiro Agrônomo
}

Orientador: Prof. Dr. FERNANDO CURI PERES

\begin{abstract}
Tese apresentada à Escola Superior de Agricultura “Luiz de Queiroz”, Universidade de São Paulo, para obtenção do título de Doutor em Ciências, Área de Concentração: Economia Aplicada.
\end{abstract}

\author{
P I R A C I C A B A \\ Estado de São Paulo - Brasil \\ Julho -2002
}




\section{Dados Internacionais de Catalogação na Publicação (CIP) DIVISÃO DE BIBLIOTECA E DOCUMENTAÇÃO - ESALQ/USP}

Bemardes, Ela ine Mendonça

Desenvolvimento do Vale do Tietê-Paraná: um enfoque de estoques de capita is/ Ela ine Mendonça Bemardes. - - Piracicaba, 2002.

$139 \mathrm{p}$.

Tese (doutorado) - Escola Superior de Agricultura Luiz de Queiroz, 2002. Bibliografia.

1. Capital humano 2. Capital social 3. Desenvolvimento econômico 4. Paraná 5. Projetos 6. Tietê, Rio 7. Valesı. Título

CDD 338.9

"Permitida a cópia total ou parcial deste documento, desde que citada a fonte - $O$ autor" 
a meu avô Lauro Bernardes, por tantas lições que ainda tento aprender. Com saudades, dedico 


\section{AGRADECIMENTOS}

Ao Prof. Fernando Curi Peres agradeço pela orientação segura, a confiança depositada e a convivência sempre cordial que mantivemos. Agradeço principalmente pela generosidade com que compartilha seus conhecimentos.

Ao Prof. G. Edward Schuh agradeço as sugestões a este estudo e a oportunidade única que me proporcionou de conviver, por alguns meses, com sua equipe de trabalho no H.H. Humprhey Institute da Universidade de Minnesota, EUA e com sua família.

Aos professores José Vicente Caixeta Filho, Alexandre Lahóz Mendonça de Barros, Marcia Azanha Ferraz Dias de Moraes, agradeço as sugestões e críticas tecidas ao projeto inicial de pesquisa. Ao professor Paulo Fernando de Cidade de Araújo, por sempre estimular seus alunos a se interessarem por desenvolvimento econômico.

À Paula Regina de Jesus Pinsetta Pavarina, sempre amiga, agradeço a enorme contribuição oferecida no decorrer de todo o período de realização deste trabalho.

A Patrícia Verônica Lima Sales, José Roberto F. Canziani, Daltro Cella, Aryeverton Fortes, que acompanharam diferentes fases desse trabalho, agradeço as sugestões, as críticas e a amizade.

Aos amigos Cleyse, Emerson, Casimiro e Alexandre Nunes, agradeço pela colaboração durante todo o período de estudos em Piracicaba. 
A meus pais, Darcy e Maria Zélia, e a meus irmãos e cunhados Edilene (e Márcio), Darcy Ricardo (e Fátima) e Luís Marcelo. A meu sobrinho Gabriel Mateus, sou grata pelos momentos de descontração e alegria.

À Helena Cardoso, que sempre prestativa, me ajudou com tabelas e gráficos e aos professores e funcionários DEAS/ESALQ que sempre com gentileza e cordialidade colaboraram para a realização deste trabalho.À Faculdade de Engenharia da Unesp, por permitir meu afastamento para cursar o doutorado.

À CAPES e ao CNPq, respectivamente pelas bolsas de doutorado e doutorado "sanduíche".

A tantos que, anonimamente, colaboraram para a obtenção dos dados utilizados no presente trabalho. 


\section{SUMÁRIO}

\begin{tabular}{|c|c|}
\hline \multicolumn{2}{|r|}{ 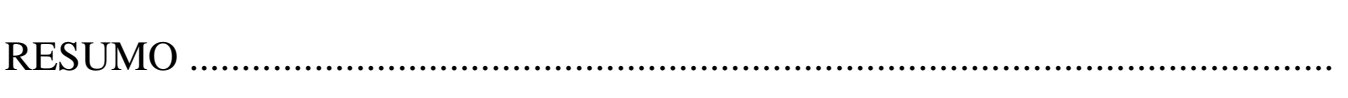 } \\
\hline \multicolumn{2}{|r|}{ SUMMARY } \\
\hline 1 & INTRODUÇÃO . \\
\hline 1.1 & Definição do problema e objetivo geral do estudo ....................................... \\
\hline 1.2 & 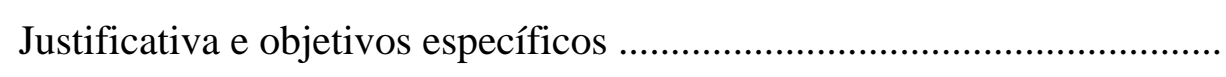 \\
\hline 2 & OS PROJETOS PARA O VALE DO TIETÊ-PARANÁ ... \\
\hline 2.1 & Estudos regionais de desenvolvimento para o Vale do Tietê-Paraná ....... \\
\hline 2.1 .1 & 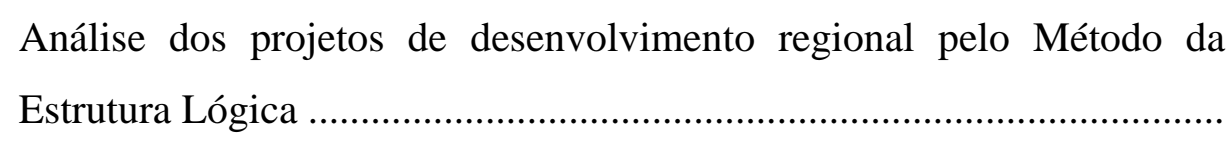 \\
\hline 2.2 & Estudos de desenvolvimento econômicos para os municípios lindeiros .. \\
\hline 2.2 .1 & 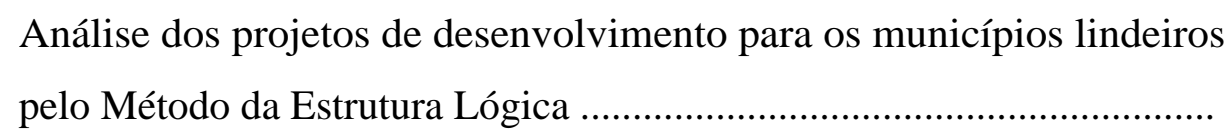 \\
\hline 2.2 .2 & Aspectos importantes sobre o desenvolvimento de municípios lindeiros \\
\hline 3 & CONSIDERAÇÕES SOBRE O DESENVOLVIMENTO DO ESTADO \\
\hline & DE SÃO PAULO . \\
\hline
\end{tabular}

Página viii

3.1 Crescimento, desenvolvimento econômico e regional ............................. 47

3.1.1 Os modelos de crescimento econômico e os estoques de capitais ............. 47

3.1.2 Crescimento e desenvolvimento econômico ......................................... 56

3.1.3 Desenvolvimento regional ................................................................ 72

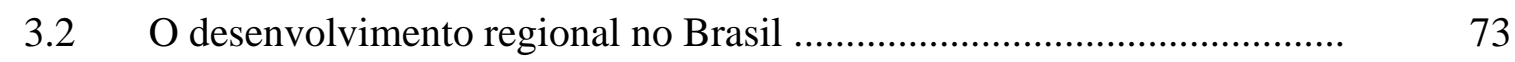

3.3 A questão do desenvolvimento no Estado de São Paulo .......................... 88 
Página

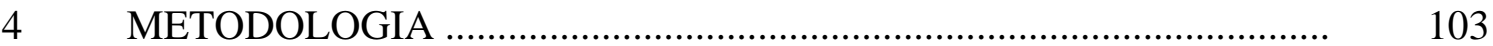

4.1 Análise pelo método de Componentes Principais .................................. 108

$5 \quad$ RESULTADOS E DISCUSSÃO ….................................................... 113

5.1 Resultados dos Componentes Principais .............................................. 113

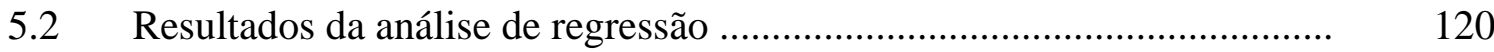

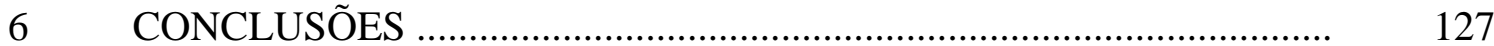

Anexo: ÁREA DO PROJETO CALHA E SUAS SUB-REGIÕES ..................... 131

REFERÊNCIAS BIBLIOGRÁFICAS ….................................................... 133 


\title{
DESENVOLVIMENTO DO VALE DO TIETÊ-PARANÁ: UM ENFOQUE DE ESTOQUES DE CAPITAIS
}

\author{
Autor: ELAINE MENDONÇA BERNARDES
}

Orientador: Prof. FERNANDO CURI PERES

\section{RESUMO}

O propósito geral deste estudo foi identificar quais fatores estariam limitando o do Vale do Tietê-Paraná. Os planos e projetos enfatizam o estoque de capital físico. Como a ênfase nesse estoque esgotou-se na literatura, as atenções voltaram-se para outras formas de capital. Diante disso, os objetivos específicos foram: (1) avaliar as alternativas propostas para os municípios do Vale do Tietê-Paraná expressas nos projetos e planos para a região; (2) analisar a importância dos estoques de capitais para o desenvolvimento dos municípios paulistas lindeiros aos rios Tietê-Paraná, e (3) verificar possíveis diferenças, entre os fatores determinantes do desenvolvimento, existente entre esses municípios e os outros municípios do Estado. Detectou-se, através do Método da Estrutura Lógica, inconsistência nos planos e projetos existentes para o Vale. Quanto aos estoques de capitais, este estudo utilizou a metodologia dos Componentes Principais para reduzir o número de variáveis levantadas inicialmente para representar os cinco estoques de capitais: natural, físico, financeiro, humano e social. A análise incluiu 625 municípios e criou-se uma variável dummy para diferenciar os lindeiros. Nove fatores são os representativos dos estoques de capitais e foram denominados: capital humano 1 (educação); capital físico; capital social 1 (associativismo); capital humano 2 (saúde); capital financeiro 1 (arrecadação); capital social 2 (desconfiança); capital natural 1 
(terra); capital financeiro 2; capital natural 2 (depreciação).A percentagem da variância total explicada por cada um dos estoques foi: 19,5 (capital humano); 8,3 (capital social); 6,0 (capital financeiro); 5,9 (capital físico), e 4,8 (capital natural). Tomando-se esses fatores como variáveis explicativas, regressões lineares foram ajustadas. As variáveis dependentes em cada uma das três foram: número de empregados per capita, número de estabelecimentos de intermediação financeira e Índice de Desenvolvimento Humano (IDH). Os coeficientes obtidos foram significativos para todos aqueles que entraram na respectiva equação de regressão. O capital natural apresentou o maior coeficiente na regressão para emprego per capita, seguido pelo capital físico, mas a importância do estoque de capital humano é evidenciada pela presença na equação dos dois fatores que o representam. O mesmo ocorreu com o capital fínanceiro. Esses resultados sugerem que os estoques de capital humano e financeiro sejam ambos mais relevantes na explicação da variável dependente emprego per capita. Os estabelecimentos de intermediação financeira per capita estão diretamente relacionados aos seguintes fatores: capital financeiro 1, capital humano 2, capital social 1 e capital social 2. Negativamente relaciona-se a: capital natural 2, capital natural 1 e capital humano 1 . Os valores negativos encontrados para esses três últimos estoques provavelmente deve-se ao grande número de municípios pouco povoados - geralmente localizados em regiões de solos mais pobres e menor escolaridade da população - com pelo menos uma agência bancária. Todos os coeficientes da regressão para o IDH apresentaram sinais conforme o esperado e o capital físico não faz parte da solução encontrada. A variável dummy para lindeiros não apareceu em nenhuma das equações. Conclui-se que não há diferença entre os municípios lindeiros e os outros municípios do estado, quanto ao papel dos cinco estoques de capital no desenvolvimento. 


\title{
DEVELOPMENT FOR THE TIETÊ-PARANÁ VALLEY: FOCUS ON STOCKS OF CAPITAL
}

\author{
Author: ELAINE MENDONÇA BERNARDES \\ Adviser: Prof. FERNANDO CURI PERES
}

\section{SUMMARY}

The aim of this study was to identify which factors would be limiting the Tietê-Paraná valley development. The plans and projects focus on physical capital stock. Once the focus on this capital has been depleted, the focus has shifted to other forms of capitals. Therefore, the main goals were: (1) to evaluate the proposed alternatives for the cities in the Tietê-Paraná valley expressed in the plans and projects for the region; (2) analyze the importance of capital stocks for the development of cities located nearby the Tietê-Paraná rivers, and (3) appoint possible differences, among the determining factors for the development, existing among these cities and other cities in the São Paulo state. It was noted, through the Logical Structure Method, inconsistencies in the existing plans and projects for the region. As for the capital stocks, this study made use of Principal Components Methodology in order to reduce the number of variables initially obtained to represent the five capital stocks: natural, physical, financial, human and social. The analysis included 625 cities and it was established a dummy variable to distinguish the ones located nearby the rivers. Nine factors represent the capital stocks and were denominated: human capital 1 (education); physical capital; social capital 2 (distrust); natural capital (land); financial capital 2; natural capital 2 (depreciation). The percentage of the total variance explained by each stock was: 19.5 (human capital); 8.3 (social 
capital); 6.0 (financial capital); 5.9 (physical capital), and 4.8 (natural capital).Taking theses factors like explicative variables, linear regressions were adjusted. The depending variables in each of the three were: number of employees per capita, number of intermediate financial establishments and Human Development Index (IDH). The coefficients obtained were significant for those variables which were addressed in the respective regression equation. The natural capital showed the highest coefficient in the employment regression per capita, followed by the physical capital, however the importance of human capital stock is evidenced by its presence in the equation of the two factors which represent it. The same happened with the financial capital. These results suggest that the stock of human and financial capital be both more relevant in the explanation of the of the depending employment variable per capita. The intermediate financial establishments per capita are directly related to the following factors: financial capital 1, human capital 2, social capital 1 and social capital 2. Negatively, it relates to: natural capital 2, natural capital 1 and human capital 1 . The negative values found in these three last stocks are probably due to the large number of low populated cities generally found in regions of poorer soil and lower education levels of population having at least one bank agency. All the regression coefficients for the IDH show signals according to what was expected and the physical capital is not part of the solution found. The dummy variable for the cities located nearby the rivers was not found in any of the equations. It is concluded, then, that there is no difference among the cities located nearby the rivers and the other cities of the state, regarding the role of the five capital stocks in the development. 


\section{INTRODUÇÃO}

\subsection{Definição do problema e objetivo geral do estudo}

A análise do desempenho econômico do Estado de São Paulo, nos últimos anos, foi menor que o esperado e as desigualdades regionais persistiram. Nos quinze anos decorridos entre 1980 e 1994, a expansão acumulada do PIB paulista foi de 16,9\% contra um crescimento da população de 32,9\%, gerando queda na renda per capita de $11,8 \%$ no período (Seade, 1994). ${ }^{1}$ Quanto às desigualdades regionais em relação ao desenvolvimento, além do conhecido atraso do Vale do Ribeira, há outros sérios problemas em regiões do Oeste do estado. As regiões administrativas de São José do Rio Preto, Araçatuba, Presidente Prudente e Marília, em conjunto, continuam perdendo importância relativa, em termos de valor da transformação industrial no conjunto estadual. Antes de atingir o oeste paulista, a atividade industrial teria se direcionado aos estados vizinhos, principalmente Mato Grosso do Sul e Paraná (Hespanhol, 1996). Assim, ao contrário das "ilhas de prosperidade" do estado, uma extensa área do território paulista permanece atrasada.

As primeiras tentativas de explicação para o desenvolvimento desigual entre as regiões consideravam o capital natural como determinante, mas esta variável vem perdendo gradativamente o poder explicativo com o avanço tecnológico. É ilustrativo lembrar as enormes diferenças no estoque deste capital existentes entre o Japão e os países do Leste Europeu. Fosse determinante aquele estoque de capital, obviamente a

\footnotetext{
${ }^{1}$ Para os dez anos seguintes, seria fácil imaginar o Estado de São Paulo dobrar seu PIB, afirmou, exageradamente, Stefan Matzinger, no prefácio à Edição Brasileira de "O fim do Estado-nação", publicado em 1999 (Ohmae, 1999). Seu objetivo era despertar o leitor para a necessidade de se enxergarem com clareza as diferenças quanto ao potencial econômico existente no País.
} 
ordenação desses países, quanto ao grau de desenvolvimento, desfavoreceria o Japão. Mesmo com o reduzido poder explicativo dessa variável, um recurso natural, o rio Tietê, será tomado como referência para uma discussão introdutória sobre capital natural em São Paulo.

Numa aproximação bastante grosseira, o rio Tietê seria uma linha divisória quanto ao nível de desenvolvimento do estado. Ao norte, o desenvolvimento (representado basicamente pela região de Ribeirão Preto e por São José do Rio Preto), enquanto as regiões mais atrasadas ficam ao sul. É importante observar que nem mesmo as regiões mais pobres do estado o são, de fato, em recursos naturais, quando comparadas a outras do País. O Vale do Rio Tietê, por exemplo, possui topografia que favorece a mecanização em grandes extensões, distribuição de chuvas favorável à agricultura, com algumas limitações contornáveis através da utilização dos fartos recursos fluviais. O solo, embora não seja o mais fértil do estado, apresenta, em geral, um problema facilmente corrigível: a acidez. Evidentemente, em alguns trechos, há baixa fertilidade do solo, acentuada inclusive pelo mau uso deste. Ainda assim, são áreas cujos custos de recuperação provavelmente ainda são inferiores àqueles necessários para elevar a produtividade de outros, por exemplo, localizados na região Centro Oeste do Brasil. Logo, diferenças nos estoques de capital natural seriam, provavelmente, insuficientes para explicar o desenvolvimento desuniforme do Estado de São Paulo.

Duas formas de capital foram posteriormente incorporadas aos estudos econômicos e, ainda hoje, são bastante enfatizadas nas discussões sobre política econômica: o capital físico e o capital financeiro. Durante anos, os esforços do País buscando o desenvolvimento foram concentrados na direção do primeiro. Cabe lembrar a opção pelo desenvolvimento via implantação do "parque industrial", desde as décadas de 1930 e 1940, através da transferência de renda do setor agrícola para o industrial. Com o esgotamento desse modelo, a história econômica do Brasil está repleta de exemplos de grandes obras de engenharia, ou, em outras palavras, da infra-estrutura 
destinada a promover o desenvolvimento. Para tanto, buscou-se o capital financeiro no mercado internacional.

O capital financeiro possui grande importância para o desenvolvimento, dada sua escassez justamente nos países menos desenvolvidos. O Brasil não é exceção, tendo apresentado baixa taxa de poupança interna, associada, em alguns períodos de sua história recente, a dificuldades para atrair o capital internacional. Não cabe aqui discutir os motivos do baixo volume de poupança interna (em geral, associado ao volume ou distribuição da renda), mas chamar a atenção para a conseqüente dependência dos recursos externos no desenvolvimento do País.

Há uma correspondência entre o período de recursos financeiros acessíveis aos países menos desenvolvidos e os investimentos realizados em capital físico no Brasil, destacando-se a construção de hidrelétricas que, em São Paulo, deu-se em regiões menos desenvolvidas. As hidrelétricas desse período localizam-se no Extremo Noroeste e no Pontal do Paranapanema. É o caso das hidrelétricas de Jupiá (de 1968), Ilha Solteira (de 1973) e Promissão (de 1975). Passado o período das grandes obras da década de 1970, as hidrelétricas continuaram a ser construídas em regiões problemáticas do estado. Duas delas estão no Pontal do Paranapanema (Rosana e Porto Primavera) e outra no Extremo Noroeste (Três Irmãos).

Além das obras necessárias para a construção de hidrelétricas, nas quais inclui-se até mesmo a construção de cidades, encontra-se outro volumoso investimento em capital físico ao longo de regiões bastante problemáticas do estado: a hidrovia Tietê Paraná. A Companhia Energética de São Paulo (CESP) apontava a hidrovia, como “o principal fator de industrialização e desenvolvimento do turismo no interior paulista e de reordenamento da matriz de transportes da região Centro-Leste, permitindo a multimodalidade em larga escala, com grande ganho em competitividade para os produtos brasileiros" (CESP, 1997a, p.5). Evidentemente, a segunda parte dessa afirmação parece suficiente para demonstrar a importância de tal obra, mas o interesse 
aqui reside especificamente na primeira parte da afirmação, ou seja, sobre a hidrovia e o potencial de desenvolvimento do Vale do Tietê.

A área abrangida pela hidrovia é bastante ampla e com diferenças que incluem tipos de solos e graus de desenvolvimento sócio-econômico, passando pela questão fundiária. ${ }^{2}$ De acordo com informações publicadas em 1997 pela CESP, estudos econômicos sobre a hidrovia e a região "impactada" revelam que o polígono formado por São José do Rio Preto, Ribeirão Preto, Campinas, Sorocaba e Marília é a região mais adequada para a fixação de indústrias de elevada tecnologia (CESP, 1997a). Contudo, entre esse polígono e a região central do Brasil, que se beneficiaria do escoamento da produção a custos mais baixos, há, em território paulista, uma vasta área cortada pela hidrovia que, conforme já mencionado, vem encontrando grande dificuldade para desenvolver-se.

Considerando-se que investimentos em capital físico ainda não surtiram o resultado esperado, questiona-se sobre quais fatores estariam limitando o desenvolvimento de regiões do Vale do Tietê. Se dependesse apenas dessa forma de capital, grande parte do Estado de São Paulo relativamente atrasada estaria mais desenvolvida, mas expectativas de desenvolvimento geradas por investimento em capital físico nem sempre surtiram o efeito esperado. Por exemplo, pode-se indicar as tentativas mencionadas por Hespanhol (1996) ao estudar a região de Andradina, no extremo noroeste paulista. A primeira tentativa de ocupação dessa parece remontar à antiga colônia militar de Itapura, SP, às margens do rio Paraná. De lá para cá, há pelo menos outros dois empreendimentos cujos resultados frustraram as expectativas: construção da Estrada de Ferro Noroeste do Brasil e a construção das usinas hidrelétricas. Hespanhol referiu-se à primeira, afirmando que esta não provocou o desencadeamento do processo de ocupação da Região de Andradina, SP. Quanto à construção das Usinas Hidrelétricas de Jupiá e Ilha Solteira (no rio Paraná), nos anos de 1960 e 1970, e de Três Irmãos (rio

\footnotetext{
${ }^{2}$ Em função dessas diferenças, a rigor não se poderia chamar a grande área abrangida de "região", mas isto seria objeto de uma discussão mais ampla que foge ao escopo desta introdução. Ao longo da realização da pesquisa, essa discussão será retomada.
} 
Tietê), a partir do ano de 1980, o autor atribuiu o fracasso das expectativas à falta de adoção de planos integrados que catalisassem os aspectos positivos dos empreendimentos e amenizassem os negativos gerados pelo término das obras. Entretanto, é bastante provável que o insucesso dos efeitos desenvolvimentistas das hidrelétricas possa ser resultante da carência de um ou mais fatores ou estoques de capital.

Do ponto de vista do chamado "desenvolvimento sustentável", o Vale do Tietê possui, de acordo com o Departamento Hídrico da Secretaria de Transportes do Estado de São Paulo, os recursos fundamentais para o desenvolvimento (água, energia e transporte barato) e seria a região paulista que melhor responderia a estímulos para o desenvolvimento. ${ }^{3}$ Como explicar, então, o fato de os municípios "lindeiros", ou seja, aqueles "de frente" para o rio constituírem uma das regiões mais pobres do estado? A explicação para a persistência da necessidade de desenvolver a região do Vale do Tietê torna-se mais complexa, dado o volume de capital físico existente na forma de obras para aproveitamento dos rios. O insucesso dos efeitos desenvolvimentistas das hidrelétricas poderia ser resultante da permanência de alguns "pontos de estrangulamento" ao desenvolvimento da região. Esses pontos poderiam existir também em outras localidades ao longo da hidrovia Tietê-Paraná, tornando fundamental a necessidade de "mapeá-los" e considerá-los nas propostas vinculadas à hidrovia a fim de se obter maior retorno sobre os investimentos realizados.

As análises de crescimento econômico apresentavam, no passado, um "resíduo" não explicado pelas três formas de capital (natural, físico e financeiro) que foi explicado, parcialmente, pelo que hoje se conhece por capital humano. Este tipo de capital está diretamente associado à extensão, assistência técnica, saúde e educação, ou seja, a aspectos que elevem a produtividade do trabalho. Outras variáveis mais freqüentemente a ele associadas são a cultura, valores da sociedade e a própria língua. A

3 Observação feita por Osvaldo Rosseto, diretor do Departamento Hidroviário, da Secretaria de Transportes do Estado de São Paulo, na XII Reunião da Hidrovia Tietê-Paraná, realizada em 15/06/2000, em Piracicaba, São Paulo. 
disponibilidade desse capital esclareceu o crescimento econômico de países pobres em outros recursos. Dentre esses países, o mais citado na literatura é o Japão, dadas suas limitações em capital natural, já mencionada, e às quais se pode adicionar a imensa destruição de capital físico nos anos da Segunda Grande Guerra. A escassez do capital humano também explica, muitas vezes, o subdesenvolvimento de países, regiões ou setores de uma mesma economia. A transferência desse capital entre os setores da economia, de acordo com Schuh (1998), leva as atividades econômicas urbanas a se beneficiarem ao receberem capital humano oriundo do meio rural, através do processo migratório. Esse processo, segundo o autor, pode ser altamente seletivo em favor do capital humano, atraindo-o para o desenvolvimento de atividades econômicas fora de áreas rurais e contribuindo para elevar o rendimento das atividades urbanas "como uma dádiva". Se o mesmo raciocínio for aplicado ao Estado de São Paulo em relação a suas diferentes regiões (e não aos diferentes setores), verifica-se que a redução de população (por exemplo, da região de Andradina entre os anos de 1970 e 1980), ou o baixo crescimento de outras, sugere evasão de capital humano, "presenteando" outras regiões que estariam elevando o rendimento de suas atividades econômicas.

O bom aproveitamento de possíveis alternativas para desenvolver a região do Vale do Tietê requer a identificação, avaliação da disponibilidade dos fatores existentes e a verificação de limitações causadas pelo baixo estoque de algum ou alguns

deles. É possível que a existência de fatores limitantes às oportunidades prejudiquem o andamento de futuras tentativas de investimento associadas às obras de aproveitamento dos rios. A fim de viabilizar-se o aproveitamento de alternativas de investimentos relacionadas à hidrovia Tietê - Paraná, é importante que se identifique e avalie esses fatores. Realizar esta identificação, com enfoque nos estoques de capitais nas diferentes formas definidas pela literatura, é o propósito geral deste trabalho.

\subsection{Justificativa e objetivos específicos}

A região impactada pela hidrovia Tietê-Paraná compreende uma vasta área do território nacional. Os números impressionam pela sua dimensão. São cerca de 1.200 
$\mathrm{km}$ percorridos pelo rio Tietê até desembocar no rio Paraná, que faz a divisa de cinco estados brasileiros: Goiás, Mato Grosso do Sul, Paraná, São Paulo e Minas Gerais. Além desses estados, o rio Paraná faz fronteira com o Paraguai. A área de "macroinfluência econômica da Hidrovia Tietê-Paraná", de acordo com a Companhia Energética de São Paulo (CESP) é de 76 milhões de hectares, cerca de 9\% do território brasileiro, incorporando quatro dos cinco maiores estados agrícolas do país, "impactando" diretamente 206 municípios. Infelizmente, o critério utilizado para delimitar a área não foi divulgado no trabalho em questão. Mais relevante ainda para justificar estudos econômicos voltados à região é a população local que a CESP afirma, na publicação de 1997, estar em 50 milhões de habitantes. A maioria dessa população vive no Estado de São Paulo e isto torna ainda mais relevante estudos sobre a região paulista "cortada" pela hidrovia.

Dada sua dimensão, as características da região do Vale do Tietê não são homogêneas. Mesmo ao se considerar apenas o Estado de São Paulo, é preciso ter em mente que o desenvolvimento não se deu por igual na área abrangida pela hidrovia. A região localizada no extremo Noroeste paulista, por exemplo, vem mantendo-se relativamente atrasada em relação a outras regiões do estado e do país ocupadas mais recentemente. Particularmente a região de Andradina "não conseguiu atrelar-se de forma expressiva a nenhum tipo de dinâmica regional constatada em outras regiões com perfil semelhante" (Hespanhol, 1996, p. xvii). A agricultura, baseada em lavouras tradicionais, não se modernizou como as regiões de Campinas, Ribeirão Preto, ou mesmo no Paraná e no Centro-Oeste do país. Sua principal atividade, a produção de carne bovina, não se desenvolveu significativamente. Com isso, a participação dessa região no Valor da Produção Agropecuária do estado é de apenas 2,16\%, conforme observado nos dados apresentados por Donadelli et al. (1997), utilizando dados do projeto LUPA (Levantamento Censitário de Unidades de Produção Agrícola do Estado de São Paulo). ${ }^{4}$ Assim, pode-se notar que, dentro da região impactada pela hidrovia, os problemas não são os mesmos. As diferenças entre os municípios que compõem a região podem ser 
sutis, mas é necessário conhecê-las melhor a fim de não se incorrer em generalizações equivocadas em futuros planos de desenvolvimento regional.

A região abrangida pela hidrovia Tietê-Paraná apresenta grande necessidade de geração de empregos para a mão-de-obra local. No trecho paulista, com o término das obras das hidrelétricas, a situação se agravou. A construção do Complexo Hidrelétrico de Urubupungá (Jupiá, Ilha Solteira e Três Irmãos), a partir dos anos de 1960, provocou fortes impactos na região, não promovendo, entretanto, o desenvolvimento. Como se tratava de um empreendimento de caráter temporário, a partir do término das obras, as empreiteiras demitiram operários e a população tem migrado para outras regiões. A título de ilustração, a redução da população da região de Andradina entre os anos de 1970 e 1980 foi de 13\%, e entre, 1980 e 1991, o crescimento foi de apenas 10\%, contra 24,5\% no Estado de São Paulo (Hespanhol, 1996).

Há sérios problemas sociais freqüentemente associados a questões agrárias nas proximidades dos rios. Os conflitos no campo são bastante antigos e persistem. Operários demitidos e pequenos produtores rurais que viviam em áreas inundadas pelos lagos aliaram-se a outros "sem terras" da região e oriundos de outras regiões e pressionam a sociedade para encontrar soluções. Em alguns trechos, a situação tornou-se mais grave em função da existência de fazendas cujos títulos de propriedade são contestáveis. Surgiram, como resposta a essas questões sociais, os assentamentos e reassentamentos da CESP, INCRA (Instituto Nacional de Colonização e Reforma Agrária) e Instituto de Terras de São Paulo (ITESP). Essas "respostas", entretanto, estão ainda bastante aquém das necessidades. A não-industrialização da região pode ajudar, em parte, a explicar as filas de "sem terra". Esse grave problema social poderia ser associado, à primeira vista, à expulsão da mão-de-obra rural pelo processo de modernização da agricultura. Entretanto, sabe-se que esse processo não ocorreu em extensas áreas do oeste do Estado de São Paulo, por exemplo, na região de Andradina, já

\footnotetext{
${ }^{4}$ PINO, F.A. (Org.). Levantamento censitário de unidades de produção agrícola do Estado de São
} Paulo. São Paulo: IEA/ CATI/ SAA, 1997. 
mencionada. Logo, há outros fatores influenciando a geração de emprego e renda que precisam ser esclarecidos.

A carência de estudos que verifiquem a viabilidade de investimentos na região do Vale do Tietê-Paraná torna mais provável o mau uso dos recursos (inclusive públicos). A falta de uma visão mais ampla, que pode ser gerada a partir de estudos sobre desenvolvimento regional, leva o poder público a atuar, muitas vezes, diretamente no setor produtivo e a desgastar-se na chamada "guerra fiscal" entre os estados e municípios. Não tem sido rara a disputa entre municípios pela instalação de indústrias ao longo da hidrovia. Essa concorrência seria bastante saudável se não significasse, muitas vezes, uso ineficiente de recursos regionais existentes.

Um estudo que identifique os fatores limitantes ao bom aproveitamento das oportunidades que surgiriam com a hidrovia Tietê-Paraná permite o direcionamento de recursos visando à superação desses fatores. Dessa forma, este trabalho pode colaborar para detectarem-se as necessidades de medidas complementares para a implantação de projetos de investimentos ao longo do Vale. A partir do momento em que se identifica os fatores mais importantes que limitam o desenvolvimento da região, o poder público pode melhor direcionar seus recursos e com isso colaborar para atrair mais capital privado. A adoção de medidas complementares pode ser necessária, mesmo para a implantação dos projetos mais viáveis. Tais medidas poderão estar relacionadas a incentivos fiscais, treinamento de mão-de-obra, etc. Futuras discussões políticoadministrativas regionais sobre aplicação de recursos poderiam beneficiar-se deste estudo que procurou indicar alguns caminhos e, até mesmo, a direção mais adequada para o desenvolvimento da região impactada pela hidrovia Tietê Paraná. Especificamente, os objetivos são:

1) avaliar as alternativas propostas para os municípios do Vale do TietêParaná expressas nos projetos e planos para a região;

2) analisar a importância dos estoques de capitais para o desenvolvimento dos municípios paulistas lindeiros aos rios Tietê-Paraná, e 
3) verificar possíveis diferenças, entre os fatores determinantes do desenvolvimento, existente entre os municípios paulistas lindeiros aos rios Tietê-Paraná e os outros municípios do Estado. 


\section{OS PROJETOS PARA O VALE DO TIETÊ-PARANÁ}

Dada a ênfase às possibilidades de desenvolvimento do Vale do Tietê-Paraná associadas às obras relativas à instalação das hidroelétricas e implantação da hidrovia Tietê-Paraná, serão discutidos neste capítulo planos e projetos para essa região que, de certa forma, se associam a essas obras. Além desses projetos, há estudos acadêmicos voltados para o Vale que serão apresentados neste capítulo para complementam a discussão sobre a região enfocada neste estudo.

Os projetos formalmente elaborados para a região do Vale do Tietê-Paraná foram analisados através do método da Estrutura Lógica. Esse método, desenvolvido pela Management Systems International ${ }^{5}$, consiste em representar um projeto na forma de uma matriz $4 \times 4$, cujos elementos permitem a análise do projeto em questão através da utilização de critérios relacionados ao método científico, à análise de sistemas e ao ponto de vista da gerência de programas. O método da Estrutura Lógica pode ser usado para planejamento, elaboração do projeto em si, implementação e avaliação de projetos. Esse método fornece uma estrutura para estabelecer prioridades e determinar resultados e atividades pretendidos pelo projeto. Pode ainda fortalecer as bases para que se avalie a efetividade, eficiência e relevância de um projeto (Jackson, 1998).

A colaboração do método científico, na Estrutura Lógica, consiste na introdução da incerteza na elaboração do projeto, ou seja, as informações contidas no projeto devem explicitar os fatores incertos, os pressupostos. A necessidade de se definir um sistema maior no qual o projeto está inserido é uma exigência da análise de sistemas.

5 MANAGEMENT SYSTEMS INTERNATIONAL Estrutura lógica: um guia para gerentes para planejar e avaliar projetos de forma científica. Trad. de Francisco B. Tancredi. s.n.t. 
O terceiro ponto de vista incorporado simultaneamente na metodologia da Estrutura Lógica (o ponto de vista do gerenciamento) estabelece que, se o objetivo do gerenciamento é atingir determinados resultados, espera-se que os gerentes sejam responsáveis pelos mesmos. Tal responsabilidade diz respeito a três níveis hierárquicos básicos: Insumos, Produtos e Propósito. Como o próprio nome diz, os insumos são consumidos para gerar os produtos (os resultados a serem atingidos pelos gerentes) e possibilitam atingir o nível seguinte (o propósito, a razão de ser do projeto). A utilização da Estrutura Lógica possibilita que a relação "se A então B" seja verificada. Por exemplo, no nível mais baixo de objetivos (onde estão os insumos do projeto), tem-se que: se Insumos, então Produtos. No segundo nível, se Produtos, então Propósitos. No nível mais elevado da hierarquia gerencial (acima do propósito do projeto), a mesma relação indica que: se Propósitos, então Fim (o último nível da hierarquia que significa a especificação completa do sistema ao preencher a exigência da análise de sistemas).

De acordo com Jackson (1998), na realidade, há vários métodos de Estrutura Lógica, mas há um método genérico que pode ser adaptado às necessidades do usuário ou da agência financiadora do projeto. Usualmente, a Estrutura Lógica consiste, segundo o autor mencionado, em uma fase de análise e de planejamento com três passos cada fase, conforme Quadro 1:

\begin{tabular}{|c|c|}
\hline Fase de Análise & Fase de Planejamento \\
\hline Análise dos Problemas & Estrutura Lógica \\
\hline Análise de Objetivos & Cronograma de Atividades \\
\hline Análise de Estratégias & Insumos e Cronograma de custos \\
\hline
\end{tabular}

Quadro 1 - Fases do método da Estrutura Lógica.

Fonte: Jackson (1998)

Jackson (1998) define sucintamente cada um dos passos apresentados no Quadro 1 e apresenta os pontos fracos e os requisitos para se desenvolver uma Estrutura Lógica. Neste estudo em particular, dentre os objetivos definidos, encontra-se a 
avaliação de alternativas de desenvolvimento, ou seja, trata-se de projetos já existentes e não a elaboração de um novo projeto. Assim, detalhar os primeiros passos do Quadro 1 não se faz necessário. Entretanto, é importante para o entendimento do potencial do método para a avaliação de projetos que se observe que, quando desenvolvido, seguindo-se os passos do Quadro 1, um projeto preenche a matriz de Estrutura Lógica indicada no Quadro 2. A matriz representada nesse quadro seria elaborada a partir da análise estratégica (último passo da fase de análise) e assim daria início à fase de planejamento do projeto:

\begin{tabular}{|c|c|c|c|}
\hline Objetivos/Atividades & $\begin{array}{c}\text { Indicadores } \\
\text { Objetivos }\end{array}$ & $\begin{array}{c}\text { Meios de } \\
\text { Verificação }\end{array}$ & Pressupostos \\
\hline $\begin{array}{c}\text { Objetivos Globais ou } \\
\text { Fim }\end{array}$ & "n" Indicadores & $\begin{array}{c}\text { Meios de verificação } \\
\text { dos “n” indicadores }\end{array}$ & "k" pressupostos \\
\hline Propósito do Projeto & "x" indicadores & $\begin{array}{c}\text { Meios de verificação } \\
\text { dos “x" indicadores }\end{array}$ & "l" pressupostos \\
\hline Resultados ou Produtos & "y" indicadores & $\begin{array}{c}\text { Meios de verificação } \\
\text { dos "y" indicadores }\end{array}$ & "m" pressupostos \\
\hline Atividades ou Insumos & "z" indicadores & $\begin{array}{c}\text { Meios de verificação } \\
\text { dos "z" indicadores }\end{array}$ & "p" pressupostos \\
\hline
\end{tabular}

Quadro 2 - A matriz de Estrutura Lógica.

Fonte: Adaptado de Jackson (1998)

Se um projeto for desenvolvido segundo a Estrutura Lógica, os objetivos, propósitos, produtos e atividades serão transcritos da "árvore de estratégia" produzida na análise de estratégias (último passo da fase de análise) para as colunas e linhas da matriz de Estrutura Lógica. A finalidade de se especificar os pressupostos é identificar fatores externos que afetarão o sucesso do projeto. Uma vez identificado, de acordo com ITAD $(1996)^{6}$, citado por Jackson (1998), eles são estabelecidos em termos da situação desejada. Em outras palavras, o projeto estabelece que, uma vez atingido um nível hierárquico e ocorrendo a situação desejada (o pressuposto), outro nível do projeto é alcançado.

${ }^{6}$ ITAD The logical framework approach: a project management tool. s.ed., 1996. 
Sobre os indicadores e seus respectivos meios de verificação, Jackson (1998) apresenta as características desejadas. Cada indicador deve ser objetivamente verificável e estabelecido segundo alguns critérios: a) deve ser mensurável (tanto em termos quantitativos quanto qualitativos); b) deve ser exequíivel (em termos financeiros, de equipamentos, estratégias e tempo); c) deve ser relevante e preciso (ou seja, deve refletir o que se está tentando medir de modo acurado); d) deve ser sensível (o que significa ser capaz de captar mudanças ao longo do período de tempo em questão); e e) ser capaz de fornecer informação em tempo hábil. Uma vez estabelecidos os indicadores, as fontes de informação e os meios de coleta devem ser estabelecidos, ou seja, os meios de verificação para cada indicador. O meio de verificação deve testar se o indicador ao qual está associado pode ou não ser realisticamente mensurado dentro de limites razoáveis de tempo, dinheiro e esforço. Cada meio de verificação deve especificar o formato na qual a informação estará disponível, quem a fornecerá e com que regularidade esta será fornecida (ITAD, op. cit.).

A utilização do método da Estrutura Lógica na avaliação de projeto utiliza-se das informações contidas no próprio projeto ao invés de fontes primárias de dados para a fase de análise. Conforme ITAD (op. cit.), a Estrutura Lógica é um instrumento poderoso para análise de projeto. O mesmo autor apresenta uma seqüência para avaliação de projetos por esse método. Nela, as inconsistências da elaboração do projeto são verificadas em: problemas não endereçados pelos objetivos, objetivos para os quais nenhum problema correspondente foi identificado e diferenças em relações entre causaefeito/meios-fins e entre a "árvore problema" e a "árvore objetivo". A Estrutura Lógica pode, de acordo com Jackson (1998), ser utilizada também para projetos que não tenham sido elaborados utilizando-se de tal estrutura. Nesse caso, a fase de análise deve ser encurtada, usando-se os objetivos do projeto e desenvolvendo-se uma matriz de Estrutura Lógica. Esse será o procedimento adotado neste trabalho, considerando-se que se sabe, de antemão, que a Estrutura Lógica não foi utilizada na elaboração dos projetos. 


\subsection{Estudos regionais de desenvolvimento para o Vale do Tietê-Paraná}

Os planos de desenvolvimento relacionados ao aproveitamento das obras dos rios Tietê e Paraná podem ser divididos entre aqueles que abordam a região como um todo e estudos voltados a municípios específicos. Dentre os estudos que abordam uma região ampla, encontram-se o Plano de Desenvolvimento Turístico da Hidrovia TietêParaná (São Paulo, 1986), o Projeto Calha (CITP, 1994), o Plano de Fomento (CESP, 1996) e o Master Plan (ADTP, 1996). Com exceção desse último, todos foram elaborados por técnicos do estado que atuavam nas secretarias e na CESP ou, no caso do Calha, do Consórcio Intermunicipal Tietê-Paraná (CITP).

O Plano de Desenvolvimento Turístico da Hidrovia Tietê-Paraná foi, provavelmente, a primeira tentativa de se abordar a questão do desenvolvimento do turismo no Vale de maneira regional e não apenas em projetos municipais isolados. Surgiu da necessidade de se atender a solicitações das prefeituras municipais ao governo estadual, ainda na primeira metade dos anos de 1980. A tentativa de resposta a tais solicitações resultou no lançamento do Plano em 1984, pela Secretaria de Estado dos Negócios de Esportes e Turismo (SET). Em 1985, a SET firmou convênio com a CESP para "estudar o uso das margens dos lagos formados pelas barragens do rio Tietê", visando ao aproveitamento para o lazer e o turismo convencional e social (São Paulo, 1986, p.5). Em 1986, a Empresa Brasileira de Turismo (EMBRATUR) passou a integrar o convênio.

A partir do Plano de Desenvolvimento Turístico da Hidrovia, foi detectada a necessidade de se conhecer melhor a região do Vale do Tietê-Paraná, o que estimulou o surgimento do projeto Calha. Trata-se do estudo regional mais bem elaborado dos quatro encontrados para o Vale. No projeto Calha, oitenta e seis municípios paulistas foram agrupados em quatro sub-regiões. A área de atuação foi dividida de acordo com o papel a ser cumprido no processo de planejamento, de forma que as regiões têm uma relação com objetivos a serem atingidos. Assim, a sub-região 1 (a do estado, lindeira ao rio Paraná) foi denominada Integração, e, a partir dela, em direção à cidade de São Paulo, as 
sub regiões receberam os nomes de Dinamização, Modernização e Reprogramação. ${ }^{7}$ As principais características das sub-regiões são apresentadas em CITP (1994) bem como as diretrizes gerais do projeto.

A última tentativa de planejamento governamental para o Vale foi o Plano de Fomento, elaborado posteriormente ao Calha, de acordo com CESP (1996), inclui os cento e oito municípios localizados em uma área considerada de influência da Hidrovia Tietê-Paraná. Neste plano, a área de influência foi dividida em quatorze regiões hidroviárias. A diferença no número de municípios nos dois estudos (Projeto Calha e Plano Fomento) é resultado dos critérios considerados em suas elaborações. O Projeto Calha considerou os municípios efetivamente lindeiros e incluiu outros que sofrem ou produzem alterações significativas na região de influência direta da hidrovia, além de considerar a extensão desta até Piracicaba. Com isso, chegou a oitenta e seis municípios localizados desde Itu e Salto, no rio Tietê, e de Piracicaba, no rio Piracicaba, até a Foz do Tietê. Na margem paulista do rio Paraná, os municípios incluídos vão desde Indiaporã, no rio Grande, até Teodoro Sampaio e Rosana, às margens do rio Paranapanema. O Plano Fomento ampliou mais ainda o número de municípios para um total de 108, que foram divididos em 14 regiões hidroviárias de fomento.

O número de municípios incluídos no Plano de Fomento foi resultado da distância considerada a partir da hidrovia. Esse plano abrangeu municípios existentes até $150 \mathrm{~km}$ da hidrovia para incluir aqueles considerados polarizadores. Com essa expansão, o número de municípios totalizou 108. Evidentemente, todos eles poderiam ser beneficiados pela hidrovia, mas, a rigor, todo o País o seria, principalmente através da diminuição nos custos de transportes. Em termos de uma proposta para atuação governamental, talvez o número de municípios não seja alto, mas, para se avaliar o efeito da hidrovia (e de outras obras nos rios) no desenvolvimento regional, é interessante que se reduza a áreas mais próximas às margens dos rios. À distância considerada no Plano de Fomento e principalmente a convergência de outros fatores (como, por exemplo, as indústrias já instaladas na região de Campinas) nas cidades

\footnotetext{
${ }^{7}$ Mapa encontra-se em Anexo.
} 
polarizadoras (e não lindeiras) inviabilizaria a análise que esta pesquisa se propõe a realizar.

Além dos três planos governamentais de desenvolvimento, há o Master Plan, um estudo realizado pelo setor privado apresentado pela Agência de Desenvolvimento Tietê-Paraná (ADTP, 1996) e que, ao contrário do que o nome indica, consiste em uma revisão dos projetos existentes na região e não em um único e novo plano. São apresentados resumos de projetos agrupados por Setores de Infra-estrutura ou sob a denominação genérica de "Outros projetos e Oportunidades". Os Setores denominados de Infra-estrutura no Master Plan são: energia, transporte, telecomunicações e saneamento ambiental. Para os propósitos desta pesquisa, o texto deixa muito a desejar, uma vez que menciona a existência de projetos, mas, de fato, não os apresenta devidamente. Além de excessivamente resumida a apresentação dos projetos, o texto remete-se muitas vezes a outros textos não publicados.

Um resumo extremamente sucinto sobre a hidrovia Tietê-Paraná está incluído no Master Plan, no item destinado a tratar dos projetos para o setor transporte. Na realidade, o projeto mencionado é para construção e operação de frotas e terminais na hidrovia Tietê-Paraná. Embora os dados apresentados não permitam extrair as informações necessárias para o preenchimento de uma matriz de Estrutura Lógica, é possível detectar um forte pressuposto para a viabilidade da hidrovia que consiste na concretização do projeto de Desenvolvimento do Vale do Piracicaba. Além dos resumos sobre a hidrovia e sobre o Projeto para o Vale do Piracicaba, os projetos e oportunidades mencionados para turismo e agribusiness são os únicos de maior interesse para este estudo. Quanto às oportunidades associadas ao turismo, o texto é bastante vago e inclui regiões muito distantes do Vale do Tietê-Paraná (como, por exemplo, empreendimentos na cidade de Uberlândia e na Costa Leste do Paraná). Para turismo na hidrovia, o plano admite a necessidade de estudos específicos. Com relação às oportunidades no agribusiness, não há um projeto propriamente dito, mas apenas são enumeradas as atividades econômicas desse setor existentes na ampla região considerada pelos autores, as quais não são devidamente discutidas no estudo. 
Outros projetos mencionados no Master Plan dizem respeito a regiões muito distantes do Vale do Tietê-Paraná ou ainda de potencial de desenvolvimento regional bastante duvidoso. Só para se ter uma idéia, o Master Plan incluiu a privatização do Estádio de Futebol Maracanã e do Complexo Penitenciário do Carandiru, entre os projetos de investimentos na região. Por outro lado, deve ser ressaltado que, nos projetos para Parques Temáticos, o texto sequer menciona a existência de projetos para municípios lindeiros à hidrovia, limitando-se a incluir, para o Estado de São Paulo, parques para as cidades de Valinhos, Ribeirão Preto e Paulínia. Mais uma vez, fica claro a preocupação do texto em demonstrar o potencial da Agência de Desenvolvimento Tietê-Paraná - ADTP, de atuar em quase todo o País e em áreas de investimento bastante diversificadas. Esse interesse ofusca o potencial das obras nos rios para a promoção do desenvolvimento nas localidades onde elas ocorreram e nos arredores que poderiam estar se beneficiando, por exemplo, da navegabilidade dos rios em conseqüência dessas obras.

Apesar das críticas apresentadas ao Master Plan, deve ser ressaltado o mérito em compilar-se informações sobre o Vale Tietê-Paraná, buscando despertar o interesse de empresários para a região e por apresentar uma matriz de apoio à decisão e uma matriz de impactos intersetoriais. A primeira (para verificar a atratividade dos projetos) é apresentada apenas para ilustração do modelo, não sendo possível inferir a importância dos projetos mencionados. Já a matriz de impactos intersetoriais, na qual seria possível obterem-se os efeitos multiplicadores de cada projeto sobre a demanda final de bens e serviços na economia, é apresentada com dados dos projetos agregados por setores. Assim, o "Subsistema Hidroviário", cujo investimento proposto pelo Master Plan seria de R \$2.169.000.000, geraria, por exemplo, no setor de agribusiness, um impacto de $\mathrm{R} \$ 21.088 .000$, de acordo com a matriz apresentada. Considerando-se todos os setores, uma vez realizados os investimentos apresentados no plano, no setor hidroviário, no valor já mencionado, o impacto total seria de $\mathrm{R} \$ 1.273 .810 .000$. Além dos valores em moeda nacional, o quadro também permite verificar a expectativa de geração de empregos para cada subsistema do setor transporte considerado (rodovias 
estaduais, rodovias federais, subsistema portuário, subsistema hidroviário, subsistema aeroportuário e ferrovias e outros projetos de transportes), bem como para os outros setores de infra-estrutura que constam no Master Plan. Com os investimentos propostos para o setor hidroviário, seriam gerados 129.967 empregos, sendo 21.088 no agribusiness. Os dados tiveram origem no volume de investimento proposto pelos projetos apresentados no Master Plan e os impactos calculados a partir da Matriz Insumo-Produto de 1980 do Instituto Brasileiro de Geografia e Estatística (IBGE).

Além do Master Plan, a preocupação em atrair o capital privado para investir no Vale do Tietê-Paraná também está presente no Plano de Fomento. Essa preocupação provavelmente levou à ampliação do número de municípios no Plano Fomento em relação ao Calha e à definição de uma região bastante extensa no Master Plan. Além disso, os dois planos têm um caráter bastante otimista em relação à região que definem. Esse otimismo, em parte, é justificável justamente pela inclusão de municípios que têm se desenvolvido a taxas superiores às médias do estado. Ao incluir a região de Campinas, por exemplo, os dados apresentados no Plano de Fomento tornam a região tão interessante que parece desaparecer a desigualdade regional existente entre o Vale do Tietê-Paraná e as regiões desenvolvidas do Estado de São Paulo (por exemplo, Campinas e Ribeirão Preto). Essa visão otimista está bastante clara no texto, apesar de reconhecer as diferenças entre os municípios polarizadores e alguns lindeiros quanto ao valor agregado e particularmente quanto à arrecadação de ICMS (Imposto sobre a Circulação de Mercadorias e Serviços). Sobre esse imposto, o Plano apresenta a contribuição das Regiões Hidroviárias Polarizadas (19\% do total do estado) e das lindeiras $(5,10 \%)$ e reconhece que a diferença poderia ser ainda mais grave não fosse o ICMS recolhido pela geração hidroelétrica por alguns municípios lindeiros, e, em segundo plano, a existência de usinas açucareiras nas regiões lindeiras. Esses dados, por si só, reforçam a idéia de que a região deve ser mais estudada e comparada com outros municípios quanto aos fatores de desenvolvimento.

Em resumo, as tentativas de planejar o aproveitamento das obras nos rios Tietê e Paraná, para o desenvolvimento, sob uma ótica regional, iniciaram-se no 
Governo Montoro (período 1983-86), e, desde então, três planos governamentais foram elaborados, mas não efetivamente implantados. Além desses planos, o setor privado esboçou um plano para atrair investimentos para a região, mas o interesse foi menor que o esperado, e a Agência de Desenvolvimento do Tietê-Paraná - responsável pelo estudo, embora ainda mantenha este nome e atue no Vale do Tietê-Paraná, tem direcionado seus trabalhos para projetos de infra-estrutura em outras regiões do País. Considerando que os planos não despertaram o interesse esperado, questionam-se as razões para a frustração das expectativas contidas nesses planos. Nesse sentido, tomando-se a Estrutura Lógica como referência metodológica, os projetos regionais mencionados serão analisados a seguir, em busca das respostas.

\subsubsection{Análise dos projetos de desenvolvimento regional pelo Método da Estrutura Lógica}

O texto que gerou a análise do Projeto Calha (CITP, 1994) a ser apresentada permitiu o preenchimento apenas da coluna que resume o projeto (as intenções dele) e a dedução dos indicadores objetivos e meios de verificação correspondentes, nos dois níveis hierárquicos inferiores da matriz de Estrutura Lógica. Na realidade, o texto não é o projeto em si (que não foi encontrado), mas sim a "síntese do relatório técnico entregue em Dezembro de 1993” (CITP, 1994, página de apresentação), ou seja, um documento sobre o cumprimento da primeira fase do projeto. A partir desse documento, elaborou-se o Quadro 3.

De CITP (1994), é possível deduzir que o projeto Calha propôs inicialmente que as informações caracterizadoras das sub-regiões que o compunham fossem devidamente utilizadas para se estabelecerem as diretrizes específicas para cada subregião. Dessa forma, entendeu-se que essas informações foram os insumos. A partir desses insumos, o produto que deveria ser gerado (e de fato o foi) eram as diretrizes específicas para cada sub-região lindeira. Uma vez estabelecidas as diretrizes, o propósito do Projeto, ou seja, a razão de ser do projeto seria o surgimento de um novo

modelo de gestão que operacionalizasse as diretrizes do plano. Esse é o encadeamento 
lógico resumido na primeira coluna do Quadro 3.

\begin{tabular}{|c|c|c|c|}
\hline \multicolumn{4}{|l|}{ Título do Projeto: Projeto Calha } \\
\hline Resumo Narrativo & \begin{tabular}{|l} 
Indicadores \\
Objetivos
\end{tabular} & $\begin{array}{l}\text { Meios de } \\
\text { Verificação }\end{array}$ & $\begin{array}{l}\text { Pressupostos } \\
\text { Importantes }\end{array}$ \\
\hline \multicolumn{4}{|l|}{$\begin{array}{l}\text { Fim } \\
\text { - desenvolver toda a região } \\
\text { lindeira à hidrovia de modo } \\
\text { adequado (p.7) }\end{array}$} \\
\hline \multicolumn{4}{|l|}{$\begin{array}{l}\text { Propósitos } \\
\text { - modelo de gestão regional } \\
\text { elaborado que operacionalize } \\
\text { as diretrizes do plano } \\
\text { (apresentação) }\end{array}$} \\
\hline $\begin{array}{l}\text { Produtos } \\
\text { - diretrizes específicas } \\
\text { estabelecidas para cada sub- } \\
\text { região lindeira (p.15) }\end{array}$ & $\begin{array}{l}\text { - um documento com } \\
\text { as diretrizes para } \\
\text { cada uma das sub- } \\
\text { regiões do Projeto }\end{array}$ & - o documento & \\
\hline $\begin{array}{l}\text { Insumos } \\
\text { - utilizar as informações que } \\
\text { caracterizam as sub-regiões } \\
\text { do projeto quanto às } \\
\text { necessidades de interferência } \\
\text { para o direcionamento do } \\
\text { desenvolvimento }\end{array}$ & $\begin{array}{l}\text { - um relatório com as } \\
\text { informações sobre as } \\
\text { sub-regiões }\end{array}$ & - o relatório & \\
\hline
\end{tabular}

Quadro 3 - Resumo dos Principais Elementos do Projeto Calha.

O método da Estrutura Lógica estabelece que os pressupostos do projeto devem ser explicitados, o que não ocorreu no Projeto Calha, em nenhum nível hierárquico, conforme nota-se no Quadro 3. Isso implica que a elaboração do projeto não obedeceu ao requisito do método científico, ou seja, não introduziu a incerteza. No nível hierárquico mais baixo, um pressuposto importante seria, por exemplo, que as informações coletadas estivessem adequadas e fossem suficientes para estipular as diretrizes. No nível hierárquico imediatamente superior, implicitamente, o texto pressupõe a continuidade dos estudos. Sabe-se que não houve essa continuidade. Além disso, no mesmo nível pressupôs-se que houvesse interesse em um novo modelo de gestão. Esse aspecto pode ter sido relativamente importante para a interrupção dos estudos. Afinal, o risco de uma redefinição das regiões administrativas do Estado de São 
Paulo pode não ter sido interessante (do ponto de vista político) e colaborado para “minar" a continuidade dos estudos pelos órgãos envolvidos, além de desestimular a implantação das diretrizes estabelecidas no Plano.

Para que o modelo de gestão que seria proposto pelo projeto atingisse a finalidade desejada (o desenvolvimento de toda a região), há fortes pressupostos implícitos. Além da necessidade de investimentos em capital físico, talvez o pressuposto mais importante seja a necessidade de investimentos em outras formas de capital ou até mesmo a transferência de estoques de capitais (nas formas de capitais financeiro, humano e social) de regiões mais desenvolvidas para as regiões abrangidas pelo Projeto Calha. Deve ser ressaltado ainda que a ausência de um indicador objetivamente verificável para o nível de desenvolvimento a ser alcançado leva a interpretações diferentes e consequientemente impedem que se detecte o êxito ou fracasso do projeto. Esse é justamente um problema que ocorre freqüentemente em projetos e que a Estrutura Lógica pretende evitar.

Conforme já mencionado, depois do Projeto Calha, foi elaborado o Plano de Fomento (CESP, 1996), já no governo Covas. Esse plano seria composto por 14 tomos específicos para cada região considerada. Como os estudos não tiveram continuidade até o momento, tais tomos não foram produzidos, e a análise deste Plano limita-se ao único documento disponível e que possibilitou a elaboração do Quadro 4. Nota-se que, mais uma vez, o preenchimento da matriz foi apenas parcial. 


\begin{tabular}{|c|c|c|c|}
\hline \multicolumn{4}{|l|}{ Título do Projeto: Plano de Fomento } \\
\hline Resumo Narrativo & \begin{tabular}{|l} 
Indicadores \\
Objetivos
\end{tabular} & $\begin{array}{l}\text { Meios de } \\
\text { Verificação } \\
\end{array}$ & \begin{tabular}{|l|} 
Pressupostos \\
Importantes
\end{tabular} \\
\hline \multicolumn{4}{|c|}{\begin{tabular}{l|l} 
Fim & \\
- empregos e aumento da arrecadação & \\
de ICMS gerados no interior do estado & \\
- interior paulista inserido na rota do & \\
Mercosul & \\
- qualidade de vida melhorada através & \\
da elevação do padrão sócio-econômico & \\
e do meio ambiente & \\
\end{tabular}} \\
\hline $\begin{array}{l}\text { Propósitos } \\
\text { - desenvolvimento sócio-econômico } \\
\text { fomentado em mais de } 8000 \mathrm{~km} \text { de áreas } \\
\text { lindeiras dos rios Tietê-Paraná } \\
\text { - investimentos privados interiorizados }\end{array}$ & & & $\begin{array}{l}\text { - eclusas de Jupiá e } \\
\text { Três Irmãos entrarão } \\
\text { em operação } \\
\text { - o desnível de Itaipu } \\
\text { será vencido }^{1} \\
\text { - o Plano de } \\
\text { Desenvolvimento do } \\
\text { Vale do Piracicaba } \\
\text { será executado }^{2}\end{array}$ \\
\hline $\begin{array}{l}\text { Produtos } \\
\text { - associações formadas para agirem em } \\
\text { conjunto e de maneira unificada } \\
\text { - criação de pólos hidroindustriais, } \\
\text { turísticos e de recebimento de insumos } \\
\text { agrícolas ao longo da hidrovia } \\
\text { estimulada } \\
\text { - plano de fixação industrial elaborado } \\
\text { - terminais hidroviários para exportação } \\
\text { e importação para o Mercosul } \\
\text { construídos } \\
\text { - novos negócios, principalmente no } \\
\text { ramo de agribusiness criados }\end{array}$ & & & \\
\hline $\begin{array}{ll}\text { Insumos } & \\
-\quad \text { promover reuniões, envolvendo } \\
\text { municípios lindeiros, municípios } \\
\text { polarizadores, empresários e CESP }\end{array}$ & & & \\
\hline
\end{tabular}

Quadro 4 - Resumo dos Principais Elementos do Plano de Fomento.

${ }^{1}$ Ou será feito o transbordo por terra.

${ }^{2}$ Ou será utilizada rodovia até Piracicaba.

Verifica-se no Quadro 4 que o preenchimento da matriz da estrutura lógica para o Plano de Fomento está bastante comprometido, praticamente limitando-se ao resumo do Plano. O Plano de Fomento propôs a realização de reuniões envolvendo 
municípios lindeiros, municípios polarizadores, empresários e a CESP, visando formar associações, estimular a criação de pólos, construir terminais hidroviários e criar novos negócios. Esta relação de causa e efeito entre insumo e produtos, bem como a relação entre estes e os níveis hierárquicos mais elevados do Projeto estão resumidas no Quadro 4. A partir desses produtos gerados, o plano atingiria seu propósito, ou seja, o desenvolvimento de áreas lindeiras dos rios Tietê-Paraná estaria fomentado e os investimentos privados atraídos para o interior do estado. Nota-se que, até este ponto, nenhum pressuposto foi explicitado, o que significa assumir que, uma vez promovidas as reuniões entre municípios, empresários e CESP, com certeza, haverá êxito em atingir os propósitos do Plano. Evidentemente, não pode ter sido isso o que tinham em mente os técnicos que elaboraram o Plano, mas é o que se extrai dele, pois os fortes pressupostos implícitos associados aos diferentes níveis hierárquicos não foram explicitados.

Com relação aos pressupostos implícitos no primeiro nível hierárquico, destaca-se a disponibilidade de recursos, principalmente para a criação dos pólos hidroindustriais, turísticos e de recebimento de insumos agrícolas, a construção de terminais e a criação de empregos. Com relação à formação de associações para agirem em conjunto, um pressuposto importante é a disposição das lideranças locais em participar de reuniões que visassem à formação de associações. Deve ser lembrado que a relutância por parte das autoridades locais tende a ser maior ainda quando essas associações devem ser feitas com outros municípios. Nesse caso, as razões incluem as diferenças partidárias.

Vários pressupostos estão implícitos no segundo nível hierárquico. Por exemplo, para que os investimentos privados se direcionassem para o interior do estado, foi preciso que taxas de juros fossem compatíveis com os retornos a serem oferecidos pelos empreendimentos futuramente instalados no interior. Apesar das inúmeras críticas que as políticas governamentais de juros altos sofrem principalmente pelos empresários, sabe-se que as taxas vigentes no País inviabilizam a realização de vários projetos de investimentos. Além disso, para que o desenvolvimento seja fomentado, políticas voltadas à educação e saúde da população provavelmente se fariam necessárias. Em 
outras palavras, ao buscar a formação de associações, o Plano atua diretamente sobre a formação do estoque de capital social, cuja importância para o desenvolvimento será discutida no próximo capítulo. Entretanto, embora importante, esse estoque de capital, isoladamente, não permitirá que se atinja o desenvolvimento regional.

Os poucos pressupostos explícitos no Plano de Fomento estão associados ao cumprimento do seu objetivo final, e dois deles dizem respeito à viabilidade do transporte hidroviário. Um pressuposto é de que o desnível de Itaipu será vencido ou, mesmo que isso não ocorra, o transporte hidroviário continuaria viável, apesar de ser realizado o transbordo por terra em Itaipu. O plano não é tão incisivo com relação à viabilidade do transporte hidroviário, caso não seja executada a barragem de Santa Maria da Serra, que possibilitaria que a hidrovia chegasse a Piracicaba, mas deixa claro que a execução do Plano de Desenvolvimento do Vale do Piracicaba, do qual a barragem faz parte, é que possibilitará o intercâmbio com o Mercosul. Quanto à aprovação para sua construção, sabe-se que, embora conste no orçamento do estado, a barragem de Santa Maria da Serra tem enfrentado entraves atribuídos a questões ambientais. Um terceiro pressuposto diz respeito à operação de Jupiá e Três Irmãos, cujas obras foram concluídas e, portanto, não seriam empecilhos ao cumprimento da finalidade do Plano.

No Plano de Fomento, não são mencionados indicadores objetivos nem os meios de verificação para estes indicadores. Não seria difícil estabelecer-se alguns indicadores objetivos para esse Plano. Por exemplo, quanto às atividades a serem desenvolvidas (promover reuniões), um número de reuniões periódicas em locais determinados poderia ter sido especificado, de modo que a distância percorrida pelas pessoas envolvidas no projeto, as despesas com viagens e reuniões fossem indicadores objetivamente verificáveis. Os comprovantes relativos a essas despesas bem como as atas das reuniões consistiriam nos meios de verificação para esses indicadores sugeridos. No nível hierárquico imediatamente superior (Produtos), os indicadores seriam o número de associações implantadas, o número de pólos hidroindustriais, turísticos e de recebimentos de insumos agrícolas criados, o plano de fixação industrial elaborado, o número de terminais hidroviários para comercialização com o Mercosul e os novos 
negócios gerados. Os meios objetivamente verificáveis desses indicadores seriam as atas de aberturas e de reuniões das associações e pólos gerados, o documento elaborado (o plano) e os alvarás concedidos para instalação e funcionamento de indústrias e empresas na região abrangida pelo plano.

Nos níveis mais elevados do Plano, os indicadores objetivamente verificáveis também não foram explicitados. Poderiam ser utilizados indicadores divulgados por instituições de pesquisa relacionados ao desenvolvimento humano, condição de vida ou ainda construção civil, ou até mesmo elaborado um indicador específico para a região. Para o nível mais elevado do plano (Fim), a variação percentual no ICMS, no número de empregos e dados sobre transporte no interior de São Paulo para o Mercosul, consistiria nos indicadores objetivamente verificáveis. Também seria necessário optar-se por algum índice de qualidade de vida para completar os indicadores para esse último nível. À exceção desse último indicador, que, uma vez determinado, poderia ser calculado periodicamente ou utilizar-se de algum indicador já disponível nas instituições de pesquisa, os outros poderiam ser verificados através de informações obtidas nas contas do estado.

Além da falta de dados necessários ao preenchimento da matriz de Estrutura Lógica, outra questão que chama a atenção no Plano e já foi mencionada, é a diferença na região considerada no Projeto Calha. Do ponto de vista estritamente técnico, a diferença na utilização das regiões gera dificuldades em aproveitamento dos dados, que, uma vez obtidos para o Calha, poderiam ser úteis na elaboração e execução do Projeto de Fomento. Essa falta de continuidade detectada não foi uma particularidade desses dois projetos mencionados, mas, sim, uma regra observada na atuação governamental no que diz respeito aos planos de desenvolvimento associados ao Vale do Tietê-Paraná, ou seja, desde o Plano de Desenvolvimento Turístico da Hidrovia Tietê-Paraná.

Em suma, os planos de desenvolvimento encontrados para a região do Vale do Tietê como um todo não preenchem as exigências mínimas que deveriam constar nos projetos bem elaborados. Neste estudo, considera-se bem elaborado um projeto que 
apresente elementos suficientes para o preenchimento da matriz usada no Método da Estrutura Lógica. O Master Plan (ADTP, 1996), única iniciativa do setor privado, não permitiu sequer o encadeamento lógico de causa e efeito das ações e resultados do projeto. Os Planos Calha e Fomento deixam lacunas ao não explicarem os pressupostos e impedem que se detectem as responsabilidades pelas falhas. Além disso, a ausência de indicadores objetivamente verificáveis impede que se verifique se os objetivos dos diferentes níveis foram alcançados. É importante lembrar que, se esses indicadores e pressupostos tivessem sido devidamente especificados, mesmo quando não se alcançassem os objetivos aos quais os planos se propunham, seria possível detectarem-se as responsabilidades sobre a frustração das expectativas, o que, não foi possível.

\subsection{Estudos de desenvolvimento econômico para os municípios lindeiros}

Os estudos voltados a municípios específicos do Vale do Tietê-Paraná são de diferentes períodos da história recente. Na fase de construção das obras, os projetos tratavam de municípios localizados mais próximos a elas. São dessa época estudos sobre Ilha Solteira, Avanhandava, Teodoro Sampaio e Rosana. Com a hidrovia, municípios mais próximos dos centros consumidores (Pederneiras e Piracicaba) parecem ter despertado maior interesse, embora o número de projetos a ser analisado ainda seja pequeno. Os projetos encontrados para os municípios foram para Ibitinga, Rosana, Penápolis, Rubinéia, Santa Fé do Sul, Três Fronteiras, Buritama, Lourdes, Turiuba e Zacarias. O Plano para o município de Penápolis mencionou, bastante resumidamente, possibilidades de irrigação (CESP, 1997b).A seguir, serão apresentados os resultados da análise de dois desses projetos que abrangem três municípios cada um deles. Mais uma vez, utilizou-se o Método da Estrutura Lógica. Posteriormente, outros estudos realizados para municípios do Vale do Tietê serão discutidos.

\subsubsection{Análise dos projetos de desenvolvimento para os municípios lindeiros pelo Método da Estrutura Lógica}

A CESP elaborou planos para alguns dos 17 pólos potenciais para novas opções de investimento que estabeleceu ao longo da hidrovia. Dentre esses planos 
encontra-se um para os municípios de Rubinéia, Santa Fé do Sul e Três Fronteiras, que formam um único pólo. A matriz de Estrutura Lógica desse plano encontra-se representada no Quadro 5. Os municípios de Buritama, Lourdes, Turiuba e Zacarias não foram incluídos entre os 17 pólos mencionados, mas fazem parte do "Núcleo de Turismo do Sol”, localizados nos reservatórios de Nova Avanhandava - Buritama, Turiuba e Zacarias - e de Três Irmãos - Buritama e Lourdes. O Quadro 6 apresenta os elementos da matriz da estrutura lógica do Plano de Fomento Turístico para esses três municípios do Núcleo de Turismo do Sol.

O Plano resumido no Quadro 5 insiste na necessidade de engajamento efetivo dos municípios do pólo turístico formado por Rubinéia, Santa Fé do Sul e Três Fronteiras, no Programa Nacional de Municipalização do Turismo (PNMT) (CESP, 1995a). Entretanto, o texto não esclarece o que seria necessário para que tal engajamento ocorresse e, ao apresentar o prognóstico para Rubinéia, deixa a impressão de que os planos Diretor e Turístico, o cadastramento dos municípios no RIMTUR (Roteiro de Informações Básicas para Identificação de Municípios Prioritários para o Desenvolvimento do Turismo pela Embratur) e até mesmo o Conselho e o Fundo Municipal de Turismo seriam necessários para tal engajamento, conforme se observa no trecho que se refere ao PNMT:

"Considerando que o processo de transformação em estância turística é muito moroso e há necessidade de um forte apoio político (pois é necessário passar pela Assembléia Legislativa), a curto prazo (para obtenção de linhas de financiamento - principalmente para investidores), é imprescindível a participação efetiva nesse programa. Assim, faz-se necessário a elaboração de um Plano Diretor e de um Plano de Desenvolvimento Turístico. Já consta do RIMTUR, e possui o Conselho e o Fundo Municipal de Turismo" (CESP, 1995a, p. 29).

\footnotetext{
${ }^{8}$ Os núcleos de turismo foram definidos pela Secretaria de Esportes e Turismo do Estado de São Paulo, em 1993 (CESP, 1995a).
} 
Diante do texto do Plano de Fomento Turístico para Rubinéia, Santa Fé do Sul e Três Fronteiras com relação ao PNMT, entendeu-se que os planos Diretor e Turístico seriam insumos, e o engajamento efetivo na PNMT, um produto, conforme foi indicado no Quadro 5. De qualquer modo, o termo "efetivo" dá margens a diversas interpretações, inclusive de que "algo" deve ser feito para que o engajamento ocorra e que não se trata apenas de uma simples inscrição no programa. Há ainda outra observação necessária referente à exigência de cadastro no RIMTUR e formação de Conselho Municipal de Turismo para obtenção de recursos do FINEP (Financiadora de Estudos e Projetos) para elaborar os planos. Sob esse prisma, os planos poderiam ser vistos como produtos e o cadastramento no RIMTUR e a formação do Conselho, como insumos. Entretanto, uma vez que os três municípios já têm cadastro no RIMTUR e os Conselhos Municipais já estão formados em Rubinéia e Santa Fé do Sul e, na época em que foi elaborado o Plano, já estava em fase de criação em Três Fronteiras, pode-se partir da elaboração dos planos como insumo sem entrar no mérito de como os recursos para elaborá-los serão obtidos. Essa foi a base da seqüência lógica utilizada para elaborar o Quadro 5. Cabe ressaltar que fica reconhecida a fragilidade do Plano de Fomento Turístico, pois até mesmo para a elaboração dos planos Diretor e Turístico há dependência da existência de recursos.

A elaboração dos planos Diretor e Turístico para os municípios de Rubinéia, Três Fronteiras e Santa Fé do Sul contribuiria, juntamente com as sugestões e o prognóstico apresentados no Plano de Fomento Turístico, para que a região fosse auxiliada na formação do pólo turístico e as municipalidades fossem devidamente assessoradas em direção ao desenvolvimento. Este é parte do encadeamento lógico entre o nível hierárquico mais baixo (insumos) e o nível imediatamente superior (produtos), conforme consta no Quadro 5. Quanto aos outros insumos considerados, chama a atenção a construção de marinas e terminal hidroviário para passageiros. Não se trata de atividades tão simples de serem realizadas, pois carecem de projetos, e isso não foi lembrado de modo específico. Na realidade, o texto ressaltou a necessidade de outros estudos e considerou as proposições/ recomendações apresentadas no plano apenas de 
caráter preliminar. Pressupôs-se, portanto, no nível hierárquico mais baixo, que outros estudos seriam realizados, e os produtos (as obras construídas) efetivamente existiriam.

Os recursos para tais obras, entretanto, não foram devidamente tratados no plano que se limitou a mencionar vagamente possibilidades de obtenção de recursos.

\begin{tabular}{|c|c|c|c|}
\hline \multicolumn{4}{|c|}{ Título do Projeto: Plano de Fomento Turístico: Rubinéia, Santa Fé do Sul e Três Fronteiras } \\
\hline Resumo Narrativo & \begin{tabular}{|l|} 
Indicadores \\
Objetivos
\end{tabular} & \begin{tabular}{|l|} 
Meios de \\
Verificação
\end{tabular} & Pressupostos Importantes \\
\hline \multicolumn{4}{|c|}{\begin{tabular}{l|l} 
Fim & \\
- desenvolvimento das comunidades sob influência & \\
da hidrovia Tietê-Paraná (p.86) & \\
- melhoria da qualidade de vida (p.86) & \\
\end{tabular}} \\
\hline $\begin{array}{l}\text { Propósitos } \\
\text { - implantados o turismo fluvial, ecológico social, } \\
\text { rural, desportivo, cultural e educativo nos } \\
\text { municípios do pólo (p.56 a 73) } \\
\text { - a indústria do turismo e lazer desenvolvida nos } \\
\text { municípios lindeiros à hidrovia Tietê-Paraná }\end{array}$ & & & $\begin{array}{l}\text { - o turismo é um agente de } \\
\text { desenvolvimento prioritário ao longo da } \\
\text { hidrovia Tietê Paraná (p.7) } \\
\text { - empreendimentos ao longo da hidrovia } \\
\text { que se utilizam de recursos nativos e } \\
\text { disponibilidades tecnológicas locais } \\
\text { apresentam investimentos e prazos de } \\
\text { retorno menores e elevada geração } \\
\text { regional de empregos (p.7) }\end{array}$ \\
\hline $\begin{array}{l}\text { Produtos } \\
\text { - a região incentivada e auxiliada na formação de } \\
\text { um pólo turístico (p. apresentação) } \\
\text { - municipalidades assessoradas na busca de seu } \\
\text { crescimento econômico e desenvolvimento social } \\
\text { com o mínimo de impacto no meio ambiente e com } \\
\text { a conservação do patrimônio natural (p.3) } \\
\text { - engajamento efetivo na PNMT } \\
\text { - ranchos aproveitados para hospedagens } \\
\text { - terminal de passageiros construído } \\
\text { - passeios e viagens fluviais programadas } \\
\text { - marinas construídas com infra-estrutura de apoio } \\
\text { - trilhas e pistas de cooper implantadas } \\
\text { - pesca implementada } \\
\text { - imagem de produto regional criada } \\
\text { - infra-estrutura turística e de apoio ampliada } \\
\text { - projetos para hotéis e restaurantes elaborados }\end{array}$ & & & $\begin{array}{l}\text { - localização privilegiada na rota do } \\
\text { Mercosul despertará o interesse de } \\
\text { empresários e atrairá turistas (p.apres.) } \\
\text { - o turismo da hidrovia terá como apelo as } \\
\text { possibilidades ecológicas-fluviais estas } \\
\text { modalidades de turismo estarão integradas } \\
\text { entre Brasil, Argentina, Uruguai e } \\
\text { Paraguai (p.7) } \\
\text { - empresários interessados em investir ao } \\
\text { longo da hidrovia Tietê-Paraná terão } \\
\text { inúmeros incentivos: energia (elétrica, } \\
\text { álcool e gasoduto Brasil-Bolívia), vias de } \\
\text { acesso, mão-de-obra e matéria-prima e } \\
\text { linhas de crédito (MICT/SNTS) (p.11); } \\
\text { - a hidrovia se constituirá numa artéria de } \\
\text { desenvolvimento do transporte comercial } \\
\text { e em especial do turismo e do lazer } \\
\text { através do aproveitamento das águas dos } \\
\text { reservatórios (p.4) } \\
\text { - elevado número de municípios } \\
\text { marginais à hidrovia, apresentam vocação } \\
\text { nitidamente turística em função das } \\
\text { condições naturais e das potencialidades } \\
\text { originadas com os reservatórios (p.7) } \\
\text { - a ponte rodoferroviária será atração e } \\
\text { proporcionará maior intercâmbio e } \\
\text { movimentação turística entre os estados } \\
\text { (p.13) } \\
\text { - a hidrovia estará em dez anos } \\
\text { absorvendo mais de US\$120 milhões de } \\
\text { investimentos privados para o setor } \\
\text { turístico(p.7) } \\
\text { - haverá recursos disponíveis para os } \\
\text { municípios engajados na PNMT (p.85) }\end{array}$ \\
\hline
\end{tabular}

Quadro 5 - Resumo dos principais elementos do Plano de Fomento Turístico: Rubinéia, Santa Fé do Sul e Três Fronteiras. 


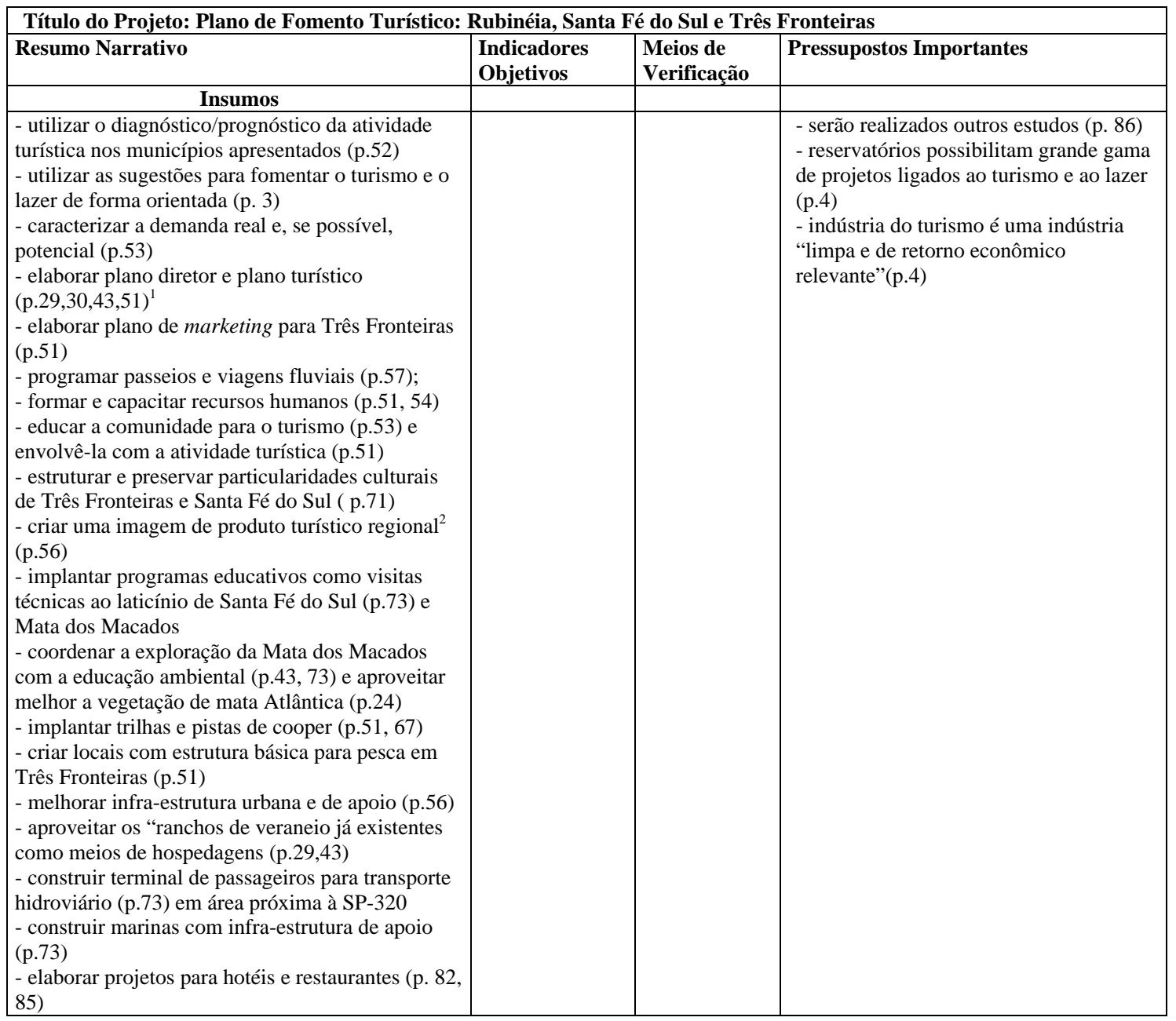

Quadro 5 - Resumo dos principais elementos do Plano de Fomento Turístico: Rubinéia, Santa Fé do Sul e Três Fronteiras.

${ }^{1}$ Santa Fé possui o Plano Municipal de Turismo - Plantur.

${ }^{2}$ Imagem a ser criada a médio e longo prazo e talvez articulada com o COTUNOR Conselho Regional de Desenvolvimento do Turismo do Noroeste Paulista.

Uma vez obtidos os produtos do Plano de Fomento Turístico para os municípios de Rubinéia, Santa Fé do Sul e Três Fronteiras, é preciso verificar se os propósitos seriam atingidos. Nesse ponto, nota-se que os pressupostos existentes são muito fortes e comprometem o alcance dos propósitos. São pressupostos associados à hidrovia e alguns deles à rota do Mercosul. Dadas as constantes dificuldades econômicas pelas quais passam os países do Mercosul e o conseqüente enfraquecimento do acordo, esses pressupostos podem não se cumprir, e o desenvolvimento do turismo ao longo da 
hidrovia ser comprometido, ainda que apenas no curto prazo. Especificamente quanto ao pressuposto relacionado a incentivos que os empresários teriam, além das dificuldades associadas à rota Mercosul, há ainda o risco em relação à própria hidrovia. Embora as possibilidades de fechamento do canal construído em Pereira Barreto para ligar os rios Tietê e Paraná pareça remota, foi considerada, durante o período que antecedeu ao recente racionamento de energia, para elevar os níveis de água dos reservatórios. Evidentemente, o próprio risco já é um desestímulo a mais para os empresários, em geral desmotivados, principalmente pelas taxas de juros vigentes no País. Com o comprometimento do alcance dos Propósitos do Plano, está conseqüentemente comprometido o cumprimento do objetivo final. Esse comprometimento é maior ainda ao se constatar que os pressupostos existentes para o alcance do fim do Plano de Fomento Turístico (o desenvolvimento das comunidades lindeiras à hidrovia e melhoria da qualidade de vida) também estão relacionados ao retorno de investimentos realizados ou a serem realizados em empreendimentos ao longo da hidrovia.

O que mais chama a atenção no Quadro 5, mais uma vez é a ausência total de indicadores objetivos e seus respectivos meios de verificação. Assim, como nos planos discutidos anteriormente, são válidas as observações quanto à impossibilidade de se avaliar objetivamente o êxito ou fracasso das etapas do plano. A título de ilustração, alguns indicadores objetivos para os insumos que consistam em obras a serem construídas ou melhorias na infra-estrutura poderiam ser relativamente simples de serem elaborados, considerando-se indicadores da construção civil e estabelecendo-se um prazo para atingi-los. Esse tipo de indicador poderia ser verificável através de informações a serem obtidas nas prefeituras municipais, como, por exemplo, alvarás para construção, despesas com obras de saneamento, instalações elétricas e outras. Indicadores do mesmo tipo poderiam ser utilizados para os produtos associados a esses insumos. $\mathrm{O}$ engajamento efetivo no PNMT dentro de um prazo definido poderia completar os indicadores objetivamente verificáveis para os produtos, e a documentação referente (atas, lista de presenças constando participação de representantes municipais, 
etc) seriam os meios de verificação do engajamento efetivo no PNMT dentro de determinado prazo.

A mesma ausência de indicadores objetivos e seus meios de verificação detectada no Plano para Rubinéia, Santa Fé do Sul e Três Fronteiras é observada no Plano de Fomento Turístico para os municípios de Buritama, Lourdes, Turiuba e Zacarias (CESP, 1998), cujo resumo encontra-se no Quadro 6. Assim, além de analisar o encadeamento lógico encontrado e apresentado no resumo narrativo e dos pressupostos importantes, deve ser salientado que as sugestões apresentadas para o plano anterior também são válidas para esse plano. Apesar da semelhança entre os dois planos, detectaram-se algumas diferenças sutis que serão destacadas.

O Plano de Fomento resumido no Quadro 6 apresenta como insumos idéias sobre alternativas de turismo que, uma vez bem compreendidas, gerarão planos diretores, de turismo e de marketing, além de auxiliarem a municipalidade a encontrar formas de desenvolvimento. São idéias gerais, informando sobre possibilidades de aproveitamento dos rios e lagos, e a grande maioria encontra-se em todos os planos analisados. Tais idéias deverão colaborar para a elaboração de outros planos. É interessante notar que essa é uma diferença no caminho lógico seguido nesse plano em relação ao anterior, no qual os planos diretores e de turismo foram entendidos como insumos. O resultado dessa interpretação foi uma sequiência lógica na qual um insumo bastante importante do Plano de Fomento Turístico para os municípios de Buritama, Lourdes, Turiuba e Zacarias é o engajamento dos municípios no PNMT que, juntamente com as idéias apresentadas e com a estruturação técnica dos municípios (que se beneficiariam também do engajamento na PNMT) gerariam os planos diretores, turístico e marketing, bem como recursos humanos capacitados. Deve ser lembrado que o plano reconhece a necessidade de mais informações sobre as idéias apresentadas. 


\begin{tabular}{|c|c|c|c|}
\hline \multicolumn{4}{|c|}{ Título do Projeto: Plano de Fomento Turístico: Buritama, Lourdes, Turiuba e Zacarias } \\
\hline Resumo Narrativo & $\begin{array}{l}\text { Indicadores } \\
\text { Objetivos } \\
\end{array}$ & \begin{tabular}{|l|} 
Meios de \\
Verificação
\end{tabular} & Pressupostos Importantes \\
\hline \multicolumn{4}{|l|}{$\begin{array}{l}\text { Fim } \\
\text { - melhoria da qualidade de vida da população } \\
\text { (p.42) } \\
\text { - desenvolvimento das comunidades lindeiras } \\
\text { incentivado e promovido (p.42) }\end{array}$} \\
\hline $\begin{array}{l}\text { Propósitos } \\
\text { - atrações municipais melhoradas e } \\
\text { ampliadas(p.42); } \\
\text { - receitas municipais maximizadas (p42) }\end{array}$ & & & $\begin{array}{l}\text { - turismo é um agente de } \\
\text { desenvolvimento prioritário ao longo } \\
\text { da hidrovia (p.3); } \\
\text { - a hidrovia estará em dez anos } \\
\text { absorvendo mais de US } \$ 120 \text { milhões } \\
\text { de investimentos privados para o } \\
\text { setor turístico (p.3) }\end{array}$ \\
\hline $\begin{array}{l}\text { Produtos } \\
\text { - municipalidades assessoradas na busca do } \\
\text { crescimento econômico e desenvolvimento social } \\
\text { (p.3) } \\
\text { - plano de marketing desenvolvido (p.38) } \\
\text { - turismo fluvial, ambiental (ecológico ou } \\
\text { ecoturismo), social, rural, desportivo, } \\
\text { gastronômico e cultural desenvolvidos } \\
\text { - competições náuticas implementadas } \\
\text { - viagem fluvial pelo Ribeirão Santa Bárbara até o } \\
\text { Rio Tietê no Reservatório de Avanhandava } \\
\text { implementada e incluindo Buritama em roteiros } \\
\text { programados para os municípios lindeiros à } \\
\text { hidrovia (p.25) } \\
\text { - construção de marinas com toda a infra-estrutura } \\
\text { (p.32) } \\
\text { - planos diretor e turístico para os municípios } \\
\text { elaborados e comunidade educada para o turismo } \\
\text { (p.36-37-41) } \\
\text { - recursos humanos (mão de obra voltada ao } \\
\text { turismo e hotelaria) formados e capacitados (p.37) } \\
\text { - ações de marketing subsidiadas pelas pesquisas }\end{array}$ & & & $\begin{array}{l}\text { - empreendimentos ao longo da } \\
\text { hidrovia se que se utilizam de } \\
\text { recursos nativos e disponibilidades } \\
\text { tecnológicas locais apresentam } \\
\text { investimentos e prazos de retorno } \\
\text { menores e elevada geração regional } \\
\text { de empregos (p.3) } \\
\text { - regiões a oeste e noroeste do } \\
\text { Estado de São Paulo terão condições } \\
\text { de atrair turistas locais, regionais, } \\
\text { estaduais, interestaduais e até } \\
\text { mesmo internacionais, via Mercosul } \\
\text { (p.6) } \\
\text { - a tendência de crescimento no } \\
\text { turismo na hidrovia é real }\end{array}$ \\
\hline $\begin{array}{l}\text { - municipalidades assessoradas na busca do } \\
\text { crescimento econômico e desenvolvimento social } \\
\text { (p.3) } \\
\text { - plano de marketing desenvolvido (p.38) } \\
\text { turismo fluvial, ambiental (ecológico ou } \\
\text { ecoturismo), social, rural, desportivo, } \\
\text { gastronômico e cultural desenvolvidos } \\
\text { - competições náuticas implementadas } \\
\text { - viagem fluvial pelo Ribeirão Santa Bárbara até o } \\
\text { Rio Tietê no Reservatório de Avanhandava } \\
\text { implementada e incluindo Buritama em roteiros } \\
\text { programados para os municípios lindeiros à } \\
\text { hidrovia (p.25) } \\
\text { - construção de marinas com toda a infra-estrutura } \\
\text { (p.32) } \\
\text { - planos diretor e turístico para os municípios } \\
\text { elaborados e comunidade educada para o turismo } \\
\text { (p.36-37-41) } \\
\text { - recursos humanos (mão de obra voltada ao } \\
\text { turismo e hotelaria) formados e capacitados (p.37) } \\
\text { - ações de marketing subsidiadas pelas pesquisas }\end{array}$ & & & $\begin{array}{l}\text { - empreendimentos ao longo da } \\
\text { hidrovia se que se utilizam de } \\
\text { recursos nativos e disponibilidades } \\
\text { tecnológicas locais apresentam } \\
\text { investimentos e prazos de retorno } \\
\text { menores e elevada geração regional } \\
\text { de empregos (p.3) } \\
\text { - regiões a oeste e noroeste do } \\
\text { Estado de São Paulo terão condições } \\
\text { de atrair turistas locais, regionais, } \\
\text { estaduais, interestaduais e até } \\
\text { mesmo internacionais, via Mercosul } \\
\text { (p.6) } \\
\text { - a tendência de crescimento no } \\
\text { turismo na hidrovia é real }\end{array}$ \\
\hline
\end{tabular}

Quadro 6 - Resumo dos principais elementos do Plano de Fomento Turístico: Buritama, Lourdes, Turiuba e Zacarias. 


\begin{tabular}{|c|c|c|c|}
\hline Título do Projeto: Plano de Fomento Turístico: B & Iritama, Lo & s, Turiub & carias \\
\hline Resumo Narrativo & \begin{tabular}{|l} 
Indicadores \\
Objetivos
\end{tabular} & \begin{tabular}{|l|} 
Meios de \\
Verificacão
\end{tabular} & Pressupostos Importantes \\
\hline 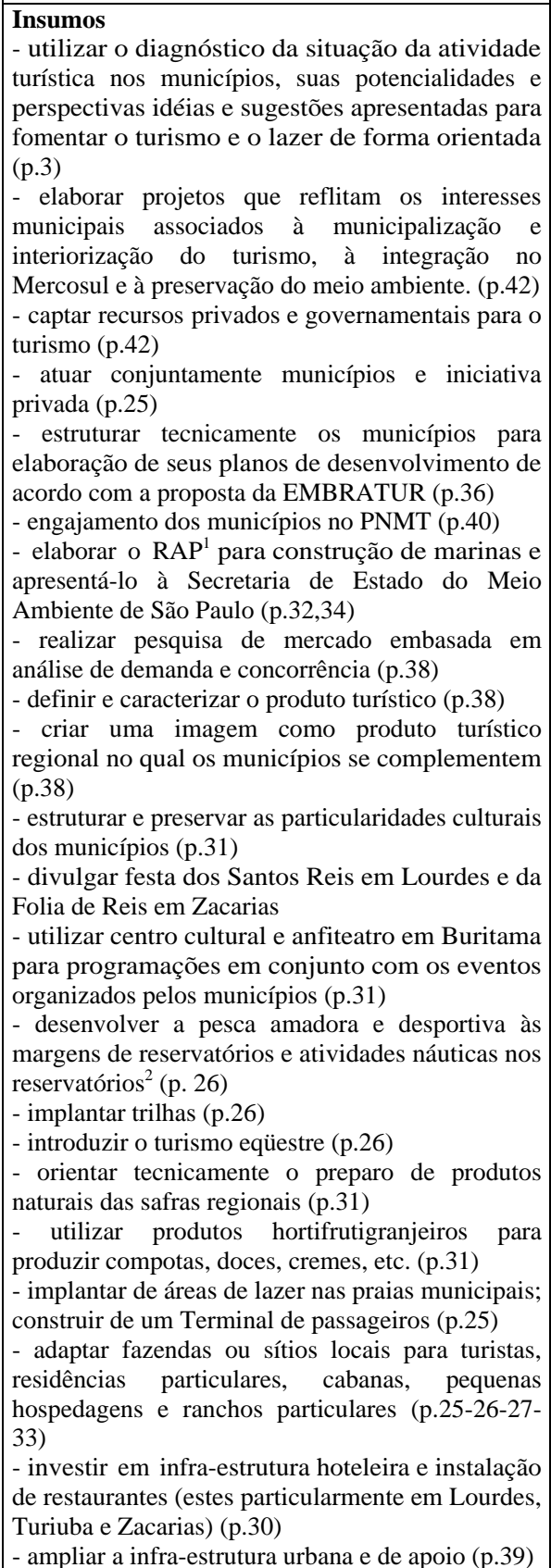 & & & $\begin{array}{l}\text { - os empresários interessados em } \\
\text { investir ao longo da hidrovia terão } \\
\text { inúmeros incentivos, dentre eles } \\
\text { disponibilidade de energia (elétrica, } \\
\text { álcool e gasoduto Brasil-Bolívia), } \\
\text { vias de acesso, matérias primas e } \\
\text { financiamento(p.3) } \\
\text { - as regiões a oeste e noroeste do } \\
\text { Estado de São Paulo apresentam um } \\
\text { cenário favorável para investimentos } \\
\text { - pesquisas de mercado e análises } \\
\text { subsidiarão de maneira consistente e } \\
\text { detalhada o projeto e execução dos } \\
\text { empreendimentos turísticos (p.42) } \\
\text { - agentes municipais do PNMT } \\
\text { embasarão as municipalidades a dar } \\
\text { prosseguimento a todas estas ações } \\
\text { em descrição } \\
\text { - serão captados recursos financeiros } \\
\text { - haverá linhas de financiamento } \\
\text { disponíveis para municípios } \\
\text { engajados na PNMT inclusive para } \\
\text { elaborar planos diretores, planos e } \\
\text { projetos turísticos (p.40) } \\
\text { - RAP aprovado pela Secretaria de } \\
\text { Estado do Meio Ambiente de São } \\
\text { Paulo }\end{array}$ \\
\hline
\end{tabular}

\section{Quadro 6 - Resumo dos principais elementos do Plano de Fomento Turístico: Buritama,} Lourdes, Turiuba e Zacarias.

${ }^{1}$ Relatório Ambiental Preliminar.

${ }^{2}$ Em Lourdes não há possibilidade de desenvolver atividades náuticas. 
Além das idéias de caráter geral apresentadas no plano de Fomento Turístico para Buritama, Lourdes, Turiuba e Zacarias, há alguns poucos aspectos que foram especificados para esses municípios e, portanto, foram incluídos entre os insumos. É o caso da divulgação das festas, implantação de trilhas, introdução ao turismo eqüestre e da necessidade de se desenvolver a pesca e as atividades náuticas nos reservatórios. Uma vez que os municípios em questão não têm nenhuma tradição turística, essas medidas iniciais, embora bastante simples, seriam importantes para neles se começar a implantação do turismo. Entretanto, a implantação efetivamente só ocorrerá se houver uma infra-estrutura adequada, e esse aspecto é lembrado no texto, ao sugerir a adaptação de fazendas e investimentos em infra-estrutura hoteleira e de restaurantes e infraestrutura de apoio, conforme indicado pelos insumos que tratam especificamente dessas questões.

No Plano de Fomento para Buritama, Lourdes, Turiuba e Zacarias, foi lembrado que, para construção de marinas, há necessidade de elaboração e aprovação do Relatório Ambiental Preliminar (RAP). Isso faz com que o RAP aprovado seja um insumo e, pressupondo-se que seja aprovado pela Secretaria e que haja recursos, o produto serão marinas construídas. Essa é uma diferença em relação ao plano anterior resumido no Quadro 5, pois a necessidade do RAP não foi mencionada. Ao explicitar a exigência do RAP, o plano mostra também sua fragilidade quanto a se obter o produto implantação do turismo fluvial. Nesse plano, a existência de uma marina completa é apontada como "importante" para a "implantação do turismo fluvial" (CESP, 1998, p.32) e necessária - assim como os terminais e atracadouros - "para uma parada segura do 'houseboat'..." (CESP, 1998, p.34). Dessa forma, entende-se que marinas construídas e turismo fluvial implantado podem estar ambos como produtos, desde que por turismo fluvial, entenda-se utilização de embarcações menores, o que, evidentemente, é bastante limitante. No plano discutido anteriormente, a construção de marina com infra-estrutura completa é considerada "principal condição para implantação do turismo fluvial" (CESP, 1995a, P.73). Essa diferença no texto contribuiu na decisão de considerar a 
construção de marinas como insumo no plano para Rubinéia, Santa Fé do Sul e Três Fronteiras e como produto no outro.

A idéia de planejar um grupo de municípios visando à formação de um pólo é uma evolução em relação a outros planos nos quais se enfocou apenas um município, como nos planos para o município de Rosana (CESP, 1993) e Ibitinga (CESP, 1995b). Para esse último, dada a particularidade de possuir uma indústria de bordado reconhecida nacionalmente, um plano individual é justificável. O município de Rosana, isoladamente, corresponde a um dos pólos potenciais de investimento ao longo da hidrovia e mereceu, assim como Ibitinga, um plano específico para o município. Por terem sido elaborados exatamente nos mesmos moldes que os dois últimos planos analisados, a matrizes para os planos de Rosana e Ibitinga não serão incluídas neste trabalho a fim de não se estender desnecessariamente a discussão sobre projetos e prosseguir a análise sobre o desenvolvimento dos municípios lindeiros. Ressalta-se, porém que as mesmas críticas e sugestões apresentadas para os dois últimos projetos cujas matrizes foram apresentadas são perfeitamente válidas para os projetos para Rosana e Ibitinga.

\subsubsection{Aspectos importantes sobre o desenvolvimento de municípios lindeiros}

O município cujo desenvolvimento está historicamente mais associado ao aproveitamento das obras sobre o rio Tietê é, provavelmente, Barra Bonita. A construção da usina hidrelétrica, que recebeu o nome do município, iniciou-se em 1957 e, segundo Farrenberg (1998), foi a primeira obra de aproveitamento múltiplo do Rio Tietê. ${ }^{9}$ As condições sócio-econômicas do Vale do Tietê não se alteraram significativamente com a implantação dos projetos hidroenergéticos, e Farrenberg atribuiu esse fato à política de implantação de rodovias. No período entre 1950 e 1970, a implantação de rodovias caracterizou-se "como a maior expansão do sistema rodoviário ocorrido nos países capitalistas" (Farrenberg, 1998, p.6). Deve ser ressaltado que isso ocorria justamente

\footnotetext{
${ }^{9}$ Por aproveitamento múltiplo, ainda de acordo com Farrenberg (1998, p.6), entende-se que, além das usinas hidrelétricas, há "as estruturas para a instalação das eclusas, visando a transposição dos desníveis a serem criados com a formação dos reservatórios, mantendo-se, dessa forma, a navegabilidade."
} 
quando se realizava grande parte dos investimentos estatais em capital físico (as obras de hidrelétricas) ao longo dos rios.

Passado o período em que o estado exercia fortemente as funções de planejador, lideranças municipais e comunidades lindeiras interessaram-se pelo aproveitamento da hidrovia. Evidentemente, tal interesse não foi uniforme e reflete-se tanto nos estudos de caráter municipais quanto na organização desses municípios para o aproveitamento das oportunidades de desenvolvimento geradas pelas obras. De acordo com Farrenberg (1998), apenas 16 municípios utilizam-se da hidrovia, uma vez que contam com terminal multimodal de carga. Cabe lembrar que os terminais podem ser isolados (quando atendem apenas a uma empresa) ou agrupados, formando complexos de terminais multimodais. Esses últimos encontram-se em menor número ao longo da hidrovia (quatro), sendo que três foram, segundo a mencionada autora, implantados no trecho paulista da hidrovia (terminais de Anhembi, Pederneiras e Araçatuba). ${ }^{10}$. Quanto à organização dos municípios lindeiros, é importante ressaltar que quatro deles (Piracicaba, Jaú, Lins e Araçatuba) são sede de cooperativas criadas com o intuito de aproveitar as possibilidades de desenvolvimento associadas à hidrovia. Com relação ao interesse despertado em investidores privados, o município de Pederneiras, à margem esquerda do rio Tietê, parece ter se destacado, dentre os lindeiros. As razões para esse interesse são as condições locacionais privilegiadas que apresenta.

Farrenberg (1998) analisou diversos aspectos do município de Pederneiras para depois relacionar alguns deles à instalação de empresas em resposta à implantação do complexo intermodal. Em conseqüência da localização privilegiada, surgiu o interesse por parte de empresas (inclusive multinacionais) em instalar-se nesse município, às margens da hidrovia. Farrenberg escolheu Pederneiras para realizar seu estudo de caso sobre a hidrovia principalmente por considerá-lo com "melhores

\footnotetext{
${ }^{10} \mathrm{O}$ quarto terminal multimodal encontra-se em território goiano, no município de São Simão. De acordo com Farrenberg (1998), treze municípios paulistas apresentam multimodais isolados: Jaú, Conchas, Piracicaba-distrito Anhumas, Andradina, Santa Maria da Serra, Boracéia, Iturama, Brejo Alegre, Bariri, Barra Bonita, Ilha Solteira, Presidente Epitácio e Panorama. Outros dois são Guaíra, no Estado do Paraná, e Hernandarias, no Paraguai.
} 
condições para expansão de empreendimentos usuários da Hidrovia Tietê-Paraná e para avaliação das alterações decorrentes" (Farrenberg, 1998, p.8). A autora ressalta que se encontra nesse município o único entroncamento hidro-ferro-rodoviário existente ao longo do trecho Tietê da hidrovia, no reservatório da Usina Hidroelétrica (UHE) Álvaro Souza Lima - Bariri. Constituem o entroncamento multimodal: a hidrovia Tietê-Paraná, a rodovia SP- $225^{11}$, uma variante da SP-261 ${ }^{12}$, e a malha da Ferroban (antiga Fepasa). Sobre essa última, a autora lembra que a instalação do terceiro trilho no trecho de acesso ao município, em 1998, tornou Pederneiras "um dos cinco pontos do país com disponibilidade de ferrovia com bitola larga e estreita, o que permite o acesso de qualquer composição ferroviária circulante no Brasil” (Farrenberg, 1998, p.47).

A análise realizada por Farrenberg (1998) foi apresentada depois de uma breve revisão sobre a hidrovia e considerações sobre suas perspectivas e obstáculos. Assim, Pederneiras foi primeiramente inserida pela autora em um contexto mais amplo (a hidrovia) para depois detalhar sua situação específica. Sobre a formação do município, foi lembrado seu vínculo à implantação da ferrovia. De certa forma, desde os primórdios de sua existência, o município usufruiu vantagens de sua localização em relação às vias de transporte. Quanto a sua economia, em relação aos municípios que compõem a Região Administrativa de Bauru, Pederneiras apresenta características semelhantes. Por exemplo, seus principais produtos agrícolas são os mesmos da região (atualmente predomina a cana-de-açúcar, mas já foi o café e a pecuária ao longo de diferentes períodos de sua história). Seguindo o caminho traçado por Bauru e Jaú, em Pederneiras há predominância do setor terciário. Já o setor secundário, também como em outros municípios da região, é pouco expressivo. Apesar dessa pouca expressividade das indústrias na região, Farrenberg $(1998$, p.43) ressalta que, conforme dados da Secretaria do Meio Ambiente do estado ${ }^{13}$, nos anos de 1980, a região de Bauru foi a que mais se destacou no centro-oeste do estado em termos de área industrial construída. Mesmo assim, ainda de acordo com Farrenberg, a região estava classificada apenas em sexto

\footnotetext{
${ }_{11}^{11}$ que interliga Bauru, Jaú e Pederneiras à Marechal Rondon - SP-300.

12 na época do trabalho de Farrenberg, essa variante ainda não estava pavimentada.
} 
lugar no conjunto do interior paulista. Apesar das semelhanças com outros municípios da região, Pederneiras teve a particularidade de apresentar um setor oleiro-ceramista que foi impactado com a inundação de várias jazidas de argila que alimentavam as unidades produtoras, para instalar-se, em meados dos anos de 1960, a Usina Hidrelétrica Álvaro Souza Lima - Bariri.

As alterações pelas quais passou o município de Pederneiras e que são relacionadas à hidrovia parecem ter suas origens com a instalação da hidrelétrica Álvaro Souza Lima - Bariri. Uma das alterações foi a inundação das jazidas de argila que se encontravam na área inundada (que correspondia, de acordo com Farrenberg (1998), a $2,8 \%$ da área total do município). Já as consequiências relacionadas à inserção do complexo de terminais multimodais no município foram mais benéficas, ainda que subaproveitadas até o momento e bem aquém das expectativas geradas no município. $\mathrm{O}$ terminal de areia da Tratex, instalado na década de 1970, é o exemplo mais antigo, citado por Farrenberg, da utilização da faixa marginal ao reservatório, "posteriormente à instalação da Tratex, chegaram na área a empresa Meca Navegação S.A. e o Estaleiro Centro-Oeste, da própria Meca, em 1985" (Farrenberg, 1998, p.68). A autora enumera as alterações pelas quais passou o parque industrial de Pederneiras e que consistem na ampliação deste. Primeiramente, verificou-se a instalação de duas empresas associadas à Hidrovia Tietê-Paraná: a Torque e a Mauri do Brasil (do grupo Burns Philp, que atua em 24 países). No mesmo período, instalou-se em Pederneiras a Comercial Quintella S.A. Ainda segundo Farrenberg, mais recentemente foram adquiridos três lotes na área do complexo de terminais pelas empresas Moinhos Santista, Fert Port e Libra Navegação (CNT).

A fim de se compreender melhor os entraves ao desenvolvimento de Pederneiras, é necessário discutir alguns problemas que se sucederam à instalação das empresas e colaboraram para a frustração das expectativas geradas. A Tratex atua na "extração de areia, do leito dos reservatórios de Bariri e Barra Bonita, e transbordo da

13 SECRETARIA DO MEIO AMBIENTE DO ESTADO DE SÃO PAULO.Tendências de industrialização no interior do Estado de São Paulo, 1989. 
matéria prima para caminhões que se utilizam da SP-225, transportando para a Tratex Concreteira, sediada em Jaú” (Farrenberg, 1998, p.68). Dessa forma, em relação ao valor agregado, esse último município é beneficiado. Quanto ao número de empregos, a Tratex mantém apenas sete funcionários, com salários próximos à média do município. A Meca, que, quando em funcionamento chegou, empregava 205 pessoas, vendeu seus ativos para a Sartco Ltda, empresa de navegação do grupo Archer Daniel Midland, multinacional do ramo de indústria alimentícia. De acordo com Farrenberg, a Sartco pretende direcionar os serviços para a continuidade do transporte de grão, e esperava-se uma geração de 40 novos postos de trabalho. O estaleiro da Torque, que chegou a empregar 150 funcionários, foi desativado dado a baixa procura por construções de embarcações fluviais. Com a desativação, 75 pessoas perderam o emprego e a empresa passou a atuar apenas na atividade de transporte como Operador de Transporte Multimodal (OTM), mas havia perspectivas de retomar as atividades do estaleiro. A Mauri do Brasil construiu uma fábrica de fermento cuja capacidade, segundo Farrenberg, é de 35 mil tonelada/ ano e emprega 400 pessoas. O transporte hidroviário foi utilizado apenas experimentalmente e substituído pelo rodoviário. Assim, seja pela desativação de estaleiro, pela desistência do uso da hidrovia, pelo baixo número de empregos gerados ou ainda pela baixa contribuição das empresas à arrecadação ${ }^{14}$ municipal, a recente história da utilização do complexo de Pederneiras sugere a existência de "gargalos" que impediram seu bom aproveitamento.

Das empresas que se instalaram às margens do reservatório, a Comercial Quintella parece ter exercido papel de fundamental importância. Essa empresa, de acordo com Farrenberg (1998), é 100\% nacional e durante dez anos foi uma trading de soja e passou a atuar no ramo de logística de transporte como Operador Multimodal de Transporte. Além de Pederneiras (onde atua no transbordo de grãos e farelo de soja), conta com instalações em São Simão, Colômbia, Santos, Campinas e São Paulo. Sua importância quanto ao número de empregos gerados e arrecadação municipal também não é grande. Segundo Farrenberg, no terminal, trabalham 19 pessoas, nas embarcações,

\footnotetext{
${ }^{14}$ A participação da Tratex representava $1 \%$ do total arrecadado.
} 
38, sendo que, desses últimos, apenas $50 \%$ residem em Pederneiras e outra metade, em Presidente Epitácio. Quanto à arrecadação, como a origem da carga é São Simão, a empresa não recolhe o ICMS. Ainda conforme Farrenberg, apenas o ICMS cobrado da Ferroban por iniciar-se nova modalidade de transporte em Pederneiras beneficia o município. Assim, a contribuição era de apenas $1 \%$ da receita municipal. A importância da Comercial Quintella no complexo de terminal está relacionada à implantação deste, conforme pode ser concluído a partir do trecho:

“A instalação da terceira empresa usuária da Hidrovia fez parte de um planejamento da CESP, visando incentivar a utilização do sistema. Em 1991, foi implantado um terminal, através de parceria do Estado com a iniciativa privada, o qual foi concedido por 30 anos à empresa Comercial Quintella S.A.. Concomitantemente à instalação portuária, a empresa construiu 2 silos para o armazenamento de grãos e farelos, moega, esteira e os demais equipamentos que possibilitam o transbordo da carga. Através do convênio Quintella/CESP e Fepasa, foi instalado o píer no reservatório $\left(40 \mathrm{~m}^{2}\right)$ e construído o ramal ferroviário derivado da estrada de ferro Ferroban" (Farrenberg, 1998, p. 69).

Dentre os entraves que existiram ao desenvolvimento de Pederneiras associados à utilização das obras no Rio Tietê, é possível que alguns remontem à instalação do complexo de terminais e teriam permanecido na forma de administração deste. Algumas considerações podem ser encontradas no trabalho de Farrenberg (1998), já mencionado, mas a autora não questiona o convênio realizado pela CESP e a Comercial Quintella. Esse convênio foi alvo de crítica por parte de lideranças regionais locais. Essas críticas dizem respeito à possibilidade de cobrança de taxas desestimuladoras do transporte hidroviário por parte da Comercial Quintella que, após a 
conclusão da obra, adquiriu o direito de explorar o terminal e cobrar taxas dos usuários. $^{15}$

As razões para a implantação do complexo em Pederneiras anteriormente a Jaú e outras obras na hidrovia concluídas nos anos noventa parecem ter raízes em interesses políticos que remontam ao Governo Fleury (período 1991-1994). É dessa fase o convênio firmado entre o governo do estado, a CESP, a Fepasa e a Comercial Quintella. A essa última, conforme já mencionado, coube a construção do terminal. Não cabe aqui discutir o mérito do convênio entre governo e setor privado em si, mas sim questionar por que outros municípios e talvez até mesmo outras empresas parecem excluídos. Por exemplo, o município de Jaú, à margem direita do rio Tietê, apresenta, de acordo com Farrenberg (1998), a mesma condição logística que Pederneiras, mas o complexo de terminais multimodais ainda não estava implantado em 1998. O que existia até então era apenas um terminal formado por instalações da Usina Diamante (processadora de cana-de-açúcar).

O diferente nível de aproveitamento de condições semelhantes em Pederneiras e Jaú gera um questionamento sobre o engajamento dos municípios do Vale na promoção do desenvolvimento. Especificamente quanto ao aproveitamento do potencial turístico tão amplamente divulgado, o que teria levado alguns municípios a implementarem alguma atividade de turismo e lazer (ainda que modesta, como é o caso de Porto Epitácio), ao longo dos reservatórios, enquanto em outros as idéias sequer chegaram ao papel? As entrevistas realizadas no departamento hidroviário, na CESP e em Piracicaba convergem para a idéia do interesse dos prefeitos associados a interesses privados e do governo estadual. O que é importante questionar é se esses interesses seriam resultados de um maior grau de comprometimento com o desenvolvimento ou, infelizmente, do clientelismo presente nas nossas instituições.

É importante notar que Pederneiras e Jaú estão inseridas em uma Região Administrativa (Bauru) que apresenta fatores locacionais que a colocam em condições

\footnotetext{
${ }^{15}$ Informações do sr. Egydio Mauro, ex-presidente da Câmara de Piracicaba.
} 
privilegiadas em relação a outras às quais estão inseridos os municípios lindeiros. A localização possibilitou o surgimento do único entroncamento hidro-ferro-rodoviário do trecho do rio Tietê da hidrovia (Pederneiras) e o interesse na formação de cooperativas para o aproveitamento dessa vantagem comparativa. Do total de quatro cooperativas criadas para o aproveitamento das oportunidades geradas pela hidrovia, duas encontramse nesta mesma região. Não seria exagero imaginar que essa região apresenta-se, no momento, provavelmente mais preparada para usufruir possíveis ganhos advindos da utilização da hidrovia Tietê-Paraná. Por outro lado, o fato de a partir dessa região, em direção ao rio Paraná, existir apenas uma cooperativa (sediada em Araçatuba), voltada ao aproveitamento da hidrovia, é um indicador da menor organização dos municípios para viabilizar o desenvolvimento através das oportunidades associadas à hidrovia.

Outra região cuja localização e aproveitamento dos rios tem importância histórica é Piracicaba. Entrevistas com lideranças municipais, bem como estudos sobre o aproveitamento das obras dos rios ressaltaram esse aspecto para justificar a realização das obras em Santa Maria da Serra. As condições naturais do distrito de Artemis Piracicaba são lembradas para justificar seu potencial para funcionamento como terminal de cargas. Nesse sentido, de acordo com os "defensores" da construção da barragem de Santa Maria da Serra, ela tornaria possível realizar hoje, com embarcações maiores e mais modernas, o que já funcionou no passado. A obra a ser realizada no município de Santa Maria da Serra possibilitará a chegada da hidrovia até Artemis, distrito de Piracicaba. O papel desempenhado pelo município de Piracicaba na história do transporte ao longo do rio Tietê também pode ser confirmado em Farrenberg (1998).

Apesar da importância histórica da navegação detectada em alguns municípios, os projetos de desenvolvimento encontrados para o Vale do Tietê-Paraná não preenchem as necessidades mínimas para um bom projeto, quando analisados pelo Método da Estrutura Lógica. É importante lembrar que esses projetos foram elaborados quando o método mencionado já era conhecido e utilizado por organismos financeiros internacionais para, através da análise dos pressupostos, avaliar os riscos existentes nesses projetos. Por serem relativamente recentes os projetos para o Vale do Tietê- 
Paraná e por não apresentarem indicadores objetivamente verificáveis (que possibilitariam avaliar seu êxito), não se pode afirmar com certeza que a frustração das expectativas existentes em tais projetos já estaria ocorrendo. Entretanto, há fortíssimos indícios sobre o não-cumprimento de pressupostos contidos nos projetos analisados.

À época em que foram elaborados os projetos de desenvolvimento para o Vale do Tietê-Paraná, analisados neste estudo, as obras nas hidrelétricas e na hidrovia já estavam prestes a serem encerradas, e, apesar disto, a região do Vale do Tietê-Paraná continuava relativamente menos desenvolvida que outras do Estado de São Paulo. O Índice de Desenvolvimento Humano (IDH) para os municípios do Vale do TietêParaná $^{16}$, em quase $80 \%$ dos municípios, é inferior à média do estado (São Paulo, 1999; Haddad \& Bonelli, 1998a). Esses valores foram calculados após o término da maioria das obras. Dessa forma, além da avaliação dos projetos voltados ao desenvolvimento regional e que em geral propõem novas alternativas para que a região se desenvolva (particularmente o turismo), é importante que se entendam as razões pelas quais o desenvolvimento esperado não ocorreu.

Os estudos sobre os municípios apresentados neste trabalho, embora tenham utilizado basicamente as mesmas fontes de dados, dificultam inferências quanto a possíveis diferenças entre os municípios, as quais possibilitariam maior ou menor aproveitamento das oportunidades geradas pelas obras no Vale do Tietê. Em geral, esses estudos utilizaram dados divulgados pelo Instituto Brasileiro de Geografia e Estatística (IBGE) e pela Fundação Sistema Estadual de Análise de Dados (Seade) e apresentaram discussões que sugerem carência de diferentes formas de capital.

Os projetos analisados indicam necessidade de investimentos em capital físico (principalmente na forma de infra-estrutura voltada ao turismo), capital humano (mais particularmente mão-de-obra especializada para atender às novas oportunidades de trabalho) e capital social (uma vez que há planos que sugeriram formação de associações e cooperativas). Com relação ao capital natural, a necessidade de recuperação de

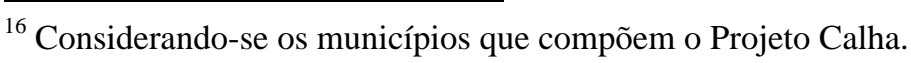


algumas áreas degradadas foi, em certos casos, mencionada. Quanto ao capital financeiro, constantemente os projetos tinham como pressuposto possíveis facilidades em atraí-lo para a região, mas as informações em geral eram vagas, limitando-se a citar a possibilidade de obtenção de linhas de crédito, uma vez que os municípios se engajassem na PNMT. Em suma, nos estudos para o Vale do Tietê-Paraná, há carência de informações mensuráveis e, portanto, comparáveis, verificada tanto na ausência de indicadores objetivos nos projetos elaborados quanto na falta de referência aos estoques de capitais disponíveis nos municípios. A importância da disponibilidade desses estoques para o desenvolvimento será discutida no próximo capítulo que apresenta os principais avanços da teoria econômica no que diz respeito ao desenvolvimento. 


\section{CONSIDERAÇÕES SOBRE O DESENVOLVIMENTO DO ESTADO DE SÃO PAULO}

Os trabalhos a serem apresentados a seguir têm por objetivo fornecer a base teórica necessária ao estudo de desenvolvimento regional. Assim, primeiramente serão apresentadas as principais teorias e idéias sobre o tema encontradas na literatura internacional. Em seguida, serão discutidos os trabalhos brasileiros, buscando identificar e analisar as teorias que mais fortemente influenciaram os estudiosos e, até mesmo, em alguns casos, as políticas formuladas no País. "Confrontando-se" os estudos desenvolvidos no Brasil, particularmente para o Estado de São Paulo, com os avanços teóricos existentes na literatura internacional, será possível definir adequadamente os objetivos específicos desta pesquisa.

\subsection{Crescimento, desenvolvimento econômico e regional}

\subsubsection{Os modelos de crescimento econômico e os estoques de capitais}

As teorias do crescimento econômico foram revisadas por Stern (1994). Esse autor discute as teorias dos anos de 1950 e 1960, nas quais aumentos na produção eram vistos como resultantes do acúmulo de capital, população e mudanças tecnológicas. Nesses modelos, apenas a tecnologia tinha potencial de gerar aumentos de longo prazo na produção per capita, uma vez que se pressupunham retornos constantes à escala. Essas teorias eram voltadas a explicar o crescimento dos países desenvolvidos, enquanto, para os países mais pobres era dada atenção à análise setorial, principalmente ao papel da agricultura no desenvolvimento. 
O modelo de Solow (1956) influenciou os modelos de crescimento econômico desenvolvidos nas décadas de 1950 e 1960. Esse modelo foi construído sobre os modelos de Harrod (1939) ${ }^{17}$ e Domar $(1946)^{18}$ e foram “o ponto de partida para teorias de crescimento endógeno" (Stern, 1994, p.52). A análise de Harrod relacionava equilíbrio entre poupança e investimento ao crescimento do capital. Assim, com o investimento correspondendo à taxa de crescimento do estoque de capital, a partir da igualdade entre poupança e investimento, chegou-se à “condição Harrod-Domar”. Numa das versões dessa condição, a taxa de crescimento da produção $(Y / Y)$ é a relação entre a taxa de poupança $(s)$, que é uma fração da renda, e a variação da taxa de crescimento da relação capital-produto $(v) .{ }^{19}$ No modelo de Solow, entretanto, independentemente do valor de $s$, a economia cresce à taxa de crescimento da população no longo prazo. Ao assumir retornos constantes à escala na produção, ressalta Stern, Solow considerou que a taxa de crescimento da produção de longo prazo era essencialmente a mesma que aquela do fator trabalho, e, portanto, o produto per capita seria constante no longo prazo.

A expansão do modelo de Solow permitiu a inclusão do progresso tecnológico na análise. Em geral, esta “inclusão” era feita através de mudança na função de produção. A utilização de um parâmetro tecnológico, como indicado em Sachs \& Larrain (1995), multiplicando apenas o fator trabalho, possibilita a análise. A idéia é bastante simples e consiste em atribuir ao progresso tecnológico a elevação da produtividade do trabalhador. O trabalho efetivo é o resultado da multiplicação desse parâmetro com o insumo mão-de-obra. Logo, as unidades de trabalho efetivas cresceriam a taxas superiores ao crescimento da mão-de-obra, mais precisamente, à soma das taxas de crescimento da mão-de-obra e da variação tecnológica. Nesse tipo de modelo, ampliado para incluir progresso tecnológico, ressalta Stern (1994), o produto per capita cresce, no longo prazo, à taxa do progresso tecnológico de "Harrod-neutral".

\footnotetext{
${ }^{17}$ HARROD, R.F. An essay in dynamic theory. Economic Journal, v.49, p.14-33, 1939.

${ }^{18}$ DOMAR, E. Capital expansion, rate of growth and employment. Econometrica, April 1946.

${ }^{19}$ Onde $v=\dot{K} / \dot{Y}$.
} 
A descrição do modelo de Solow é encontrada em livros textos de macroeconomia, por exemplo, na obra de Sachs \& Larrain (1995), na qual é apresentada de maneira bastante didática. Para dividir o crescimento da produção econômica (Q) entre fatores básicos de crescimento (capital, trabalho e tecnologia), Solow supôs uma forma especial de mudança tecnológica em que as variações de tecnologia (T) causam igual aumento no produto marginal do capital $(\mathrm{K})$ e do trabalho $(\mathrm{L})$. Isto é verdadeiro quando a função de produção é escrita na forma especial, apresentada em Sachs \& Larrain:

\section{$Q=T f(K, L)$,}

onde $\boldsymbol{f}(\boldsymbol{K}, \boldsymbol{L})$ é uma função neoclássica de produção normal em termos do capital $(\mathbf{K})$ e mão de obra $(\mathbf{L})$. Supondo-se que a população e a força de trabalho são os mesmos, e, portanto, o produto per capita e o produto por trabalhador sejam iguais, chega-se ao produto per capita como uma função crescente da proporção capital/trabalho. Para tanto, divide-se a função $\mathbf{Q}$ por $\mathbf{L}$, obtendo-se:

$$
q=\boldsymbol{T} \boldsymbol{f}(\boldsymbol{k})
$$

onde $q=Q / L$ e $k=K / L$

A variação no estoque de capital (que corresponde ao investimento menos a depreciação) relaciona-se à poupança através da igualdade entre investimento e poupança, na representação original de Solow. Nessa, de acordo com Sachs \& Larrain (1995), a economia era fechada. Outros pressupostos do modelo são, conforme mencionado anteriormente, progresso tecnológico zero (inicialmente), crescimento populacional proporcional constante e igual ao crescimento da força de trabalho. Como resultado, tem-se que a equação fundamental de acumulação de capital ( $\Delta \boldsymbol{k})$ é a taxa de poupança per capita $(\boldsymbol{s q})$, subtraindo-se o termo $(\boldsymbol{n}+\boldsymbol{d}) \boldsymbol{k}$, onde $\boldsymbol{n}$ é a taxa de crescimento proporcional da população, $\boldsymbol{d}$ é a depreciação do estoque de capital e $\boldsymbol{k}$ é o capital por 
unidade de mão-de-obra. Da análise desta relação e do conceito de estado estável ${ }^{20}$, surgiram as conclusões importantes relacionadas a crescimento e poupança. Não importa qual o valor de $\boldsymbol{s}$, a economia cresce à taxa $\boldsymbol{n}$ no longo prazo; entretanto, no curto prazo, a taxa de poupança pode afetar a taxa de crescimento. O que é afetado, no longo prazo, pela taxa de poupança é a renda per capita no estado estável.

Após a fase de modelos influenciados pelo trabalho de Solow, outros autores passaram a considerar o crescimento determinado "endogenamente". Stern (1994) cita os modelos de crescimento endógeno de Romer (1986 e 1990) ${ }^{21}$, de Lucas (1988), entre outros, e considera uma volta às preocupações anteriores relacionadas ao progresso tecnológico, mas agora este é tratado "endogenamente". Essa evolução teórica pode ser vista como variações dos trabalhos de Arrow $(1962)^{22}$ e Uzawa (1965) ${ }^{23}$. Sobre os modelos endógenos, Stern sintetiza:

"A intenção foi construir modelos nos quais o crescimento do produto per capita no longo prazo não seja exógeno, mas cresça como resultado de decisões de agentes e políticas de governos. O crescimento, nesses modelos, vem, em geral, de duas fontes, externalidades no processo de investimento (aprender fazendo ou aprender assistindo, na tradição de Arrow, 1962) ou investimento em atividades produtoras de conhecimento. Alguns desses processos inerentemente envolvem imperfeições de mercado e novas teorias microeconômicas (ver, por exemplo, Tirole, 1988) têm sido valiosas em integrar essas imperfeições a esses modelos" (Stern, 1994, p. 2-3).

\footnotetext{
${ }^{20}$ Nesse estado, $\boldsymbol{k}$ e $\boldsymbol{q}$ estão em um nível permanente. Para ser atingido, a poupança per capita precisa ser exatamente igual a $(\boldsymbol{n}+\boldsymbol{d}) \boldsymbol{k}$, de modo que $\boldsymbol{\Delta} \boldsymbol{k}=0$ (Sachs e Larrain, 1995, p.633).

${ }^{21}$ ROMER, P. Increasing returns and long-run growth. Journal of Political Economy, v.94, p.10021037, 1986/ROMER, P. Endogenous technical change. Journal of Political Economy, v.98, p.S71-S102, 1990.

${ }^{22}$ ARROW, K.J. The economic implications of learning by doing. Review of Economic Studies; v.29, p.155-173, 1962.

${ }^{23}$ UZAWA, H. Optimum technical change in an aggregative model of economic growth. International economic review, v.6, p.18-31, 1965.
} 
O capital financeiro também foi incluído em modelos de crescimento econômico. Fry (1995) revisa a incorporação desse capital nesses modelos, dentre eles, o de Tobin $(1965)^{24}$, no qual as unidades econômicas alocam sua riqueza entre dois ativos (moeda e capital produtivo). Tobin usou o modelo de Solow, já mencionado. A escolha do modelo de crescimento, de acordo com Fry, tem influência crucial sobre a análise dos efeitos do capital financeiro sobre o crescimento econômico. Para exemplificar essa importância, cita o uso da função Cobb-Douglas e do modelo Harrod-Domar. A análise através da função Cobb-Douglas, dados os pressupostos do modelo, levam a um efeito apenas temporário sobre a taxa de crescimento econômico em resposta a condições financeiras que alterem a quantidade de poupança e investimento. No modelo HarrodDomar, sabe-se que um aumento na taxa de poupança-investimento eleva a taxa de crescimento permanentemente. Além desses modelos de crescimento, também aqueles de crescimento endógeno são mencionados por Fry. Depois dos avanços já apresentados, esses modelos significaram a possibilidade de assumir que o produto marginal do capital não diminuiu para a economia como um todo. Portanto, eliminou-se a limitação existente nos primeiros modelos de desenvolvimento financeiro nos quais os retornos marginais para o capital eram constantes.

O capital financeiro caracteriza-se por sua "volatilidade". Essa característica do capital financeiro foi devidamente incorporada nos modelos neoclássicos de crescimento endógeno, graças à possibilidade de considerar-se o produto marginal do capital decrescente. Esses modelos atribuem um papel muito mais importante ao capital financeiro no processo de crescimento. A produtividade marginal decrescente desse capital é o incentivo para a sua transferência de países ricos para os países pobres. $\mathrm{O}$ capital financeiro flui “dos países mais ricos para os países mais pobres com retornos marginais mais altos para o capital. Entretanto, este fluxo pode exercer apenas um efeito temporário sobre as taxas de crescimento dos países pobres”( Krugman, 1993, citado por Fry, 1995, p. 14).

${ }^{24}$ TOBIN, J. Money and economic growth. Econometrica, v.33, n.4, p.671-684, 1965. 
Os modelos de McKinnon (1973) ${ }^{25}$ e Shaw $(1973)^{26}$ foram fundamentais para o esclarecimento do papel do capital financeiro para o desenvolvimento. De acordo com Fry (1995), o argumento central desses autores é que a repressão financeira reduz a taxa real de crescimento econômico. Para Shaw (1973), citado por Fry (1995), em todos os casos que estudou, a estratégia de reprimir o sistema financeiro através de distorções indiscriminadas nos preços dos serviços financeiros (inclusive taxa de juros), estacionou ou atrasou gravemente o processo de desenvolvimento. Deve-se ressaltar que essa visão do sistema financeiro surgiu com os trabalhos de McKinnon e Shaw, que são descritos em Fry (1995). A importância desses estudos reside em rejeitar idéias contidas nos modelos anteriores. Segundo Fry, os dois autores argumentaram que os pressupostos básicos de modelos keynesianos e dos economistas estruturalistas eram inadequados no contexto de países em desenvolvimento. Tanto McKinnon quanto Shaw formalizaram suas idéias e mostraram que "repressão financeira reduz tanto a quantidade quanto a qualidade de investimento nas economias como um todo" (Fry, 1995, p.38).

As formas de capital consideradas nas teorias de crescimento econômico eram, inicialmente, três: capital físico, capital financeiro e capital natural. A importância desse último foi desconsiderada pelo próprio Solow e outros autores neoclássicos, conforme Prugh (1995). A ênfase dos modelos de crescimento, portanto, era para capital físico e financeiro. A ausência do primeiro, "especialmente infra-estrutura, foi inicialmente apontada como obstáculo crítico ao desenvolvimento (Mandelbaum, 1945; Rosenstein Rodan, 1943; Nurske, 1952, Lewis, 1954, 1955)" (Banco Mundial, 1991, p.39). Além da infra-estrutura, também estão incluídas no conceito de capital físico máquinas, equipamentos e benfeitorias, que fazem parte do processo produtivo. Sua importância foi amplamente enfatizada para o desenvolvimento. Mais recentemente, detectou-se a complementaridade existente entre esta forma de capital e o capital humano. Essa relação foi verificada por Lucas (1988) e, associada ao avanço tecnológico, tornou-se extremamente importante.

\footnotetext{
${ }^{25}$ McKINNON, R.I. Money and capital in economic development. Washington: Brookings Institution, 1973.

${ }^{26}$ SHAW, E.S. Financial deepening in economic development. New York: Oxford University Press, 1973.
} 
A distinção entre as formas de capital físico e financeiro não foi tão óbvia para os primeiros teóricos do assunto. Para autores clássicos, capital era visto como estoque previamente acumulado de trabalho anterior, conforme pode ser verificado em Stuart Mill (1996), ou em trechos da obra de Ricardo (1996). Esse último, em "Princípios de Economia Política e Tributação", ao discutir a renda da terra, afirma que menos capital é o mesmo que menos trabalho. Stuart Mill dedicou um capítulo de "Princípios de Economia Política", intitulado "O capital", direcionado à definição de capital como estoque previamente acumulado de trabalho anterior. $\mathrm{O}$ conceito apresentado era necessariamente vinculado à produção. Tudo o que fosse destinado a assegurar os pré-requisitos ao "trabalho produtivo" constituiria capital. Nessa linha de raciocínio, esse autor incluía, além da cobertura, proteção, ferramentas e materiais necessários, também a alimentação e manutenção dos trabalhadores durante o processo, diferenciando capital de posses destinadas a uso "improdutivo". Esses usos seriam, por exemplo, aquisição de jóias, objetos de ouro e prata ou gastos com divertimento. Stuart Mill considerou a possibilidade de existência de capital não empregado. Incluiu, nesse caso, capital cujo emprego estaria sendo procurado, mercadorias não vendidas (e, portanto, ainda sem uso produtivo), ou ainda circunstâncias anteriores ao início da produção em casos de necessidade de realizar determinados pagamentos (impostos sobre matéria prima ou pagamento adiantado da renda da terra, ou ainda para pagamento da parte dos salários que não correspondesse àquela efetivamente necessária à subsistência e saúde dos trabalhadores). Nota-se, portanto, que a preocupação com capital físico e financeiro é mais tradicional nos estudos. O capital natural, analisado sob o título de "terra", embora tenha despertado interesse desde os clássicos, perdeu importância para explicar o desenvolvimento com o avanço tecnológico.

O capital natural é "uma extensão da tradicional noção econômica de capital, que é geralmente definida como meios de produção manufaturados, isto é, máquinas, equipamentos, ferramentas, construções, etc." (Prugh, 1995, p.51). A importância fundamental exercida pelas características naturais (especificamente a fertilidade do solo), para a renda da terra (mas não sobre o valor relativo das mercadorias), foi 
reconhecida por Ricardo. Entretanto, o conceito de capital, para ele e seus contemporâneos, ainda era restrito à idéia de manufaturado e determinado pela quantidade de trabalho. Ricardo discutiu o problema do "capital" associado ao cultivo da terra e observou que, muitas vezes, antes de entrarem em cultivo as terras inferiores, o “capital” era empregado mais produtivamente naquelas já em uso. Nota-se, portanto, que comparava o retorno de se elevar o "capital" na terra boa ou cultivar terras piores. Hoje parece claro que a análise de Ricardo tratava de capital físico, financeiro e natural.

As origens da visão econômica do capital natural foram revisadas por Prugh (1995). Essa forma de capital estaria reduzida ao fator de produção terra que, juntamente com capital e trabalho, compunha o quadro de fatores de produção. $\mathrm{O}$ autor menciona a industrialização como um advento a partir do qual diminuiu a importância da terra em relação aos outros dois fatores nos estudos de teoria econômica. Prugh discute as visões sobre capital natural (ou simplesmente do fator de produção terra) nos autores clássicos e na Escola Neoclássica. Prugh entende que as condições que permitiram a evolução da escola neoclássica (por exemplo, uma população bem pequena para vastos recursos naturais disponíveis) não existem mais, e, portanto, sugere uma perspectiva de economia ecológica.

Apesar da importância crucial do capital natural para os estágios iniciais de desenvolvimento das economias e de uma preocupação relativamente recente com a escassez de recursos naturais, esse estoque de capital perdeu o poder de explicar o crescimento econômico com a evolução da tecnologia. "Em geral, os estudos econômicos sobre desenvolvimento concluem que a abundância (ou ausência) de recursos naturais não foram um fator importante para o crescimento econômico" (Sachs \& Larrain, 1995, p. 623). De acordo com Prugh (1995), autores neoclássicos estariam assumindo que o capital "feito pelo homem" substituiria os recursos naturais. O próprio Solow, segundo Prugh, teria minimizado a importância do capital natural de maneira bastante radical. Posteriormente, Solow teria moderado sua opinião, ao contrário de outros autores neoclássicos. Em síntese, durante muitos anos, predominou a idéia de que os materiais e serviços fornecidos pelo ambiente não eram indispensáveis. Os modelos 
utilizados para explicar o crescimento econômico foram elaborados por autores cuja visão é justamente esta criticada por Prugh. Nos anos de 1990, a preocupação com o capital natural aumentou; houve uma recuperação do prestígio de estudos que abordam os recursos naturais provocada pela possibilidade de esgotamento desses. Entretanto, há dificuldades quanto à avaliação de seus estoques, uma vez que as medidas utilizadas para crescimento econômico (PIB e PIB per capita) não têm por finalidade contemplar essa forma de capital.

Com a evolução dos modelos explicativos do crescimento econômico, detectou-se o papel do capital humano nesse processo. De acordo com Stern (1994), inicialmente essa forma de capital recebeu atenção insuficiente na literatura, mas teorias mais novas de crescimento, focalizam este importante fator do processo de crescimento. O modelo de Lucas (1988), dentre outros modelos de crescimento endógeno discutidos por Stern, é da maior importância para os estudos sobre capital humano. Tanto a função de produção desse modelo quanto a utilizada por Uzawa (1965) pode ser representada como:

$$
Y=F(K, u h L)
$$

“onde $\boldsymbol{u}$ é a fração de tempo dedicada ao trabalho (não-lazer), $\boldsymbol{h}$ é a produtividade do tempo de trabalho. O investimento aumenta tanto o estoque de trabalho $\boldsymbol{k}$ quanto aumenta a produtividade do tempo dedicado ao trabalho. (...) $\mathrm{O}$ acréscimo na produtividade pode ser interpretado tanto como a dedicação ao trabalho para educação, que aumenta a produtividade de modo linear, ou como a alocação de recursos para novos processos que atuam para aumentar a produtividade do trabalho" (Stern, 1994, p.67).

Sen (2000) menciona o capital humano com a finalidade de comparar a abordagem que propõe para o desenvolvimento econômico nos estudos mais recentes sobre crescimento econômico. A abordagem de Sen é mais ampla e será discutida a seguir. De acordo com o autor, os estudos sobre capital humano foram freqüentemente 
influenciados por experiências empíricas, dentre elas, as asiáticas. Esse fato pode ser observado também no trecho a seguir:

"O papel do capital humano tornou-se especialmente claro na experiência das economias do Leste asiático, que investiam fortemente em educação e treinamento. Pesquisas sobre a produtividade da educação esclareceram o vínculo entre capital humano e desenvolvimento (Schultz, 1961; Becker, 1964). Em toda essa obra, o acúmulo de capital humano desponta como um dos mais poderosos motores do desenvolvimento" (Banco Mundial, 1991, p. 39).

\title{
3.1.2 Crescimento e desenvolvimento econômico
}

Crescimento econômico e desenvolvimento foram amplamente discutidos por Sen (2000), em vasta revisão sobre o tema:

\begin{abstract}
"Uma concepção adequada de desenvolvimento deve ir muito além da acumulação de riqueza e do crescimento do Produto Nacional Bruto e de outras variáveis relacionadas à renda. Sem desconsiderar a importância do crescimento econômico, precisamos enxergar muito além dele" (Sen, 2000, p.28).
\end{abstract}

O autor amplia o conceito de desenvolvimento para um "processo de expansão das liberdades reais que as pessoas desfrutam”, e, nesse sentido, o “crescimento do PNB, ou das rendas individuais, pode ser muito importante como meio de expandir tais liberdades" (Sen, 2000, p.17). A carência de oportunidades econômicas é uma das principais fontes de privação de liberdade. Outras seriam: pobreza e tirania, destituição social sistemática, negligência dos serviços públicos e intolerância de Estados repressivos. Vários são os exemplos ao longo do livro para esclarecer a relação existente entre o desenvolvimento e essas fontes de privação que existem mesmo em países considerados desenvolvidos pelo critério da renda . Outra relação importante discutida pelo autor diz respeito à renda per capita e longevidade. Para analisar esta 
relação, o autor citou o estudo de Anand \& Ravallion (1993) ${ }^{27}$, e sintetizou os resultados no trecho transcrito a seguir:

"Com base em comparações entre países, esses autores constataram que a expectativa de vida realmente tem uma correlação significativamente positiva com o PNB per capita, mas essa relação funciona sobretudo por meio do impacto do PNB sobre (1) as rendas, especificamente dos pobres, e (2) os gastos públicos com serviços de saúde em especial. Assim que essas duas variáveis são incluídas pouca explicação adicional pode ser obtida incluindo-se o PNB per capita como influência causal adicional. Com a pobreza e os gastos públicos com saúde como variáveis explicativas por si mesmas, a relação entre PNB per capita e a expectativa de vida parece (na análise de Anand \& Ravallion) desaparecer por completo" (...) (Tal resultado) "se corroborado também por outros estudos empíricos, não demonstraria que a expectativa de vida não se eleva com o crescimento do PNB per capita, mas indicaria que a relação tende a funcionar particularmente por meio do dispêndio público com serviços de saúde e por meio do êxito na eliminação da pobreza. O principal é que o impacto do crescimento econômico depende muito do modo como seus frutos são aproveitados" (Sen, 2000, p.61).

Sen discute duas visões do processo de desenvolvimento existente tanto na análise econômica realizada por profissionais quanto nas discussões e debates públicos. A primeira delas assemelha-se muito a discursos de governos autoritários do Brasil, durante os anos de crescimento econômico, e de outros países em desenvolvimento. Nessa visão, o desenvolvimento seria:

${ }^{27}$ ANAND, S. ; RAVALLION, M. Human development in poor countries: on the role of private incomes and public services. Journal of Economic Perspectives v.7, 1993. 
"um processo "feroz", com muito "sangue, suor e lágrimas" - um mundo no qual sabedoria requer dureza e calculadamente são negligenciadas várias outras preocupações vistas como "frouxas", por exemplo existência de redes de segurança social para proteger os pobres, fornecimento de serviços sociais para a população e o favorecimento "cedo demais" de direitos políticos e civis e o "luxo" da democracia. Essas coisas, adverte-se com pose austera, podem vir a ser favorecidas posteriormente, quando o processo de desenvolvimento houver produzido frutos suficientes; o necessário aqui e agora é “dureza e disciplina" (Sen, 2000, p.51).

$\mathrm{Na}$ segunda visão de desenvolvimento apresentada por Sen, o desenvolvimento consistiria em um "processo amigável”. Essa característica seria constatada, por exemplo nas trocas mutuamente benéficas, ou na atuação de redes de segurança social ou em liberdades políticas ou de desenvolvimento social, ou ainda por alguma combinação dessas atividades que o autor considerou sustentadoras. Sua abordagem, segundo o próprio autor, estaria mais próxima dessa última, uma vez que nesta é a expansão de liberdade o fim primordial e o meio principal do desenvolvimento. ${ }^{28}$

Sen (2000) utiliza-se de dados empíricos para ilustrar a importância da abordagem que propõe em seu livro, e, em alguns casos, o Brasil é citado. A importância da visão da liberdade como desenvolvimento é ilustrada com um exemplo onde o Brasil, Gabão, África do Sul e Namíbia são comparados a outro grupo de países bem mais pobres em termos de PNB per capita (Sri Lanka, China ou o Estado de Kerala, na Índia), mas com expectativas de vida bem mais elevadas. Há outros trechos em que o

\footnotetext{
${ }^{28}$ Esses dois "papéis" da liberdade no desenvolvimento são nomeados por Sen, respectivamente, "papel constitutivo" e "papel instrumental". Esse último refere-se a liberdades e direitos que contribuem para o progresso econômico, enquanto o primeiro "relaciona-se à importância da liberdade substantiva no enriquecimento da vida humana. As liberdades substantivas incluem capacidades elementares como por exemplo ter condições de evitar privações como fome, subnutrição, a morbidez evitável e a morte prematura, bem como as liberdades associadas a saber ler e fazer cálculos aritméticos, ter participação política e liberdade de expressão etc." (Sen, 2000, p.52).
} 
autor refere-se ao Brasil "onde a criação de oportunidades sociais tem sido muito lenta, tornando-se assim uma barreira para o desenvolvimento econômico" (Sen, 2000, p.62). O contraste dos países do Leste e Sudeste Asiático com países como Brasil que apresentaram um crescimento do PNB per capita quase comparável é nítido, pois esses últimos têm uma "longa história de grave desigualdade social, desemprego e descaso com o serviço público de saúde" (Sen, 2000, p.62). É importante ressaltar que, do ponto de vista da liberdade dos indivíduos, para ter uma vida longa e viver bem, o caminho a ser percorrido pelo País rumo ao desenvolvimento seria mais longo que a mera análise pelo PNB per capita e em desvantagem em relação a países do Leste e Sudeste Asiático.

Além de introduzir uma nova perspectiva para o estudo do desenvolvimento, Sen discute os diferentes sistemas avaliatórios. Renda e riqueza, os critérios mais utilizados na literatura econômica, precisam ser integradas a um quadro mais amplo. Apesar das conexões existentes entre renda e as "capacidades" (capabilities) das pessoas de levar o tipo de vida que, com razão, valorizam tais conexões, de acordo com Sen, não são tão fortes assim. Privação de capacidades elementares pode refletir em mortalidade prematura, subnutrição, morbidez persistente, analfabetismo e outras deficiências. Logo, é importante que se veja a pobreza como uma privação de capacidades básicas e não apenas como baixa renda, e, para tanto, há necessidade de uma base informacional mais adequada. Assim, é necessário outra abordagem que, conforme discutido amplamente pelo autor, difere também do enfoque utilitarista (voltado à satisfação mental), do libertarismo e da justiça rawlsiana.

As "liberdades substantivas", os direitos e a qualidade de vida, no utilitarismo, de acordo com Sen, podem ter apenas um papel indireto sobre uma avaliação normativa por meio de seus efeitos sobre a utilidade. Isso ocorre tanto no utilitarismo clássico (no qual a utilidade é definida como prazer, felicidade ou satisfação), quanto em suas formas mais modernas. Como a mente humana ajusta seus desejos e habilidades às circunstâncias, principalmente para tornar a vida suportável em condições adversas, a "medida mental do prazer ou do desejo é maleável demais para constituir-se em um guia confiável para a privação e desvantagem” (Sen, 2000, p.82). 
Mesmo nas formas mais modernas do utilitarismo, nas quais a utilidade geralmente é vista pela representação do comportamento de escolha, a indiferença às liberdades substantivas, direitos e liberdades formais ${ }^{29}$ permanece. É uma vantagem tratar a utilidade como uma representação da preferência de uma pessoa por não exigir comparações mentais, mas, em contrapartida, impede comparações interpessoais. A indiferença distributiva, o descaso com os direitos, liberdades e a adaptação e condicionamento mental são limitações da perspectiva utilitarista. Logo, há necessidade de uma base informacional mais ampla e, para o autor, concentrada na capacidade de as pessoas escolherem a vida que elas, com justiça, valorizam.

Ao buscar uma teoria de base informacional mais ampla, Sen discutiu a análise de John Raws (que considera, sob muitos aspectos, a mais importante das teorias contemporâneas de justiça) e a teoria libertária de Robert Nozick. Sobre a clássica teoria de justiça de S. J. Raws, baseada em bens primários ${ }^{30}$, Sen concluiu que, ampliar o enfoque informacional de rendas para tais bens, não seria adequado "para lidar com todas as variações relevantes na relação entre renda e recursos, de um lado, e bem-estar e liberdade de outro" (Sen, 2000, p.93). As limitações apresentadas seriam as mesmas que a avaliação do bem-estar pela renda e mercadoria, ou seja, heterogeneidades pessoais, diversidades ambientais, mudança no clima social, diferenças de perspectivas relativas e distribuição da renda na família. Todos esses itens foram discutidos como fontes de variação de rendas reais e das vantagens obtidas (bem-estar e liberdades). Sen concluiu que a base do libertarismo é muito limitada. Em relação à formulação teórica de Nozick $^{31}$, embora mais moderna que a de Rawls, as críticas do autor são, quanto à radicalização que existe por trás dessas idéias:

29 "Liberdades formais" foi o termo encontrado pelo tradutor para liberties usado por Sen para indicar os
chamados direitos individuais, ou seja, "a liberdade que cada um tem de não ser tolhido no exercício de
suas faculdades ou direitos, exceto nos casos em que a lei o determina" (Sen, 2000 , p.75 - nota de rodapé).
30 "Os bens primários são meios de uso geral que ajudam qualquer pessoa a promover seus próprios fins,
como 'direitos, liberdades e oportunidades, renda e riqueza e as bases sociais do respeito próprio"” (Sen,
2000 , p.92, baseado em RAWS, J. A theory of justice, 1971.).
31 NOZICK, R. Anarchy, state, and utopia. 1974.; e NOZICK, R. The examined life. New York: Simon \& Schuster, 1989. 
"A prioridade inflexível dos direitos libertários pode ser particularmente problemática, pois as conseqüências reais da operação desses intitulamentos ${ }^{32}$ podem incluir resultados terríveis. Em particular, pode conduzir à violação da liberdade substantiva dos indivíduos para realizar as coisas às quais eles têm razão para atribuir enorme importância, como escapar à mortalidade evitável, ser bem nutrido e sadio e saber ler, escrever e contar etc. A importância dessas liberdades substantivas não pode ser descartada com a justificativa da 'prioridade da liberdade formal'”(Sen, 2000, p.85).

Após discutir os sistemas avaliatórios, Sen apresenta a sua proposta, na qual o "espaço" não é o de utilidades nem de bens primários, mas sim o das liberdades substantivas - as capacidades de escolher uma vida que se tem razão para valorizar. Duas definições são necessárias para entender sua abordagem: funcionamentos e capacidade.

“O conceito de 'funcionamento' (...) reflete as várias coisas que uma pessoa pode considerar valioso fazer ou ter. Os funcionamentos valorizados podem variar dos elementares (ser adequadamente nutrido e livre de doenças evitáveis), atividades ou estados pessoais muito complexos, como participar da vida da comunidade e ter respeito próprio" (Sen, 2000, p.95).

“A 'capacidade' [capability] de uma pessoa consiste nas combinações alternativas de funcionamentos cuja realização é factível para ela. Portanto é um tipo de liberdade: a liberdade substantiva de realizar combinações alternativas de funcionamentos (ou, menos formalmente expresso, a liberdade de ter estilos de vida diversos)" (Sen, 2000, p.95).

\footnotetext{
${ }^{32}$ Do inglês entitlement empregado por Sen, nesse contexto, ou seja, "conjunto de pacotes alternativos de bens que podem ser adquiridos mediante o uso de vários canais legais de aquisição facultados a essa pessoa" (Sen 2000, p.54).
} 
Um dos principais méritos da abordagem de Sen, apontados pelo próprio autor, é tratar questões de julgamento de um modo explícito. Cada indivíduo teria um conjunto capacitório formado pelos vetores de funcionamento alternativos à sua escolha. $\mathrm{O}$ enfoque utilizado na literatura tem sido sobre os funcionamentos realizados ou sobre $\mathrm{o}$ conjunto capacitário de alternativas da pessoa ou ainda uma combinação dessas versões. Quanto ao conjunto capacitário, é "possível atribuir importância a ter oportunidades que não são aproveitadas (...) escolher por si só pode ser considerado um funcionamento valioso" (Sen, 2000, p.96). O autor reconhece as dificuldades existentes na abordagem da "capacidade" ("inescapavelmente pluralista"), mas supor a existência de homogeneidade, como na análise utilitarista, seria, para ele, fechar os olhos à condição humana de criaturas racionais. Embora a heterogeneidade seja considerada também na análise rawlsiana, a abordagem da capacidade é informacionalmente mais rica. $\mathrm{O}$ autor ressalta a necessidade de explicitar os valores implícitos e discute formas práticas para "abordagem da capacidade".

Sen deixa muito claro que suas preocupações com a ampliação do conceito de desenvolvimento encontram respaldo em vários autores. Recorre a Aristóteles para indicar a inadequação de se adotar como objetivo básico apenas a maximização da renda ou da riqueza ou considerar o crescimento econômico como um fim em si mesmo. Cita autores que discutiram a questão e conclui:

"O desenvolvimento tem de estar relacionado sobretudo com a melhora de vida que levamos e das liberdades que desfrutamos. Expandir as liberdades que temos razão para valorizar não só torna nossa vida mais rica e mais desimpedida, mas também permite que sejamos seres sociais mais completos, pondo em prática nossas volições, interagindo com o mundo em que vivemos e influenciando esse mundo" (Sen, 2000, p.29).

Embora Adam Smith seja a principal influência sobre o teor do livro de Sen, este autor distingue os problemas atacados por Smith das questões atuais. Por exemplo, a 
base racional do mecanismo de mercado não está voltada a bens públicos e problemas de segurança social, mas, sim, à análise de bens privados. A postura do autor quanto aos mecanismos de mercado leva-o a discutir os bens públicos, para os quais reconhece ser necessária uma abordagem múltipla. ${ }^{33}$ Além da necessidade de abordagem múltipla para os bens públicos, também se enquadram nesse contexto as questões de segurança social. Com as particularidades dos problemas atuais em relação àqueles analisados por Adam Smith em mente, os papéis do Mercado e do Estado foram amplamente discutidos. Outros aspectos importantes tratados por Sen, dentre eles o papel da democracia, também foram estudados por outros autores e serão discutidos oportunamente. Antes disso, é necessário conhecer outras teorias importantes sobre desenvolvimento a fim de se verificar como as idéias apresentadas por Sen e outros autores contemporâneos respondem a questões não devidamente explicadas anteriormente.

As tentativas de explicar os diferentes graus de desenvolvimento existentes entre regiões foram várias, e uma delas, utilizada há mais tempo pelos pesquisadores do assunto, baseia-se nas chamadas vantagens comparativas. A Escola Alemã teve como base essas idéias. O pioneiro nessas análises foi Von Thünen, nos fins do século XVIII e início do século XIX. Von Thünen investigou problemas associados à agricultura, antecipando, de acordo com Eckelund Jr. \& Hebert (1975) conceitos importantes: renda econômica, retornos decrescentes, custos de oportunidade e teoria da distribuição da produtividade marginal. Foi o pioneiro da teoria da locação.

As bases para o desenvolvimento da análise locacional são apresentadas no trabalho "O Estado Isolado" de Von Thünen, publicado em $1826 .{ }^{34}$ De acordo com Eckelund Jr \& Hebert (1975), esse trabalho referia-se a problemas práticos para encontrar meios para conduzir a agricultura de modo mais lucrativo. Isso significava descobrir as leis que determinam os preços de produtos agrícolas e as leis pelas quais mudanças nestes eram transformadas em padrões de uso da terra. Assim como Ricardo,

${ }^{33}$ É interessante a percepção do autor sobre a educação básica como um bem semi-público, pois, além do benefício individual obtido por quem a recebe, é compartilhado pela comunidade, e, portanto, a expansão geral da educação e alfabetização em uma região podem favorecer a mudança social.

${ }^{34}$ VON THÜNEN, J. H. Isolated State. Trad. de Carla Wartenberg. Oxford: Pergamon Press, 1966. 
Von Thünen reorganizou as diferenças de custo de produção resultantes da utilização da terra de diferente qualidade e localização, concentrou-se nas diferenças da localização e não na fertilidade do solo. Para encontrar um sistema de utilização mais lucrativo, expressou seus argumentos em uma construção teórica que, de acordo com Eckelund Jr. \& Hebert, caracterizava-se por uma grande cidade (que de fato seria o único mercado) no centro de uma planície cujo único transporte fosse por terra. Outras características importantes eram a igualdade de fertilidade do solo dentro da planície e a inexistência de vantagem comparativa de produção entre os pontos, exceto a distância em relação à cidade. Assim, trabalho e capital seriam igualmente produtivos em qualquer localização, e o custo de produção por área de determinado produto é o mesmo em qualquer lugar.

O modelo de uso da terra de Von Thünen consistia em uma série de anéis (círculos concêntricos) ao redor do mercado, e a distância deste ao local de produção é que determinaria o que produzir dentro de cada região. A renda da terra e as distâncias da fazenda à cidade são os únicos fatores variáveis. Quando se move para mais distante da cidade, a renda da terra cai devido à localização relativa, enquanto os custos de transporte se elevam. Reconheceu que os produtos volumosos são mais caros para transportar, e ainda produtos mais perecíveis não poderiam permanecer longo período em trânsito. Suas idéias, devidamente adaptadas, foram posteriormente utilizadas inclusive para planejamento de solo urbano.

Ferreira (1989b) faz uma revisão sobre as teorias da localização e a organização espacial da economia. Quanto à instalação de atividades econômicas em determinadas regiões e a ausência dessas atividades em outras, sintetiza:

“Os fatores locacionais clássicos têm significativo poder de explicação das vantagens e desvantagens gerais e específicas de cada atividade sócio-econômica, que as regiões têm para atrair empreendimentos (...). A distribuição das indústrias entre as regiões, particularmente as de pequeno e médio tamanhos agrícolas, industriais e comerciais, são influenciadas pela distribuição dos recursos naturais, pelas condições 
edafológicas, pelos custos de transportes e por outros fatores locacionais modernos que afetam as decisões da localização das indústrias de alta tecnologia" (Ferreira, 1989b, p.196).

Existe uma tendência a certas atividades econômicas se desenvolverem sob influência de pólos. Essa tendência deve-se às chamadas "economias de aglomeração" que, de acordo com Bos (1965), citado por Ferreira (1989a) ${ }^{35}$, podem ser de várias categorias, sendo a maior parte delas devido a efeitos de escala ou indivisibilidade.

“As questões referentes à concentração e dispersão das atividades (...) chamam a atenção para a tendência à aglomeração das atividades produtivas. Este fenômeno estrutural assume papel de grande relevância na compreensão das disparidades de desenvolvimento econômico entre regiões" (Ferreira, 1989a, p.59).

A partir dos estudos da tendência à aglomeração das teorias clássicas da economia espacial ${ }^{36}$, de acordo com o autor mencionado, François Perroux ${ }^{37}$, desenvolveu seu trabalho, tornando-se o principal divulgador das teorias de desenvolvimento regional, desde a década de 1950.

De acordo com a Teoria dos Pólos, as diferenças entre as regiões diminuiriam com o avanço do desenvolvimento. Uma vez que uma região (pólo) crescesse economicamente, como conseqüência da ação da indústria motriz ou conjunto formado por várias unidades econômicas motrizes desse pólo, o crescimento se expandiria, beneficiando as regiões que a cercam. A natureza mecanicista presente nas propostas de planejamento ou organização regional resultantes da aplicação da Teoria dos Pólos de Desenvolvimento é uma importante crítica a essa teoria e pode ser

\footnotetext{
${ }^{35}$ BOS, H.C. Spatial dispersion of economic activity. s.l: s.ed. , 1965.

${ }^{36}$ São as teorias fundamentais da localização das atividades econômicas para análise da organização espacial e "estruturam-se, essencialmente, na interpretação das decisões empresariais, em uma economia de mercado, sobre o melhor sítio onde localizar-se" (Ferreira, 1989b, p.67). Pelas características, de acordo com Ferreira, eventualmente são denominadas de teorias neoclássicas da localização e, pela importância e origens histórico-doutrinárias, são teorias clássicas.
} 
verificada em Boisier (1989) e Souza (1988), citado por Hespanhol (1996). ${ }^{38}$ As teorias de crescimento e desenvolvimento possibilitaram não apenas estudos de desenvolvimento nos diferentes países e regiões como também permitiram o entendimento de relações entre os diferentes setores da economia e o crescimento desta.

Um dos instrumentos de análise regional e setorial bastante utilizados é a Matriz Insumo-Produto. A bibliografia sobre o assunto é bastante ampla e a descrição do método pode ser encontrada em Miller \& Blair (1985) e Shaffer (1999). Trata-se de uma metodologia que permite a identificação de setores "chaves" da economia. Os índices de Hirschman-Rasmussen são bastante utilizados nesse tipo de análise e são classificados como índices de Hirschman-Rasmussen para trás e para frente. O primeiro permite identificar o quanto um setor demanda de insumos dos outros setores da economia, e o segundo, o quanto o setor é demandado por outros. A análise de índices puros é um procedimento que auxilia na separação dos impactos de um determinado setor dos demais da economia, uma vez que considera o impacto puro da produção total de determinado setor. Além dessas informações, é possível calcularem-se multiplicadores de produção, de emprego e de renda cuja análise é similar à realizada por Keynes, conforme pode ser verificado em Shaffer (1999).

Outra forma de enfocar o desenvolvimento regional, cuja importância cresceu nos últimos anos, é a inclusão do aspecto de participação popular no processo. Pesquisadores internacionais vêm detectando a relação entre participação popular, organização de grupos sociais civis e desenvolvimento há algum tempo, através de estudos que se utilizam de outras variáveis além da renda para abordar o desenvolvimento de forma sócio-econômica. Para Kisil (s.d.) ${ }^{39}$, citado por Alves (1996):

“governância local para um desenvolvimento sustentável deverá ter sua performance avaliada de acordo com alguns aspectos importantes:

\footnotetext{
${ }^{37}$ PERROUX, F. Note sur la notion de pôle de croissance. In: Economie Appliquée. Paris: Presses Universitaires, 1955.

${ }^{38}$ SOUZA, M.A. Governo urbano. São Paulo: Nobel, 1988. (coleção Espaços)

${ }^{39}$ KISIL, M. Community-based projects: reflections on a strategy for sustainable development. s.n.t.
} 
a) ganhos econômicos através de aumentos da produção e/ou renda da comunidade; b) benefícios sociais em termos de educação, saúde, nutrição, suprimento de água e/ou outras facilidades públicas refletidas em indicadores sociais como mortalidade infantil, taxa de analfabetismo, etc.; c) efeitos de distribuição resultado de aumento na renda, ativos e/ou acesso a serviços pelos pobres; d) diminuição de discriminação em termos de sexo, raça, idade ou outras categorias atribuíveis, de modo a aumentar oportunidades sociais para grupos desavantajados onde existe discriminação; e, e) participação na tomada de decisões a nível local e/ou governamental" [Kisil (op.cit., p.7), citado por Alves (1996, p.34)].

Para Kisil, a partir da comunidade o desenvolvimento compatível com seus beneficiários se expandiria para o resto da nação através de políticas originadas das experiências locais. Especificamente sobre a América Latina, a descentralização de decisões do âmbito federal para o local obrigaria "cada comunidade a decidir a respeito de quais são os problemas, das possibilidades que existem, quais são as que os membros da comunidade têm recursos para lidar" [Kisil (op. cit., p.7), citado por Alves (1996, p.23)].

A visão expressa por autores que atribuem importância à participação popular no desenvolvimento está perfeitamente de acordo com as idéias defendidas por Sem (2000). Isso é particularmente verdadeiro ao se observar a importância que este autor atribui à condição de agente do indivíduo como membro do público e como participante de ações econômicas e sociais e políticas ${ }^{40}$. Para ele, a liberdade melhoraria o potencial das pessoas para cuidar de si mesmas e para influenciar o mundo, e, com as oportunidades adequadas nas economias e o processo de desenvolvimento orientado para o agente, o indivíduo deixaria de ser visto como beneficiário passivo de

${ }^{40}$ Agente em sua concepção "mais grandiosa", ou seja "alguém que age e ocasiona mudança e cujas realizações podem ser julgadas de acordo com seus próprios valores e objetivos, independentemente de as avaliarmos ou não também segundo algum critério externo" (Sen, 2000, p.33). Para Sen, a condição de agente livre e sustentável dos indivíduos é o "motor fundamental do desenvolvimento" (Sen, 2000, p.19). 
“engenhosos programas de desenvolvimento". Sen vai além de reconhecer que liberdades e direitos contribuem muito para progresso econômico: considera essa relação apenas adicional ao papel constitutivo desempenhado pelas liberdades (entre outras, de participação política).

O avanço teórico obtido com a inclusão da participação popular e outros aspectos sociais entre as variáveis explicativas possibilita o "remapeamento" de regiões e sub-regiões quanto ao potencial de desenvolvimento. Nesse sentido, é fundamental a compreensão do importante trabalho de Putnam (1993) sobre as diferenças existentes nas regiões da Itália e a relação entre tais diferenças e os níveis de desenvolvimento obtidos. O objetivo do estudo era contribuir para o entendimento do desempenho das instituições democráticas, mas a verdade é que Putnam foi bem mais além ao fornecer o instrumental necessário para a aplicação do conceito de capital social. Nas palavras do autor e seus colaboradores, o método teórico desenvolvido,

“projetado sobre a lógica da ação coletiva e o conceito de 'capital social', pretende não apenas explicar o caso da Itália, mas unir perspetivas históricas e de escolha racional de modo a poder entender melhor o desempenho institucional e a vida pública em muitos outros casos" (Putnam, 1993, p.16).

A partir da diversidade encontrada na Itália dos anos de 1970, o estudo de Putnam pôde comparar os resultados da reforma institucional ocorrida em 1970 ao longo de duas décadas.

"As fronteiras dos novos governos correspondem amplamente a territórios de regiões históricas da península. Desde a unificação (1870), entretanto, a estrutura administrativa da Itália foi altamente centralizada (modelada pela França Napoleônica). A autoridade local reportando-se diretamente à Roma (...). Nos anos 70, um período tumultuoso de reforma quebrou com o modelo de séculos centralizado 
de governo da Itália e delegou poderes e recursos sem precedentes para novos governos regionais" (Putnam, 1993, p.5 e p.15).

A partir de 1970, o autor acompanhou de perto a evolução de instituições regionais nascentes. Nas repetidas visitas a várias capitais regionais, logo percebeu diferenças dramáticas no desempenho institucional e para explicá-las, retomou o conceito de capital social encontrado em Coleman (1990):

\begin{abstract}
"Capital social é definido pelas suas funções. Não é uma única entidade, mas uma variedade diferente de entidades com duas características em comum: todas consistem de algum aspecto da estrutura social, e facilitam certas ações dos indivíduos que estão inseridos na estrutura. Como outras formas de capital, capital social é produtivo, tornando possível atingir certas finalidades que não seriam atingíveis na sua ausência. Assim como capital físico e humano, capital social não é totalmente fungível" (Coleman, 1990, p 302).
\end{abstract}

A intenção de Putnam e seus colaboradores era teórica, e o método utilizado foi empírico. Partindo-se dos pontos sobre os quais os novos institucionalistas concordam, buscaram evidências empíricas sobre esses. Tais pontos seriam o fato de as instituições moldarem a política e serem moldadas pela história. Tomaram, primeiramente, as instituições como variáveis independentes e analisaram como mudanças nessas variáveis afetam a identidade, o poder e as estratégias dos agentes políticos. Em seguida, tomaram as instituições como variáveis dependentes e examinaram como foram condicionadas pela história. Para Putnam, entre estes dois pontos, há um terceiro que teria sido negligenciado em trabalhos recentes sobre instituições. Adicionaram esse ponto ao admitir que o desempenho prático das instituições seria moldado pelo contexto social no qual operam.

A equipe de Putnam buscou reunir evidências sistemáticas ao longo do tempo e espaço para permitir análise longitudinal e cross-section. Para isso, conduziu um número de estudos separados que começaram com um foco sobre 6 regiões ao longo 
da península Itálica. Examinou mudanças através do tempo e fez comparações através do espaço. "A lógica da pesquisa requer comparações simultâneas de 15 ou 20 regiões ao longo de dimensões múltiplas e técnicas de regressão e análise fatorial simplificam drasticamente esta tarefa" (Putnam, 1993, p.12). Os aspectos avaliados discutidos são a estabilidade e a eficiência dos governos das várias regiões, o grau de inovações de suas leis, a eficiência ao implementar políticas voltadas, por exemplo, para a saúde, a habitação, a agricultura e o desenvolvimento industrial, a rapidez na satisfação das expectativas de seus cidadãos e quais instituições tiveram sucesso e quais não. Explicou essas diferenças em desempenho institucional, explorou as conexões entre modernidade econômica e desempenho institucional e examinou a ligação entre desempenho e o caráter da vida cívica - que denominaram civic community. Uma comunidade cívica, na definição de Tocqueville ${ }^{41}$, citada por Putnam (1993), é marcada por uma ativa cidadania com espírito público, pela igualdade nas relações políticas, por uma estrutura social de confiança e cooperação. Algumas regiões da Itália, detectou Putnam, são repletas de vibrantes redes de trabalho e comprometimento cívico, enquanto outras são atormentadas com políticas verticalmente estruturadas, uma vida social de fragmentação e isolamento e uma cultura da desconfiança. Essas diferenças na vida cívica desempenham um papel chave na explicação de sucesso institucional.

A forte ligação entre desempenho institucional e comunidade cívica levou Putnam (1993) a procurar as razões pelas quais algumas regiões apresentaram maiores graus de civismo que outras. As diferenças entre os regimes que vigoraram na Itália em períodos de aproximadamente um milênio atrás foram a resposta encontrada. No sul, existia uma monarquia poderosa, enquanto no centro e no norte um notável conjunto de repúblicas comunais. Dessa época medieval até a unificação da Itália no século dezenove, encontraram-se diferenças regionais sistemáticas em padrões de envolvimento cívico e solidariedade social. Conhecidas essas diferenças, a etapa seguinte consistiu em explorar as razões das normas e redes de entrosamento cívico que, tão poderosamente, afetaram a perspectiva de eficácia de um governo e explicar por que tradições cívicas

${ }^{41}$ TOCQUEVILLE, A. Democracy in America. Trad. de George Lawrence. S.1.: J.P. Mayer; Garden 
são tão estáveis ao longo de períodos. As conclusões refletem, segundo o autor, o poder de mudança institucional para remodelar a vida pública e as restrições poderosas que a história e o contexto social impõem sobre o sucesso institucional.

Ao levar em conta os novos limites regionais estabelecidos por diferenças quanto ao potencial de desenvolvimento, a teoria enfocada por Putnam forneceu um instrumental que vem ao encontro de necessidades de redefinição do papel do Estado e a necessidade de descentralização das decisões. Esse aspecto foi abordado por Boisier (1996), com ênfase na importância da descentralização para a elevação da competitividade das regiões. Essa constatação levou o autor a analisar o conceito de região e os novos cenários para o desenvolvimento regional. Kenichi Ohmae foi um dos autores revisados por Boisier. Na visão de Ohmae (1999), no contexto de globalização, o conceito de região está vinculado à cultura e não a território, e esse aspecto precisa ser melhor compreendido.

Para Ohmae (1999), os mais poderosos protagonistas nos assuntos mundiais serão os agrupamentos baseados na cultura, uma vez que os “Estados-nações”, em termos de fluxos reais de atividade econômica não têm mais "papéis como unidades significativas de participação na economia global do atual mundo sem fronteiras" (Ohmae, 1999, p.5). A insistência em manter formas tradicionais de soberania econômica sobre os povos e as regiões dentro de sua fronteira, ao invés de elevar o bemestar econômico, ressalta Ohmae, teve o efeito contrário. As linhas divisórias das fronteiras econômicas passaram a estar relacionadas aos fluxos de informação e não mais a linhas divisórias entre civilizações e Estados-nações. Quanto a esse aspecto, é importante mencionar que tanto Ohmae quanto Boisier (1996) deixam claro que as mudanças no conceito de região são conseqüências da evolução tecnológica, particularmente nos meios de comunicação. É esse contexto que tornou obsoleto antigos modelos de desenvolvimento regional e exige que a análise da questão regional seja realizada em outros "moldes". 


\subsubsection{Desenvolvimento regional}

O desconhecimento das particularidades regionais é provavelmente uma das causas de alguns fracassos de planejamentos. Para explicar o enfraquecimento do planejamento regional em toda a América Latina, merecem ser mencionados alguns dos fatores apresentados por Boisier (1989). Primeiramente, o emprego da teoria dos pólos com "descuido evidente das condições particulares das regiões onde foram inseridos" os pólos (Boisier, 1989, p.627). Os fracassos teriam ocorrido em freqüência muito maior quando esse instrumento foi utilizado em regiões com escassa base industrial. A prática tradicional do planejamento regional levou à separação artificial entre o sujeito e o objeto de planejamento, desconsiderando que as regiões "são expressões territoriais de grupos sociais, com história, consciência e expressão política, ou seja, são sujeitos e não objeto de planejamento" (Boisier, 1989, p.594). Segue afirmando que essa teoria gerou propostas de desenvolvimento regional inviáveis devido à ausência de participação das próprias comunidades regionais. Infelizmente, pela baixa participação das comunidades locais, esses equívocos podem continuar a ocorrer inclusive na região das bacias dos rios Tietê e Paraná, particularmente no que se refere a possibilidades associadas ao aproveitamento da hidrovia.

Dentre as particularidades regionais, destacam-se os estoques de capitais em suas cinco formas: físico, financeiro, natural, humano e social. Particularmente para a América Latina e os outros países do terceiro mundo, Rubens Utria, no prólogo de Baptista (1976) ${ }^{42}$, citado por Alves (1996, p.39) lembra que experiências desses países “deixaram a lição de que o capital financeiro e a tecnologia são condições necessárias, porém não suficientes, para a aceleração e planificação do desenvolvimento: o capital humano é imprescindível". Dessa época para cá, com a expansão do número desses estoques de quatro para cinco, as razões para o relativo atraso de algumas regiões foram bastante esclarecidas. A existência de estoques de capital social possibilita que se

${ }^{42}$ BAPTISTA, M.V. Desenvolvimento de comunidade: o estudo da integração do planejamento do desenvolvimento de comunidade no planejamento do desenvolvimento global. São Paulo: Cortez e Moraes, 1976. 170p. 
alcancem níveis de desenvolvimento superiores com menores estoques de capital financeiro. Esse é um aspecto altamente relevante para países em desenvolvimento, justamente pela escassez de capital financeiro.

\subsection{O desenvolvimento regional no Brasil}

No Brasil, a questão do desenvolvimento foi, durante um longo período, atrelada à participação do Estado na economia. Essa visão do papel do Estado no desenvolvimento, que predominou na América Latina durante muitos anos, foi, provavelmente, muito influenciada pelas idéias da CEPAL (Comissão Econômica das Nações Unidas para a América Latina). Na América Latina,

"a CEPAL teve um papel chave na teorização e elaboração de um corpo de idéias e políticas sobre o processo de industrialização nos países da região ao final da década de 40 (...). Para os cepalinos, o problema central reside no alcance da industrialização e, por esta via, do desenvolvimento" (Reyes, 1996, p.41-42).

De acordo com o autor, o modelo teórico da CEPAL teria sido influenciado por idéias de Keynes e seus sucessores. A visão de subdesenvolvimento da CEPAL, ainda de acordo com Reyes (1996), seria de carências estruturais que precisariam ser removidas, e o Estado teria um papel importante a cumprir nesse sentido. Os princípios básicos do modelo cepalino, mencionados pelo autor ao estudar o caso da Argentina, seriam:

“a) o princípio da demanda efetiva como determinante do nível de renda e emprego; b) a importância dada ao investimento como componente autônomo e dinâmico da procura global; c) a necessidade de intervenção estatal coordenada para influenciar sobre os componentes da oferta e da demanda global; d) a conveniência de uma distribuição progressiva da renda como meio de estimular a procura e aumentar o nível de renda e emprego; e) o desenvolvimento com base 
no mercado interno; f) a recomendação do uso do planejamento para superar deficiências estruturais; g) a recomendação da integração econômica aplicada não só ao espaço internacional mas ao interno de cada país; h) o uso das teorias de desenvolvimento com base em pólos (Perroux) e do desenvolvimento desequilibrado (Hirschman), recomendado para a promoção de setores e regiões atrasados" (Reyes, 1996, p.42).

O papel do Estado no desenvolvimento não foi entendido, por sucessivos governos autoritários brasileiros, como um mero catalisador do processo ou fornecedor de meios para o desenvolvimento. No governo de Juscelino Kubitschek (1955-1960), embora não se enquadre nos governos autoritários, a construção de Brasília talvez seja o exemplo que fale por si só. Cabe lembrar que o slogan da campanha presidencial, de acordo com Müller (1995), foi "Energia e Transporte". Nesses setores, Juscelino, de certa forma, dava continuidade a um processo iniciado no governo Vargas, reconhecidamente ditatorial. Sabe-se que o impulso inicial do setor energético brasileiro foi dado por capital e tecnologia estrangeiros, mas, a partir do governo nacionalista e intervencionista de Getúlio Vargas, o quadro foi bastante modificado, conforme Müller (1995). Em 1931, “a União assumiu o poder concedente de direitos de uso de qualquer curso ou queda d'água. O ponto culminante dessas medidas ocorreu em 1934, com a assinatura do Código de Águas" (Müller, 1995, p.10). A crise energética agravou-se e se agravaria mais ainda com a Segunda Grande Guerra. Já em meio à crise energética, a nova Constituição, após o golpe de 1937, passou a proibir "explicitamente qualquer novo projeto hidrelétrico por empresas estrangeiras. Foi quando se intensificou a participação dos governos federal e estadual como acionistas das empresas geradoras e distribuidoras" (Müller, 1995, p. 11). Em 1951, o País precisou assinar um empréstimo internacional e enfrentou pressões externas contra a postura nacionalista. O que se nota nesse período é que questões importantes ao desenvolvimento passaram a ser vistas como áreas de segurança nacional, e o Estado, mesmo recorrendo constantemente a empréstimos no exterior, passou a atuar fortemente no setor produtivo. Essa tendência, 
que se extrapolou para outros setores da economia, seria mantida no País por muitos anos, mantendo-se nos sucessivos governos militares até as crises econômicas dos anos de 1980.

A tendência de forte atuação do Estado na economia refletiu-se na sua atuação nas políticas de desenvolvimento regional. Tais políticas estão resumidas em Pereira (1996). Para a implantação dessas, o governo federal não apenas criou organismos de fomento, como as superintendências de desenvolvimento e mecanismos regionais de incentivos (por exemplo a Zona Franca de Manaus), como também criou bancos para administrar os programas de desenvolvimento regional. É o caso do Banco do Nordeste do Brasil, de 1952, o Banco de Crédito da Borracha (reestruturado em 1957, passou a ser Banco de Crédito da Amazônia - BCA, depois BASA) e dos diversos Bancos de Desenvolvimento. Quanto às Superintendências, cabe lembrar que a SUDENE (para o Nordeste) foi criada a partir do Grupo de Trabalho para o Desenvolvimento do Nordeste, em 1959. Seguiu-se a criação da SUDAM (para a Amazônia), nos moldes da SUDENE e, também na Amazônia, a SUFRAMA (Superintendência da Zona Franca de Manaus). A partir de então, a lista de organismos para incentivar as regiões ${ }^{43}$ se estenderia.

A visão dos formuladores de política brasileiros parece ter sido fortemente influenciada pela teoria dos pólos de desenvolvimento. Pereira (1996) menciona a influência da teoria dos pólos nas políticas de desenvolvimento regional e exemplifica sua aplicação no Brasil. Andrade $(1970)^{44}$, citado por Hespanhol (1996), salienta a grande popularidade alcançada por essa teoria nos anos cinqüenta. A teoria dos pólos motivou, na época, a realização de estudos, visando à identificação dos chamados centros ou pólos de desenvolvimento no território brasileiro. Ao longo das décadas de 1950, e, sobretudo 1960, cientistas sociais de várias especialidades realizaram inúmeros estudos com objetivo de identificar os chamados "pólos" de desenvolvimento em vários

\footnotetext{
${ }^{43}$ SUDESUL, SUDECO, SUVALE, etc.

${ }^{44}$ ANDRADE, M.C. de. Espaço, polarização e desenvolvimento: a teoria dos pólos de desenvolvimento e a realidade nordestina. São Paulo: Braziliense, 1970.
} 
estados da federação. Dos estudos "realizados, sobretudo nas zonas de atuação da CIBPU e da SUDENE, foram selecionados um ou dois pólos de desenvolvimento nos territórios nacionais" (Hespanhol, 1996, p.28).

A associação entre o planejamento regional e as bacias hidrográficas é mencionada por Boisier (1989) e por Hespanhol (1996). O primeiro afirma que o desenvolvimento regional na América Latina foi inicialmente entendido como a racionalização e exploração das bacias hidrográficas desde a década de 1940 sob influência da Tenessee Valley Authority (TVA), no Estados Unidos. O segundo reportase ao trabalho de Souza (op. cit.), que associa o surgimento do planejamento regional no Brasil com o planejamento das bacias hidrográficas. Os destaques apresentados foram a Paraná-Uruguai, feito na década de 1950 e o planejamento da região Nordeste, com a criação da SUDENE.

A discussão sobre as bacias hidrográficas leva, inevitavelmente, à relação entre o potencial de desenvolvimento regional através de construção de hidrelétricas e os problemas que geram as regiões onde são instaladas. Müller (1995) discute o assunto e aponta alguns conflitos locais derivados da construção dessas usinas.

"A reorganização dos espaços, a reestruturação dos sistemas
produtivos e a recuperação da infra-estrutura acontecem
simultaneamente com a formação do reservatório, reagindo
naturalmente à desestruturação imposta. Este fenômeno de
reacomodação produz uma oportunidade ímpar (e rara) para se
redirecionar a estrutura socioeconômica de uma considerável região.
Nessa ocasião, pode-se implantar as bases de um modelo ideal de
desenvolvimento, beneficiando-se das novas opções oferecidas pelo
reservatório. Nessa hora, o reservatório deve ser visto como uma
hidrovia, fonte de proteínas e de suprimento de água, ainda que em
potencial” (Müller, 1995, p. 278).


Os conflitos derivados de construção de hidrelétricas, de acordo com Müller (1995), distribuem-se entre vários segmentos sociais. Esses segmentos formam o que se chama de "caldeirão de interesses" e foram enumerados da seguinte forma: proprietários rurais e sua estrutura de produção primária; industriais (quando instalados no local do empreendimento, ou disposição geográfica mais distante, mas supridos pela matériaprima ali existente); serviços e comércio (tanto os diretamente atingidos como os que atendiam à população atingida), poderes públicos responsáveis pela infra-estrutura rural e urbana e por outros serviços comunitários; e órgãos não governamentais (cooperativas, clubes, associações e outros, que terão que transferir-se ou extinguir-se). Ao discutir o aspecto de desenvolvimento sustentável, Müller considerou que a implantação dessas usinas tem,

"lamentavelmente, registros de experiências onde sociedades viram suas bases de sustentação econômica e seus valores socioculturais repentinamente solapados. Ainda que a geração hidrelétrica seja sustentável, algumas regiões atingidas para que ela fosse gerada tiveram, em lugar de desenvolvimento, retrocesso insustentável" (Müller, 1995, p.45).

Em mais de uma oportunidade, o Estado brasileiro tomou para si a função de promover o desenvolvimento regional, mas com as mudanças de ordem econômica e política no Brasil, na década de 1980, a visão de planejamento regional também se modificou. Para Haddad (1989), as questões de desequilíbrio espaciais no processo de crescimento econômico passaram a ser tratadas "de forma assistencialista em termos de sua concepção, de forma casuística em termos de sua programação, e de forma clientelista em termos de sua articulação política" (Haddad, 1989, p.19). A síntese das alterações ocorridas no período, apresentadas pelo autor, auxilia no entendimento quanto ao afastamento do Estado das chamadas questões regionais.

"Como é conhecido, ao longo da década passada, era comum os três níveis de Governo (Federal, Estaduais e Municipais) disporem de 
recursos financeiros da ordem de dez a quinze bilhões de dólares de poupança anual em seus orçamentos fiscais para financiar investimentos de infra-estrutura da economia brasileira em diversas regiões. Esta poupança, concentrada principalmente nos orçamentos do Governo Federal e de alguns Governos Estaduais e Municipais das áreas desenvolvidas do País, dava ao processo de planejamento regional um significativo grau de liberdade para a definição de programas e de projetos a serem financiados e implementados (...). Infelizmente, essa fonte de financiamento dos gastos de investimento declinou sensivelmente na atual década, a ponto de se estimar que poderia ser nula ou negativa a poupança em conta corrente do Governo em 1988, se não fossem tomadas medidas de natureza estabilizadora" (Haddad, 1989, p.22).

Ao final dos anos de 1980, não havia meios para o financiamento de investimentos públicos com recursos nacionais. Haddad citou a diminuição da arrecadação em termos de percentagem do PIB, a elevação dos subsídios e a elevação dos encargos da dívida pública como os principais fatores para a diminuição dos investimentos públicos. A situação das empresas estatais controladas pelo Governo Federal destinadas a financiar programas e projetos nas regiões menos desenvolvidas agravava o quadro.

"Registra-se que, em meados da década de setenta, essas empresas (estatais) chegaram a gerar uma poupança equivalente a $20 \%$ do total do setor privado, a qual financiava quase dois terços dos seus investimentos, muitos dos quais realizados naquelas regiões, tendo em vista critérios de rentabilidade social dos projetos de desenvolvimento. Atualmente, a geração da poupança própria corrente das empresas estatais está conseguindo financiar bem menos da metade de seus investimentos, mesmo porque estes têm sido drasticamente reduzidos para se acomodar a esta disponibilidade de poupança (...). Assim, é 
reduzida a flexibilidade que estas empresas dispõem para alocar recursos escassos em programas e projetos de desenvolvimento regional; como o Governo Federal e os Governos Estaduais não têm condições de promover transferências significativas dos orçamentos fiscais para os programas de investimentos dessas empresas (como no passado), a sua intervenção direta nas economias periféricas através delas tende a ser mais e mais restrita" (Haddad, 1989, p.23).

As mudanças verificadas no período refletiram-se na Constituição de 1988. De acordo com Lavinas \& Magina (1995), planejamento regional é citado formalmente nos artigos 21 (IX), 48 (IX), 58 (VI), 165 (par.1 e 4), 166 (par.1), 174 e 218. Além de apresentarem o conteúdo dos principais artigos que tratam da questão, os autores indicam as emendas que surgiram até então. Essas emendas reforçam o caráter descentralizador da Carta Magna ao fortalecer o "poder de decisão dos Estados na elaboração e execução, em parceria com a União, dos planos de desenvolvimento regional" (Lavinas \& Magina, 1995, p.7). Os autores levantaram os artigos e dispositivos do texto vigente em 1995, relacionados à questão das desigualdades regionais e ao federalismo, particularmente as relações financeiras e administrativas entre entes federados. Através de busca junto ao Prodasen (Sistema de Informações do Senado), identificaram as mudanças propostas ${ }^{45}$ e respectivas justificativas. Dividiram a análise em competências do planejamento regional, instrumentos, descentralização das competências administrativas e a reforma fiscal e descentralização financeira. Os maiores destaques quanto ao planejamento regional são os artigos 165 e 174 . O primeiro, que trata dos planos plurianuais, indica que o planejamento nacional seria realizado "sob uma ótica regionalizada", e o artigo 174 delimita as funções do Estado como agente normativo e regulador da atividade econômica.

No texto constitucional, de acordo com Lavinas \& Magina (1995), multiplicaram-se as referências à obrigatoriedade de se regionalizar várias atividades e

\footnotetext{
${ }^{45}$ Os autores examinaram as principais propostas e a origem regional através de 510 emendas revisoras encaminhadas para a reforma constitucional em matéria de desenvolvimento regional.
} 
atribuições federativas, entre elas o planejamento, os planos, a ordenação do território, os programas plurianuais, o orçamento, etc. “A redefinição dos critérios de partilha e rateio dos recursos tributários em favor de maior participação dos estados e municípios é um dos traços marcantes da Constituição de 1988 e representa um avanço na consolidação de uma nova engenharia federativa pautada em critérios de eqüidade vertical entre as esferas administrativas" (Lavinas \& Magina, 1995, p.16). Para os autores, a descentralização financeira não foi acompanhada de redistribuição das competências e a União estaria sobrecarregada (atribuições incompatíveis com os recursos financeiros).

O cumprimento de algumas determinações constitucionais seria, ainda conforme Lavinas \& Magina (1995), extremamente complicado, como, por exemplo, as de regionalizar os investimentos plurianuais, a ordenação do território, os planos, etc. Tal regionalização não teria contemplado igualmente todas as macrorregiões brasileiras, sendo o sudeste sub-representado na redistribuição dos recursos públicos. Lembrando que entes federados são estados e municípios, discordam da nomeação de regiões específicas na Constituição "tal como o foram no caso dos fundos constitucionais, dos programas de irrigação, etc.” (Lavinas e Magina, 1995, p.2).

Apesar das mudanças no trato da questão regional, há autores que ainda insistem no fortalecimento do Estado para propiciar o desenvolvimento às regiões mais atrasadas. Cano (1994) observa que a constituição sustentou o sistema de incentivos fiscais por mais alguns anos e obrigou a regionalização de parte do orçamento público e das estatais. A proposta do autor é a volta do "Estado com o seu poder de planejar o desenvolvimento econômico" (Cano, 1994, p. 313), com destaque para a implantação de políticas sociais, "notadamente de reforma agrária". Para as regiões, restariam "um esforço de planejamento industrial e agro-industrial, uma tentativa de regionalizar esforços de investimentos, alguma disseminação de infra-estrutura econômica pelas regiões e políticas sociais, estas disseminadas em todo o território nacional" (Cano, 1994, p.320). 
O que deve ser ressaltado é que, apesar dos esforços de descentralização consolidados na Constituição, há ainda uma busca por formas de atuação governamental no desenvolvimento regional. Esse aspecto está refletido no número de emendas apresentadas sobre o tema, que totalizavam 510 até o ano de 1995 (data da análise de Lavinas e Magina) e no descontentamento expresso no artigo de Cano. A postura de Cano é evidentemente a favor de um estado centralizador. Cabe lembrar que isso contraria os resultados obtidos por Putnam (1993). No trabalho sobre a Itália, mesmo nas regiões que não acompanharam o desenvolvimento alcançado pelas cidades do norte, as manifestações, após duas décadas, eram de apoio às medidas de descentralização.

A importância da participação popular no desenvolvimento não recebeu ainda a devida atenção nas pesquisas realizadas no País, mas é possível detectar-se, em alguns autores já mencionados, uma preocupação nesse sentido. Nota-se certa insatisfação quanto à forma como se abordou a questão do desenvolvimento regional "de cima para baixo" e sugestões para a adoção de outro paradigma de desenvolvimento cujas concepção e bases operacionais "estão intimamente relacionadas com as condições sócio-culturais, históricas e institucionais específicas de cada região" (Haddad, 1989, p.32). O descontentamento observado não foi apenas com a atuação pública de desenvolvimento regional, mas também com o instrumental utilizado. Essa insatisfação está claramente demonstrada em Boisier (1989), para o qual, sobre o planejamento na América Latina, há necessidade de se "reconhecer que se atuou equivocadamente, do ponto de vista técnico, e se atuou também com soberba, tratando-se de impor determinados conceitos e ações sobre espaços que não eram somente físicos, porém sociais" (Boisier, 1989, p.594). Além de chamar a atenção para a necessidade de um novo paradigma, o texto de Boisier demonstra estar em sintonia com idéias que posteriormente foram tratadas por de Sen (2000), particularmente com o conceito de agente já discutido. Pode-se verificar essa sintonia em alguns trechos:

"Romper com a separação artificial entre sujeito e objeto (...) implica a passagem da região-objeto para a região-sujeito, o reconhecimento das regiões como atores no processo de planejamento (...). Isso só é 
possível quando o espaço geográfico for espaço social. Ou seja, uma matriz de grupos sociais cujo nexo de articulação seja dado pela consciência coletiva de pertencer a um território comum (...).

Quando for reconhecida a função de sujeito ou de ator das regiões, e isso não poderá ser resultado de leis ou decretos, senão da própria realidade, aquele reconhecimento terá implicações práticas, concretas e claras. Com efeito, o fato de ser ator no processo de planejamento, mesmo que seja considerado como um direito de todo sujeito potencial de planejamento não deixa de estar certo que, como todo direito, fazêlo efetivo pressupõe um ato de vontade. Em outras palavras, o direito é estabelecido, mas o exercício do direito se conquista. No caso regional, é a comunidade regional quem deve exercer o direito de ser um ator (...). As propostas de desenvolvimento regional deverão ter dimensões sociais e políticas e firmarão suas raízes em demandas, não só de caráter econômico, senão que se nutrirão e, às vezes, estarão associadas a etnias, a culturas, em resumo, a movimentos sociais regionais muito diversificados" (Boisier, 1989, p.595-596).

Embora a importância da participação popular no desenvolvimento regional tenha sido reconhecida por pesquisadores brasileiros, o conceito de capital social ainda não faz parte das pesquisas realizadas. Knack e Keefer (1997) apresentaram valores bastante baixos para essa forma de capital no Brasil, dentre os vinte e nove países que analisaram. As variáveis analisadas foram confiança, civismo e participação em grupos. Para o indicador de confiança, o Brasil ficou em último lugar na classificação. Os valores atribuídos a essa variável foram obtidos através de perguntas sobre a opinião das pessoas em relação à confiança nas outras. Nota-se que se trata de uma estimativa para o País como um todo, que não permite o entendimento das diferentes regiões do Brasil quanto a esse recurso. Sendo o Brasil um país de enormes desigualdades regionais, é de se esperar que também quanto ao estoque de capital social não apresente uniformidade. 
É importante que não se perca de vista o contexto em que o Brasil buscou seu desenvolvimento, no que diz respeito aos estoques de capitais para realizá-lo. Para os países menos desenvolvidos, a escassez do capital financeiro é, sem dúvida, um importante fator limitante ao desenvolvimento. O Brasil não é exceção, dada a baixa taxa de poupança interna e dificuldades para atrair o capital internacional enfrentadas em alguns períodos de sua história econômica. Com o esgotamento do modelo de transferência de recursos da agricultura para a indústria, como outros países menos desenvolvidos, o Brasil captou recursos financeiros para realizar seus investimentos em capital físico. O trecho a seguir resume os problemas relacionados à captação de recursos financeiros enfrentados pelo País em sua história recente:

"Atingido duas vezes na década de 70 pelas altas consecutivas do preço do petróleo - em 1973 e em 1979 - o País emergiu mais frágil para enfrentar os desafios à sua frente nos anos 80 . Endividado e com uma série de programas de investimentos inacabados, o Brasil viu-se mergulhado na crise da dívida de 1982, quando o México subitamente suspendeu os pagamentos do seu serviço (...). O Brasil, por seu turno, oscilou entre cumprir e não cumprir compromissos. Fez uma moratória declarada em 1987 e outra não declarada em 1989" (Carta do IBRE, 1989, p.9).

As sucessivas moratórias produziram recessão. A dívida brasileira não foi reduzida, "em grande medida, porque o Governo absorveu o problema para si, tomando os empréstimos para o seu próprio financiamento" (Carta do IBRE, 1989, p.9). É preciso que se estenda a discussão sobre a captação de recursos financeiros pelo Brasil nesse período conturbado do mercado financeiro, a fim de se compreender melhor as razões para a interrupção, na década de 1980, do crescimento econômico e as dificuldades para retomá-lo desde então.

A captação de recursos financeiros, no mercado internacional, para o desenvolvimento foi inviabilizada, nos anos oitenta, pela condição altamente 
desfavorável do mercado internacional aos países devedores. Peres \& Rask (1990) discutem as dificuldades enfrentadas pelos países devedores para o cumprimento da agenda de pagamentos a credores internacionais, atribuindo essas dificuldades principalmente ao crescimento das taxas de inflação americana e às políticas fiscais e monetárias que visavam a seu controle. Altas taxas de inflação e elevação das taxas de juros pelos Estados Unidos teriam sido, segundo os autores, a causa inicial crucial que dificultou o pagamento das dívidas por países devedores (inclusive o Brasil), levando-os a reduzirem as taxas de crescimento. Mesmo o Plano Baker teria feito pouco para ajudar esses países a promover desenvolvimento econômico. Alguns dados fornecidos pelos autores não deixam dúvidas sobre as dificuldades enfrentadas por países menos desenvolvidos para captar recursos: as taxas de juros reais que chegaram a ser negativas em 1974 e 1975 atingiram um novo patamar a partir de 1981, quando partiram de valores inferiores a $2 \%$ e mantiveram-se entre 6 e $8 \%$. Os valores das taxas de juros reais explicam em grande parte a captação de recursos na década de 1970 e as dificuldades de pagamento nos anos que se seguiram. É possível um paralelo entre esses valores e os volumosos investimentos em capital físico realizados no Brasil, o crescimento obtido no período de crédito farto e barato bem como as dificuldades nos anos da "década perdida".

Com o choque do petróleo, a alta dos juros no mercado internacional geraria, por si só, dificuldades aos países devedores, inclusive ao Brasil. A situação brasileira, entretanto, seria agravada pela insistência ao estímulo ao crescimento, evitando redução da demanda agregada. O País aproveitou-se, corretamente, dos juros baixos no período anterior ao captar recursos externos para financiar o crescimento verificado nos anos da década de 1970, mas a insistência em continuar a crescer apesar das mudanças nos preços do petróleo gerou imensas dificuldades para equilibrar suas contas externas. As tentativas de se restabelecer o equilíbrio ofuscaram, durante alguns anos, a necessidade de se retomar o desenvolvimento econômico. A predominância das questões urgentes pode ser ilustrada com análises do período encontradas na literatura. 
Foram várias as tentativas de estabilizar a economia brasileira na década de 1980, marcados principalmente pelas altas taxas de inflação e desequilíbrios nas contas externas. O artigo de Oliveira (1999), ao discutir as relações do Brasil com o Fundo Monetário Internacional (FMI), explica este tumultuado período da história econômica brasileira. Taxa de câmbio congelada e metas não realistas para sua desvalorização estimulavam as importações e a demanda por ativos em moeda estrangeira, gerando sérios desequilíbrios. Conforme já mencionado, o País viu-se obrigado a recorrer ao FMI após a moratória do México em 1982. Ao não cumprir o programa com o FMI, o Brasil tornou-se, em 1983, de acordo com o autor, o principal objeto de preocupação do mercado internacional. Essa situação foi amenizada pela melhora na balança comercial gerada pelos impactos positivos da recuperação da economia americana. Mesmo assim, o país prosseguiu com dificuldades em cumprir as metas do FMI e recorreu ao Fundo Monetário mais uma vez como uma "resposta emergencial a uma crise de liquidez em vez de um compromisso de longo prazo com o ajustamento" (Oliveira, 1999, p.9). Com o fracasso do Plano Cruzado, o governo optou por uma moratória temporária.

O mercado internacional de crédito voluntário reabriu-se através de aplicação em bolsas, colocação de bônus e commercial papers no Governo Collor, e houve alguma recuperação do investimento direto. A estratégia de juros elevados atraiu volumoso ingresso de recursos externos, mas elevou a dívida pública, e a crise política agravou ainda mais o quadro econômico. O autor sintetiza em:

"Nos anos oitenta, o problema externo não era temporário. A interrupção dos empréstimos privados e as condições macroeconômicas mundiais instáveis levaram a uma série de falhas no mercado. O FMI e outras instituições foram importantes para sua superação" (Oliveira, 1999, p.13).

Afirma ainda que:

"O tamanho da dívida impõe ao país um serviço oneroso. Para evitar a moratória foi necessário rolar a dívida o que impôs uma sequiência de 
pacotes de empréstimos (...) tais empréstimos serviam ao propósito de defender o valor esperado das exigências dos credores brasileiros" (Oliveira, 1999, p.13).

Aos problemas relacionados às taxas de juros no mercado internacional, somou-se, na década de 1980, a fuga de capitais estrangeiros dos países em desenvolvimento, com raízes, provavelmente, nas dívidas externas e agravamento das condições econômicas e políticas desses países. Para o Banco Mundial, essas seriam as causas que levaram credores e investidores internacionais a evitarem tais países (Banco Mundial, 1991, p.140-142). Talvez pela urgência das questões sobre como equilibrar a balança, outra questão não menos importante tenha "escapado" e ressurgiu com a estabilidade econômica obtida com o Plano Real: como canalizar tais recursos para o desenvolvimento econômico e, mais especificamente, para minimizar desigualdades regionais.

O País realizou volumosos investimentos em capital físico, nos anos de baixas taxas de juros no mercado financeiro internacional. Dentre as obras iniciadas no período, destacam-se, no transporte as rodovias Transamazônica e Perimetral Norte e, na área energética, as usinas de Angra dos Reis e as hidrelétricas. Quanto a essas últimas, é interessante observar a evolução do País nesse setor. O destaque para o período é o início da construção de Itaipu (1976), cujo tratado, de mesmo nome, foi assinado entre Brasil e Paraguai em 1973. Mais de 66 barragens hidrelétricas foram construídas no período entre 1960 e 1980. A relevância desse período na construção de hidrelétricas é evidente quando esses números, apresentados por Müller (1995), são comparados com outros referentes ao período anterior e também mencionados pelo mesmo autor. Até 1950, existiam apenas 26 barragens no Brasil para a geração de energia elétrica. $\mathrm{Na}$ década de 1950, 21 barragens foram construídas com finalidade de geração de energia.

Apesar da relativa disponibilidade de capital financeiro no período de juros baixos no mercado internacional, não foi priorizado investimento em capital humano. Uma exceção aconteceu, na área agrícola, com a criação da Empresa Brasileira de 
Pesquisa Agropecuária (EMBRAPA) e com os investimentos realizados em pesquisa e treinamento de mão-de-obra altamente especializada. Por outro lado, os esforços direcionados a suprir a carência do país em capital humano foram insuficientes, principalmente quanto à erradicação do analfabetismo. ${ }^{46}$ Mudanças nas áreas de educação ocorridas em períodos mais recentes parecem ainda insuficientes para modificar o quadro de atraso no preparo da obra para o mercado altamente competitivo com que o País já se defronta. Barros et al. (1997), analisaram as perspectivas para o mercado de trabalho brasileiro até 2005 (nível salarial e taxa de desemprego para trabalho qualificado e não qualificado). Os resultados indicaram, para o cenário básico ${ }^{47}$, que a força de trabalho qualificada (ou seja, com educação secundária) seria insuficiente para satisfazer a demanda. Nas palavras dos autores, "o sistema educacional continuará a perder a corrida para o progresso tecnológico, expandindo-se muito mais lentamente em relação ao viés deste progresso" (Barros et al., 1997, p.26).

Com relação ao estoque de capital social no Brasil, é importante lembrar que, durante os anos de crescimento econômico, o País estava sob um regime político autoritário que não favorecia a formação de cidadãos no que diz respeito à participação na comunidade. A relação entre regimes totalitários e baixos estoques de capital social é mencionada por Peres (2000), com ênfase às dificuldades econômicas enfrentadas pela antiga União Soviética. Para o autor, tais dificuldades parecem um sinal bastante evidente da influência negativa de regimes totalitários sobre a formação e manutenção do estoque de capital social. Apesar de seus estoques provavelmente bastante satisfatórios de capital humano e capital natural e da possibilidade de atrair capital financeiro e mesmo físico do exterior, o desempenho das ex-repúblicas socialistas foi frustrante. $\mathrm{O}$ desestímulo à participação comunitária na solução dos problemas, conforme Peres, pode ajudar a esclarecer as razões para tal frustração. No Brasil, foi

\footnotetext{
${ }^{46}$ Como ilustração de um esforço em investimento em capital humano durante os anos de altas taxas de crescimento, cabe lembrar o extinto Movimento Brasileiro de Alfabetização (MOBRAL), voltado à alfabetização de adultos.

${ }^{47}$ Os cenários envolvem alternativas baseadas em estimativas de progresso tecnológico e crescimento econômico. O cenário básico apresenta crescimento alto, diferenciado (por setor primário, secundário e terciário) e progresso tecnológico médio.
} 
possível notar-se que a mudança do regime político no Brasil fez ressurgir timidamente o interesse por participação na resolução dos problemas comunitários ${ }^{48}$ e a organização dos grupos sociais, mas são poucos os trabalhos que consideram explicitamente esse aspecto. Dentre eles, o estudo de Alves (1996) para o município paulista de Vera Cruz, que será discutido a seguir.

\subsection{A questão do desenvolvimento no Estado de São Paulo}

Alves (1996) apresenta uma revisão dos trabalhos sobre o desenvolvimento do Estado de São Paulo. O processo do desenvolvimento do estado estaria, na análise dos autores revisados por Alves, relacionado à demografia e à evolução do valor agregado da produção. Assim, a "interiorização do desenvolvimento" é vista como associada ao deslocamento da indústria da capital para algumas cidades do interior.

“A evolução da industrialização mostra que o interior voltou a crescer em importância relativa. Até o início deste século, a economia paulista era baseada na agricultura e o interior do estado tinha uma grande importância relativa. Com a industrialização, a capital do estado passou a predominar economicamente, processo que sofreu uma tendência de inversão a partir do momento em que começou a haver a industrialização mais intensa do interior" (Alves, 1996, p.7).

De acordo com Negri et al. $(1988)^{49}$, citado por Alves, ao final da década de 1920, o interior detinha 29\% da produção industrial do Estado de São Paulo, e, dessa época até o período 1956/1961, houve um avanço da industrialização no interior. Inicialmente, esse avanço era para complementar a produção da grande São Paulo, e, a partir da década de 1970, implantou-se no interior indústrias de porte médio a grande,

${ }^{48}$ A iniciativa mais conhecida de âmbito nacional talvez seja o Programa Comunidade Solidária.

${ }^{49}$ NEGRI, B.; GONÇALVES, M.F.; CANO, W. O processo de interiorização e urbanização do Estado de São Paulo (1920-1980). In: Fundação Sistema Estadual de Análise de Dados. A interiorização do 
em segmentos de maior complexidade. Azzoni (1993) ${ }^{50}$ e Silva (1994) ${ }^{51}$, também citados por Alves (1996, p.8), confirmam esse processo. Para o primeiro, “internamente a São Paulo, já é conhecida a perda de importância relativa da Capital em primeiro momento, e da Região Metropolitana da Grande São Paulo, em segundo, no total da produção estadual" (Azzoni, 1993, p. 8). Alves também apresenta os dados de valor adicionado referentes ao período de 1970 a 1990, utilizados por Silva, cuja análise indica que

“apesar de ainda predominar uma elevada concentração produtiva na Grande São Paulo e na Região Administrativa de Campinas, já se verifica um processo de interiorização do desenvolvimento econômico.(...) enquanto a Região Metropolitana não acompanhou o crescimento total do Estado, outras regiões passaram a ser importantes no conjunto da economia paulista, seja pela expansão da indústria de ponta, agroindústria ou serviços" (Silva, 1994, p.11, citado por Alves, 1996, p.8).

Apesar da industrialização do interior paulista ser enfatizada por vários autores, é importante reconhecer as diferenças entre as regiões quanto à inserção no processo de industrialização. Hespanhol (1996) apresenta uma série de dados que explicam tais diferenças entre a região oeste do estado de São Paulo e áreas que se inseriram no processo de industrialização. Dentre essas diferenças, destaca-se a expressiva concentração fundiária e a não-modernização da base técnica da agricultura. Cabe insistir na necessidade de compreender melhor as razões para esse atraso. Elas precisam ser levadas em conta nos projetos a serem implantados, particularmente naqueles associados ao aproveitamento da hidrovia Tietê-Paraná. Além da

desenvolvimento econômico no Estado de São Paulo, 1920-1980. São Paulo: SEADE, 1988. p.1105. Coleção Economia Paulista, v.1, n.1

${ }^{50}$ AZZONI, C.R. Como está São Paulo? In: AZZONI, C.R. (Org.). Como está São Paulo: as pessoas/a produção/ os municípios/ o meio ambiente. São Paulo: Secretaria de Planejamento e Gestão, 1993. p.7-9. 
industrialização do interior do Estado de São Paulo, outro aspecto discutido nos trabalhos sobre o desenvolvimento paulista diz respeito ao crescimento da população. Tanto Hespanhol quanto Alves, tratam deste aspecto. O primeiro chama a atenção para a redução da população da região de Andradina entre os anos de 1970 e 1980, que foi de 13\%, e o baixo crescimento relativo entre 1980 e 1991 (apenas 10\% contra 24,5\% no Estado de São Paulo). Alves apoia-se no trabalho de Azzoni:

"A população tem crescido a taxas assimétricas no estado de São Paulo, indicando uma possível tendência de aumento de importância em determinadas regiões. Segundo Azzoni (1993), as regiões a Oeste do estado aumentaram as taxas de crescimento, as do Leste diminuíram e a região central manteve o crescimento populacional no período analisado - 1970 a 1991 (... ). As regiões Oeste Paulista e a área central não aumentaram sua participação relativa do Estado. (...) verifica-se que, apesar da tendência de crescimento, essas áreas não aumentaram sua participação relativa devido ao tamanho reduzido de suas populações, havendo contudo uma homogeneização das taxas de urbanização (percentual de população urbana no município - cidade, vilas e áreas urbanas - , em relação à população total.) entre as Regiões do Estado de São Paulo (...). Outro interessante aspecto é o fato de que o volume de população rural tem diminuído desde a década de 60 , passando de 4.827 mil pessoas em 1960 a 2.273 mil pessoas em 1991" (Azzoni, op. cit., citado por Alves, 1996, p.10, 12-13).

A literatura sobre desenvolvimento de São Paulo indica que, assim como provavelmente ocorreu em outros estados da Federação, o desenvolvimento nesse estado não foi uniforme. Hespanhol (1996), embora tivesse como prioridade a região de Andradina, no extremo oeste do Estado de São Paulo, procurou explicar por que vastas

${ }^{51}$ SILVA, V.M. Descentralização e caracterização do crescimento econômico no Estado de São Paulo entre 1970 e 1991. São Paulo: Fundação Prefeito Faria Lima - CEPAM, 1994. 43p. (Série Estudos e Pesquisas,4) 
porções do território paulista praticamente não modernizaram sua agricultura. Para tanto, incluiu discussões sobre todo o oeste paulista e algumas comparações com outros estados (Mato Grosso, Mato Grosso do Sul e Paraná). Ao contrário do que ocorreu em outras regiões do Estado de São Paulo, a região oeste não foi incorporada ao processo agro-industrial. Apresenta os dados das regiões administrativas de São José do Rio Preto, Araçatuba, Presidente Prudente e Marília, mostrando que, em conjunto, continuam perdendo importância relativa em termos de valor da transformação industrial no conjunto estadual. Antes de atingir o oeste paulista, a atividade industrial direcionouse aos estados vizinhos. Assim, para o autor, o não-engajamento da região no processo de industrialização se reflete na modernização da agricultura em função do nãoatrelamento das atividades agropecuárias à agroindústria.

Diferenças entre a região Oeste paulista e outras unidades da federação são mencionadas por Hespanhol (1996) quanto à interferência do estado. Por exemplo, áreas do Mato Grosso do Sul e Goiás modernizaram-se em função dos programas de desenvolvimento implementados pelo governo federal nos anos de 1970 (Polocentro e Programa de Corredores de Exportação). Também o Paraná beneficiou-se da atuação do governo federal em função do cultivo de trigo e soja que receberam altos incentivos através do crédito rural. A atuação dos governos estaduais também não foi uniforme. Paraná, Mato Grosso e Mato Grosso do Sul estimularam amplamente a modernização da agricultura, enquanto o governo paulista praticamente não atuou no processo. Os dados mencionados pelo autor para dar suporte a suas idéias foram obtidos de Martins (1991) e indicam que a participação da Secretaria da Agricultura variou, no orçamento do governo estadual, de 5 a 7\%, no período entre 1950 e 1968, quando, após reformulações, passou a representar apenas entre 1 e $2 \%$ ao longo dos anos 1970 e 1980 . Nas palavras do autor:

"No caso paulista, o governo estadual teve atuação pouco pronunciada no estímulo à modernização da agricultura, ou seja, diferentemente de outras áreas, o governo estadual não procurou organizar o setor para usufruir das vantagens oferecidas pelo governo federal até pelo menos 
o final da década de 1970, justamente no período em que os recursos federais eram mais abundantes.

As regiões do Estado de São Paulo cuja agricultura apresentava maior vinculação ao mercado onde a atuação das agroindústrias e/ou das cooperativas era mais expressiva, aproveitaram-se dos recursos oferecidos pelo governo federal e empreenderam profundas mudanças no modo de produzir e organizar a produção. As regiões onde a agricultura se manteve vinculada aos produtos tradicionais (algodão, milho), como o oeste paulista, não apresentaram dinamismo suficiente para usufruir das condições favoráveis à modernização criadas pelo governo federal a partir de meados dos anos 1960" (Hespanhol, 1996, p.205).

Assim, na visão de Hespanhol, tratamentos diferenciados pelos governos federal e estaduais propiciaram a modernização da agricultura das regiões centrais do País, enquanto grandes áreas, no Estado de São Paulo, dissociadas da agroindústria ou cooperativas, mantiveram-se às margens do processo.

Aparentemente, há uma diferença entre a abordagem de Hespanhol (1996) sobre o papel da agroindústria na modernização da agricultura e o ponto de vista de Alves (1996). Correndo o risco de simplificação excessiva, nas regiões mais desenvolvidas do estado, a presença da agroindústria teria possibilitado a modernização da agricultura, de acordo com Hespanhol. Alves mencionou a relação agroindústria e agricultura, o impacto da modernização da agricultura "sobre a agroindústria e sobre a indústria fornecedora de insumos" (1996, p.8). Embora os autores tenham indicado a relação entre modernização da agricultura e industrialização, parece haver discordância quanto à "causalidade". O primeiro é mais enfático ao insistir na relação entre o engajamento da região no processo de industrialização e seu reflexo na modernização agrícola. Alves apenas menciona a relação ao final da discussão do trabalho de Negri et al. (op. cit.). É possível que tivesse em mente períodos históricos ou estágios de 
desenvolvimento diferentes daqueles analisados por Hespanhol. Nesse caso, talvez uma agricultura já moderna "realimentaria" o crescimento das indústrias. Entretanto, nenhum deles apresenta teste estatístico ou estudo econométrico que permita uma análise mais detalhada dessa questão no Estado de São Paulo.

A associação entre a agricultura e o atraso de regiões do Estado de São Paulo é mencionada tanto por Hespanhol (1996) quanto por Alves (1996). Ambos destacam o empobrecimento de regiões agrícolas. Este último, ao discutir os resultados apresentados por Silva (op. cit.), afirmou:

"Verificou-se também que as regiões eminentemente agrícolas apenas mantiveram ou até reduziram sua participação. Esta informação corresponde ao esperado numa análise de valor adicionado, visto que o setor agrícola é o que adiciona relativamente menor valor no seu processo produtivo" (Alves, 1996, p.9).

O atraso da região Oeste do estado é ressaltado por Martin (1993) e por Passos (1991). ${ }^{52}$ O primeiro, apoiando-se nos estudos da Coordenadoria de Abastecimento da Secretaria da Agricultura, ressalta que

\begin{abstract}
“a recessão econômica vivida pelo Estado desde o início dos anos 80 e como conseqüência os grandes ajustes que vêm passando a agricultura paulista, com a crise dos produtos tradicionais e fortemente empregadores de mão-de-obra como o café e o algodão, geraram um total de 226 municípios paulista com mais de $20 \%$ de suas famílias classificadas como indigentes, com ganhos familiares que permitem no máximo a aquisição de uma cesta básica” (Martin, 1993, p.28).
\end{abstract}

Martin (1993) ressalta ainda que a "concentração da indigência ocorre basicamente nas regiões agrícolas, principalmente no oeste Paulista ao longo de toda

\footnotetext{
${ }^{52}$ PASSOS, S.M.G. Histórico dos feitos e realizações da Coordenadoria de Assistência Técnica Integral. Campinas: SEAB/ CATI, 1991.
} 
divisa com o Paraná, Vale do Ribeira e Paraíba" (Martin, 1993, p.28). O segundo autor chama a atenção para as conseqüências da industrialização do País “a qualquer custo". Tais conseqüências teriam sido:

“o empobrecimento relativo das principais regiões agrícolas de abertura recente no Estado de São Paulo, principalmente as do Oeste; falta de recursos para aplicação na infra-estrutura agrícola das regiões a Oeste do Estado (pois, os recursos existentes eram utilizados nos projetos prioritários urbano-industriais)" (Passos, op. cit., citado por Hespanhol, 1996, p.206).

Algumas das áreas menos desenvolvidas do estado encontram-se nas regiões de ocupação mais recente que surgiram ou cresceram, associados a obras de transporte, mais precisamente às ferrovias. Vários municípios do Oeste do estado surgiram em função das estações de trem, como é o caso do trecho conhecido como Alta Paulista, justamente uma alusão à ferrovia. Outro exemplo é a região noroeste:

“A construção da Estrada de Ferro Noroeste do Brasil foi crucial para a ocupação de toda a região que ficou conhecida como Noroeste - em virtude da própria ferrovia - área que se estende de Bauru até as barrancas do rio Paraná, em território paulista” (Hespanhol, 1996, p.100).

O objetivo primordial das ferrovias que atravessaram o Estado de São Paulo foi o transporte da produção de café, mas, além disso, em determinados locais, elas parecem ter catalisado o processo de desenvolvimento enquanto em outros não. Isso se aplica à Estrada de Ferro Noroeste do Brasil cuja linha tronco, embora "tenha atingido as barrancas do rio Paraná já na primeira década deste século, [ela] não provocou o desencadeamento do processo de ocupação da Região de Andradina" (Hespanhol, 1996, p.107). Monbeig (1984), ao referir-se à colonização do baixo Tietê, considerou a construção da linha férrea muito apressada e o resultado foram terras demais por desbravar entre Bauru e Araçatuba. 
Tentativas de promover o desenvolvimento em regiões de ocupação mais recente do estado parecem ter sido influenciadas pelas mesmas idéias que moldaram as políticas de desenvolvimento regionais do País no período correspondente a essa "ocupação". Tais idéias, conforme já discutido, além de influenciadas pela teoria dos pólos, voltaram-se basicamente a investimentos em capital físico. Particularmente para o Estado de São Paulo, destaca-se, dentre esses investimentos, a construção de hidroelétricas. A construção do Complexo de Urubupungá e Porto Primavera implicou na construção de cidades planejadas pela CESP. Tanto Ilha Solteira (do Complexo Urubupungá) quanto Porto Primavera estão entre os dez maiores reservatórios do País, conforme Müller (1995, p.37-38). Entendeu-se, na época, que, dada a dificuldade de deslocar trabalhadores até a região, era necessário criar cidades com toda a infraestrutura de apoio. É importante lembrar que as cidades construídas foram habitadas inicialmente pelos trabalhadores da construção civil e corpo técnico da CESP. Com o término das obras, houve uma conseqüente evasão dessa mão-de-obra, já que a administração local das usinas requer um número bastante reduzido de profissionais.

Para a região do Vale do Tietê, há exemplos de investimentos em capital físico no passado que não resultaram no desenvolvimento esperado, e as usinas hidrelétricas estão entre eles. O fracasso da primeira tentativa parece remontar à antiga colônia militar de Itapura, SP, às margens do rio Paraná. De lá para cá, há pelo menos outros dois empreendimentos cujos resultados frustraram as expectativas: a construção da ferrovia Noroeste e a construção das usinas hidrelétricas. Hespanhol (1996) refere-se à primeira afirmando que ela não provocou o desencadeamento do processo de ocupação da Região de Andradina, SP. Quanto à construção das Usinas Hidrelétricas de Jupiá e Ilha Solteira (no rio Paraná), nos anos sessenta e setenta, e de Três Irmãos (rio Tietê), a partir do ano de 1980, o autor atribui o fracasso das expectativas à falta de adoção de planos integrados que catalisassem os aspectos positivos do empreendimento e amenizassem os negativos gerados pelo término das obras.

O potencial de promover o desenvolvimento regional através da construção de hidrelétricas é inegável, mas há vários problemas que surgem com as obras e, em 
alguns casos, principalmente com o término delas. Particularmente quanto às duas grandes obras em território paulista (Ilha Solteira e Porto Primavera), ocorreram problemas comuns a obras deste tipo em relação à realocação dos trabalhadores rurais e, além disso, com o término das obras, as cidades corriam o risco de transformarem-se em “cidades fantasmas”. Cabe lembrar que esses municípios são formados por cidades totalmente artificiais, sem produção agrícola relevante e com poucas indústrias locais, sendo mantidos por recursos do governo federal repassados a esses municípios. As tentativas de mantê-los como municípios emancipados geraram, por outro lado, a continuidade de investimentos públicos e gastos com os assentamentos e assistência técnica aos assentados.

$\mathrm{Na}$ implantação das usinas, em regiões atrasadas do estado, a atuação governamental foi além da construção das obras. Por outro lado, viu-se que com o término das obras as cidades enfrentaram problemas para a sobrevivência. Além da falta de uma produção econômica local, exceto geração de energia, a presença maciça da CESP como a construtora de imóveis foi, provavelmente, um fator desestimulador ao desenvolvimento de um mercado imobiliário. Assim, em Ilha Solteira, passados vinte e cinco anos, quando os antigos alojamentos dos trabalhadores das obras, construídos para durarem poucos anos, não apresentavam as mínimas condições de higiene e segurança, coube ao poder local a tentativa de solução do problema habitacional. Também os assentamentos da CESP passaram, em Ilha Solteira, a ser assistidos pela prefeitura municipal, ou seja, houve uma "transferência" do papel da CESP para o poder público municipal. Além disso, a idéia de se aproveitar as instalações da CESP levou o governo estadual a instalar um campus universitário após a rejeição da proposta de se construir uma colônia penal. O aproveitamento das instalações, na prática, não se efetivou como o esperado. Dentre outras dificuldades de aproveitamento das instalações, a CESP solicitava a absorção de seu quadro de funcionários de laboratórios pela Universidade.

A CESP enfatiza o potencial de desenvolvimento da região do Vale do Tietê, através do aproveitamento das oportunidades geradas pela hidrovia Tietê-Paraná. A visão das possibilidades parece influenciada pela Teoria dos Pólos. Por exemplo, ao se 
referir ao rio Piracicaba, de acordo com a CESP (1997), ocorreria a implantação de um "pólo hidroindustrial" que atrairia investimentos privados. Afirma ainda que, mais a jusante desse pólo, estaria sendo viabilizado um pólo turístico de grande porte. A influência da teoria dos pólos pode ser observada também em trechos nos quais a empresa se refere aos dezessete pólos regionais de turismo que constituiriam pontos estratégicos a serem operados de forma integrada. O contexto em que a CESP foi fundada, no qual prevalecia a teoria dos pólos, parece ainda influenciar a visão dessa empresa sobre o desenvolvimento regional.

Pela própria natureza do serviço prestado pela CESP, seus estudos revelam preocupação apenas quanto ao capital natural e físico ao longo da hidrovia. A empresa faz referências a possibilidades para navegação de recreio ao longo da hidrovia, nos moldes realizados em outros países. Como exemplo, é citada a "prática usual nos Estados Unidos e Europa" a bordo de houseboats. Preocupa-se em explicar o tipo de embarcação a ser utilizado "para a realização de viagens turísticas de longo curso, similares às praticadas no rio Reno" (CESP, 1987, p.13). Por outro lado, estudo ambiental do empreendimento de aproveitamento múltiplo Santa Maria da Serra, Piracicaba, SP, menciona potencial para instalação de pólo industrial e turístico, mas o parecer dado por Souza (1999) sobre o referido empreendimento questiona as informações. De acordo com o parecer, “os pólos industriais e turísticos não apresentam justificativas que permitam inferir um nexo de causalidade entre o terminal intermodal e o desenvolvimento de indústria de pólo a ser criado, bem como o pólo turístico" (p.2). A CESP apresentou, de acordo com o Secretário de Recursos Hídricos do Estado, Mendes Thame ${ }^{53}$, apenas o empreendimento barragem, e há várias indagações não respondidas e implicações que extrapolam a simples construção da barragem e dizem respeito ao desenvolvimento, às vantagens sociais e econômicas.

A necessidade de organização da sociedade para o bom aproveitamento do potencial de desenvolvimento do Vale do Tietê está clara nos fracassos para construção

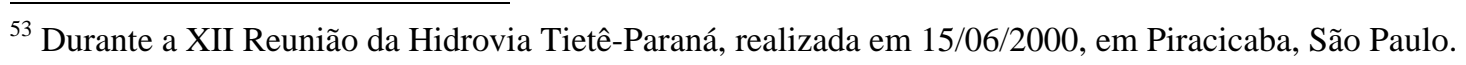


de barragens e obtenção de recursos financeiros. Sobre a construção da barragem de Santa Maria da Serra, de acordo com o Secretário Mendes Thame, mesmo com os recursos já constando no orçamento do Estado, não se conseguia a aprovação para a construção da obra. Se o uso da hidrovia representaria para o Estado de São Paulo o aproveitamento de vantagens competitivas com outros estados, sem artifícios fiscais, etc., privilegiando dessa forma as vantagens naturais existentes, quais seriam as razões para tantas dificuldades em aprovar uma obra? Para o secretário, a aprovação da barragem precisa de um estudo com os aspectos relacionados ao potencial de desenvolvimento sócio-econômico que complemente os anteriores. Além disso, a sociedade precisa organizar-se não apenas para viabilizar o licenciamento, mas também o aproveitamento das oportunidades, inclusive com a formação de joint-ventures. Mendes Thame insistiu na necessidade de participação da comunidade (que considerou baixa) e, reconheceu a necessidade de esclarecer os ambientalistas quanto às vantagens da hidrovia como meio de transporte e como "vetor de desenvolvimento" ainda não explorado pelos municípios lindeiros. Esse tipo de preocupação também está presente na discussão de Hespanhol (1996) sobre o fracasso da tentativa de obtenção de recursos financeiros junto ao Banco Mundial, pelos municípios que fazem parte do CINDIRU (Consórcio Intermunicipal para o Desenvolvimento da Irrigação na Região de Urubupungá), para o projeto de irrigação encaminhado ao referido banco. A postura do autor é a de que "cabe à comunidade regional através dos empresários e/ou do Poder Público compreender, usar e transformar o potencial existente em desenvolvimento efetivo".

Como mencionado anteriormente, um dos fatores importantes para explicar o desenvolvimento de regiões do Estado de São Paulo, não considerado em tentativas que privilegiaram a construção de "grandes obras", é a organização em grupos sociais. Alves (1996) considerou este aspecto no trabalho realizado no município de Vera Cruz. O autor buscava uma relação entre grupos sociais organizados e evolução da qualidade de vida no município. Por grupo social organizado entende-se, nesse caso, organizações do tipo associações de beneficio mútuo e organizações de serviços e inclui aqueles que 
se destinam à recreação (pela possibilidade de interação de forma positiva com outros grupos e indivíduos que fazem parte dessa comunidade).

Alves (1996) realizou um levantamento de dados sobre os indicadores sócioeconômicos de Vera Cruz e buscou uma relação entre eles e a atuação de grupos organizados. Como referência, utilizou-se dos indicadores do Estado de São Paulo e das Regiões Administrativas e do Governo de Marília. Para a avaliação dos grupos, realizou entrevistas com membros de 30 grupos organizados do município. Como resultado, constatou a evolução desfavorável de vários indicadores sócio-econômicos do município quando comparados aos referenciais, embora em valores absolutos, quase todos eles tenham melhorado no período estudado (1980-1993).

Alves (1996) detectou associação entre os indicadores com a atuação de grupos sociais organizados, mas não avaliou possíveis causalidades nas relações entre os indicadores e os grupos. O próprio autor reconhece essa limitação. Considerou a possibilidade de uma relação positiva entre a estruturação dos grupos e alguns índices estudados. Observou, em alguns casos, a atuação dos grupos sociais organizados para minorar efeitos da pobreza e notou a alta proporção de grupos com algum tipo de inconsistência entre os níveis hierárquicos dos objetivos. É importante ressaltar que não verificou problemas de estímulo à participação e sim quanto à estruturação e atuação dos grupos. Esta é uma observação relevante, uma vez que parece existir, nos profissionais que trabalham com a organização de grupos sociais, grande preocupação com a participação dos membros. Por exemplo, é bastante comum pressupor-se uma baixa participação dos cooperados em reuniões e assembléias de cooperativas agrícolas.

Tanto o trabalho de Alves (1996) quanto de Hespanhol (1996) abordaram questões de desenvolvimento do Estado de São Paulo em regiões que, nas últimas décadas, não acompanharam o crescimento econômico de outras. Ambos realizaram o trabalho na mesma época (ano de 1996) e, em alguns casos, utilizaram-se das mesmas fontes de informação (não apenas quanto aos dados estatísticos para o estado, mas também porque ambos foram influenciados por trabalhos de Azzoni). Entretanto, há uma 
diferença bastante clara na abordagem desses autores. Alves enfatiza a participação popular e Hespanhol, o papel do estado no desenvolvimento. Deve ser ressaltada a falta da associação com estoques de capitais existente nos trabalhos discutidos sobre desenvolvimento em São Paulo. No estudo de Alves, faltou a visão teórica de estoque de capital social que parece adequada às questões às quais se propôs responder. No trabalho de Hespanhol, a associação é bem menos óbvia, mas é possível. Para a associação entre a visão de estoques de capitais e a análise realizada por Hespanhol é necessária uma interpretação cuidadosa, que detecte, "nas entrelinhas", as relações entre sua análise e as cinco formas de capital.

As cinco formas de capital podem ser associadas à análise realizada por Hespanhol (1996) sobre o atraso de regiões do Estado de São Paulo. O autor afirma, por exemplo, que partiu da tese de que "outras regiões, com características semelhantes (...) tiveram seu desenvolvimento impulsionado pela evolução das próprias tendências regionais ou pela atuação deliberada do Estado, que redundaram principalmente na dinamização das atividades agroindustriais" (Hespanhol, 1996, p.xvii). Por tendências regionais, pode-se entender, pelo menos em parte, o papel do estoque de capital natural. Essa interpretação do texto é reforçada pelo fato de que, ao longo do trabalho, várias vezes o autor refere-se aos recursos naturais da região de Andradina, por exemplo, sobre o potencial para irrigação. Quanto ao não-aproveitamento desses recursos para irrigação, nota-se, nas palavras do autor, indícios da necessidade de melhor organização da sociedade para o desenvolvimento. É o caso de sua opinião sobre o fracasso da tentativa de obtenção de recursos financeiros junto ao Banco Mundial, já mencionada. Uma possível relação entre a dificuldade de captação de recursos financeiros e a desorganização das comunidades locais remete um observador atento aos estoques de capitais à necessidade de estudos sobre capital financeiro e capital social. Mais difícil parece ser detectar aspectos associados ao capital humano, no trabalho de Hespanhol. Entretanto, as críticas que este autor apresentou sobre a diminuição dos recursos da Secretaria da Agricultura e a associação que ele fez entre a assistência técnica oferecida pelo setor privado a produtores das regiões de agricultura mais moderna, conduzem, 
inevitavelmente, a este conceito de capital. Assim, observa-se que os dois estudos, exaustivamente discutidos nessa revisão, apresentam indícios de problemas que devem ser tratados à luz dos estoques de capitais.

Dos estudos sobre o Estado de São Paulo, verifica-se que, no processo de “interiorização do desenvolvimento", algumas regiões mantiveram-se às margens deste, apesar dos investimentos em capital físico realizados. Esse é o caso do Vale do Tietê, no qual se localizam vultuosos investimentos em capital físico na forma de hidrelétricas e obras de infra-estrutura necessária para a navegabilidade do rio. As obras foram realizadas pela CESP, o que estava perfeitamente de acordo com a visão predominante, naquela época, do Estado como "construtor" de obras e destas como determinantes do desenvolvimento.

Da literatura internacional, sabe-se que a ênfase no capital físico para gerar crescimento econômico esgotou-se, há muitos anos, e as atenções voltaram-se para o capital financeiro, humano e, bem mais recentemente, o social. A literatura da década de 1940 apontava deficiências de capital físico como obstáculo ao desenvolvimento, mas, de lá para cá, os modelos explicativos do crescimento econômico incorporaram a importância do capital humano a esse processo. Por outro lado, a importância crucial do capital financeiro para os países menos desenvolvidos foi também enfatizada. A partir do trabalho de Putnam (1993), o conceito de capital social passou a contribuir em muito para o entendimento dos diferentes graus de desenvolvimento entre as regiões. Entretanto, apesar dos avanços teóricos obtidos, a relação entre o desenvolvimento do Estado de São Paulo e os estoques de capitais não é encontrada na literatura brasileira.

Sendo o objetivo geral deste estudo identificar e avaliar os fatores limitantes ao desenvolvimento do Vale do Tietê, à luz dos estoques de capitais, deve-se ressaltar que foram vários os avanços teóricos obtidos nessa área de pesquisa. Os trabalhos de Lucas (1988) e de Putnam (1993) possibilitaram o entendimento de "pontos de estrangulamento" do desenvolvimento até então obscuros. Paralelamente aos avanços que elucidaram a importância do capital humano e sua relação com o capital físico, bem 
como a importância do capital social para o desenvolvimento, a relevância do capital natural voltou a ser enfatizada por pesquisadores preocupados com os riscos de escassez de recursos naturais. Embora ainda existam limitações quanto à formas de avaliação, é importante reconhecer que também o instrumental de análise desses estoques evoluiu. Essa evolução permite que se incorpore, às análises já tradicionais sobre desenvolvimento (que abordam o papel do capital físico e do capital financeiro), as outras formas de capital. Reconhecendo-se a importância das cinco formas de estoque de capital e a desigualdade existente, ao longo do Vale do Tietê-Paraná, quanto ao grau de desenvolvimento, este estudo realizou uma análise empírica para os municípios do Estado de São Paulo, que será apresentada. 


\section{METODOLOGIA}

A idéia central da análise empírica realizada neste estudo, cuja metodologia será apresentada a seguir, foi explicar o desenvolvimento econômico dos municípios paulistas através de variáveis representativas dos cinco estoques de capitais. Com este intuito, realizou-se amplo levantamento dos dados disponíveis sobre os municípios e selecionaram-se variáveis encontradas nas bases de dados da Fundação Sistema Estadual de Análise de Dados - Seade (Seade, 2002a; Seade, 2002b); da Relação Anual de Informações Sociais - RAIS, divulgada pelo Ministério do Trabalho e do Emprego (Brasil, 1996; Brasil, 2002); do Instituto de Economia Agrícola - IEA (Hiriart et al., 1999); do Departamento de Apoio às Estâncias - DADE - da Secretaria de Ciência, Tecnologia, Desenvolvimento Econômico e Turismo do Estado de São Paulo ${ }^{54}$ e do Instituto Brasileiro de Geografia e Estatística - IBGE (IBGE, 2002). Algumas dessas variáveis já estavam na forma de coeficiente baseado na população, ou seja, expressas, por exemplo, por cem mil habitantes, mas a grande maioria precisou ser transformada utilizando-se para tanto as estimativas populacionais para o ano de 1996, divulgadas pelo IBGE, obtidas na base de dados da Fundação Seade.

Para representar os estoques de capital físico e de capital financeiro, todas as variáveis selecionadas estão disponíveis na base de dados da Fundação Seade. Representaram o capital físico: o número de terminais telefônicos; consumo de energia elétrica residencial; consumo de energia elétrica rural; consumo de energia elétrica industrial; consumo energia elétrica pelo comércio, serviços e outras atividades; arrecadação de Imposto Predial Urbano (IPU); arrecadação de Imposto Predial e

\footnotetext{
${ }^{54}$ Comunicação pessoal, 2002.
} 
Territorial Urbano (IPTU): receita municipal patrimonial; arrecadação municipal (contribuição de melhoria); número de distritos industriais e número de domicílios particulares permanentes em aglomerado subnormal. Para o estoque de capital financeiro, considerou-se: crédito rural; depósitos totais; operações de crédito; receita municipal de transferências de convênios; operações de crédito contratadas pelo município, receita municipal de transferências intergovernamentais; receita municipal de demais transferências de capital; total da receita municipal arrecadada; total da receita tributária e despesas municipais com o serviço da dívida.

A fonte dos dados utilizada para representar o capital humano também foi basicamente a Fundação Seade, mas se incluíram também as variáveis de educação disponíveis em Haddad \& Bonelli (1998b). Essas últimas foram as percentagens da população a partir de 25 anos com menos de 4 anos de estudo, com menos de 8 anos de estudo e com mais de 11 anos de estudo; a taxa de analfabetismo da população a partir de 15 anos e o número médio de anos de estudo da população a partir de 25 anos de idade. As outras variáveis foram: taxa de natimortalidade; taxa de mortalidade geral; taxa de mortalidade infantil; dentistas registrados no Conselho Regional de Odontologia; enfermeiros registrados no Conselho Regional de Enfermagem; médicos registrados no Conselho Regional de Medicina; percentagem de população rural e os totais de matrículas iniciais no primeiro e no segundo graus.

Para representar o estoque de capital natural, entendeu-se que o preço da terra e a existência de recursos minerais poderiam refletir, em grande parte, as diferenças na disponibilidade deste capital, mas procurou-se também um grupo de variáveis que pudessem exprimir o grau de depreciação deste estoque. Nesse sentido, incluíram-se variáveis de conservação do solo (percentual dos estabelecimentos com conservação do solo sobre o total de estabelecimentos) do Censo Agropecuário 1995-96 (IBGE, 2002), o número de unidades de conservação ambiental existente no município (zero, uma ou a partir de duas) e a percentagem de esgoto sem tratamento de Seade (2002b). Essa base também forneceu os dados de cota parte do Imposto Territorial Rural (ITR) e das 
receitas municipais com indenizações pela extração de petróleo, xisto e gás. A ocorrência de minerais foi representada pela variável compensação financeira pela exploração de recursos naturais (DNPM, 2002, tabela 42) e em parte por uma variável dummy criada para diferenciar, dentre todos os municípios, aqueles são estâncias hidrominerais, climáticas ou balneárias. Essa variável, cujos dados foram obtidos através do $\mathrm{DADE}^{55}$, foi utilizada para indicar não apenas a riqueza mineral e qualidade da água das estâncias hidrominerais, do clima nas estâncias climáticas e balneáreas, mas também a existência de belezas naturais nessas estâncias. Enquadram-se nessa categoria os municípios de Águas de Lindóia, Águas da Prata, Águas de Santa Bárbara, Águas de São Pedro, Amparo, Atibaia, Campos do Jordão, Ibirá, Lindóia, Monte Alegre do Sul, Poá, Serra Negra, Bertioga, Cananéia, Caraguatatuba, Guarujá, Iguape, Ilhabela, Ilha Comprida, Itanhaém, Mongaguá, Peruíbe, Praia Grande, Santos, São Sebastião, São Vicente, Ubatuba, Analândia, Bragança Paulista, Caconde, Campos Novos Paulista, Cunha, Morungaba, Nuporanga, Santa Rita do Passa Quatro, Santo Antônio do Pinhal e São Bento do Sapucaí. Quanto às estâncias turísticas, foram consideradas como qualquer outro município (ou seja, o valor da variável dummy foi zero e não 1 como nas estâncias hidrominerais, climáticas e balneárias) pois, caracterizam-se por outros atrativos (históricos, religiosos, etc.) não necessariamente naturais. O preço da terra por município não é disponível e por essa razão utilizou-se o preço médio da terra de cultura de primeira por EDR (Escritório de Desenvolvimento Rural) calculado pelo IEA. ${ }^{56}$ Considerou-se um único preço para todos os municípios que compõem cada EDR.

As variáveis escolhidas para representar o estoque de capital social, foram selecionadas tomando-se como referência variáveis utilizadas por Putnam (1993) para representar associativismo, civismo e confiança. Consideraram-se também algumas das proxies para estes três componentes do capital social utilizadas por Pavarina (2002) ${ }^{57}$ Para civismo e associativismo (com exceção do número de cooperativas), todas as variáveis foram obtidas na RAIS (Brasil, 1997; Brasil, 2002) e seguindo a classificação

\footnotetext{
${ }^{55}$ Conforme comunicação pessoal.

${ }^{56}$ Conforme comunicação pessoal, 2002.

${ }^{57}$ PAVARINA, P.R.J.P. Descrição do capital social ao longo do vale dos rios Tietê e Paraná. No prelo.
} 
da Classificação Nacional de Atividades Econômicas (CNAE) de 1995. Algum grau de "civismo" foi representado, ainda que precariamente, pelas variáveis voltadas à comunicação em massa - dado seu caráter de utilidade pública - e utilizou-se para isso o número de estabelecimentos de atividades de rádio, de atividades de televisão e de atividades de agência de notícias. Além dessas variáveis da RAIS, utilizou-se o número de estabelecimentos existentes em cada uma das atividades incluídas pela CNAE como atividades associativas e atividades recreativas culturais (nas quais também se enquadram as já citadas atividades de meio de comunicação) e desportivas. Dessa forma, incluíram-se variáveis que consistem no número de estabelecimentos de: atividades de organizações empresariais e patronais; atividades de organizações profissionais; atividades de organizações sindicais; atividades de organizações religiosas; atividades de organizações políticas; outras atividades associativas não-especificadas anteriormente; atividades de produção de filmes para cinema e fitas de vídeo; distribuição de filmes e vídeos; projeção de filmes e vídeos; atividades de teatro, música e outras atividades literárias; gestão de salas de espetáculos; outras atividades de espetáculo não especificadas anteriormente; atividades de bibliotecas e arquivos; atividades de museus e conservação do patrimônio histórico; atividades jardins botânicos, zoológicos, parques nacionais e reservas ecológicas; atividades desportivas; outras atividades relacionadas ao lazer. O total de cooperativas existentes no município obtido a partir dos dados da OCB (2001) foi levantado por Pavarina (op. cit.). Também a partir dos dados levantados pela autora mencionada, obteve-se o número de associações rurais, ocorrências e de inquéritos policiais. De acordo com Pavarina, as fontes utilizadas foram Hiriart et al. (1999) e Seade (2002a) e Seade (2002b). A essas duas últimas variáveis - que representaram confiança - acrescentaram-se, neste estudo, as variáveis número de crimes contra o patrimônio; número de estelionatos; número de crimes totais; número de contravenções também disponibilizadas pelo Seade.

Como variável representativa do desenvolvimento econômico, o Índice de Desenvolvimento Humano pareceu inicialmente apropriado, mas principalmente por trazer em sua composição variáveis representativas de capital humano, não é adequado 
aos propósitos na análise empírica realizada. Mesmo assim, foi uma como uma das três variáveis dependentes testadas neste estudo. O cálculo mais recente desse índice encontrado para os municípios do Estado de São Paulo refere-se ao ano de 1996 (São Paulo, 1999). Por esta razão, decidiu-se utilizar variáveis dependentes referentes a esse mesmo ano e, sempre que possível, variáveis explicativas também do mesmo ano. Algumas variáveis explicativas não foram encontradas para 1996 e foram substituídas por 1995 ou 1997. Apenas para as variáveis de educação de Haddad \& Bonelli (1998b) foi necessário utilizar o ano de 1991.

$\mathrm{Na}$ impossibilidade de se encontrar uma variável que representasse satisfatoriamente o desenvolvimento econômico entendido em seu sentido mais amplo, optou-se por buscar variáveis que indicassem crescimento econômico. Ressalta-se que esse é um procedimento bastante adotado em estudos de desenvolvimento. O uso, por exemplo, do crescimento da renda per capita como medida de desenvolvimento apresenta como vantagem, de acordo com Schuh (s.d.) ${ }^{58}$, o fato de ser largamente aceita como medida de melhora no nível do bem estar. Para Schuh, o crescimento da renda per capita, para uma dada unidade política, é uma definição adequada para o desenvolvimento. Uma vez que não se pretendeu neste estudo estender a discussão sobre as diferenças entre os conceitos de desenvolvimento e crescimento econômico, considerou-se este último como condição necessária para o desenvolvimento e escolheuse como suas proxies o número de estabelecimentos de intermediação financeira ${ }^{59}$ e o número de empregos existentes nos municípios, ambas obtidas na RAIS.

Uma vez que selecionou-se 70 variáveis para representar os estoques de capitais, buscou-se um método estatístico que permitisse extrair do conjunto aquelas mais relevantes. Escolheu-se o método dos componentes principais por possibilitar

\footnotetext{
${ }^{58}$ SCHUH, G.E. Lecture notes on economic development: some background issues. s.n.t.

${ }^{59}$ São consideradas instituições de intermediação financeira: Banco Central; bancos comerciais; bancos múltiplos (com carteira comercial); caixas econômicas; crédito cooperativo; bancos múltiplos (sem carteira comercial); bancos de investimento; bancos de desenvolvimento; crédito imobiliário; sociedades de crédito, financiamento e investimento; arrendamento mercantil; agências de desenvolvimento; outras atividades de concessão de crédito; fundos mútuos de investimento; sociedades de capitalização; e outras atividades de intermediação financeira, não especificadas anteriormente.
} 
identificar, de um conjunto bastante amplo de variáveis, um conjunto menor de fatores que respondam pela máxima variância dos dados. Após a identificação desses fatores pode-se utilizá-los em análises multivariadas subseqüentes (Sharma, 1996; Hoffmann, 1999; Malhotra, 2001). A análise subseqüente realizada neste estudo foi uma regressão linear múltipla. Incluiu-se na regressão uma variável dummy para captar possíveis diferenças existentes entre os municípios paulistas lindeiros ${ }^{60}$ e os outros municípios do estado, no que diz respeito aos fatores determinantes do desenvolvimento.

\subsection{Análise pelo método de Componentes Principais}

A análise dos componentes principais é uma técnica que, muitas vezes, é incluída como um método de análise fatorial, dada a estreita associação entre eles. Sharma (1996), atribui a confusão existente na literatura aos programas de análise estatística dentre eles o SPSS (Statistical Package for Social Sciences) que fazem a análise dos componentes principais considerando-a um processo da análise fatorial. Essa confusão pode ser vista em Malhotra (2001) que apresenta o método dos componentes principais como um método de análise fatorial o qual seria um nome genérico que “denota uma classe de processos utilizados para redução e sumarização dos dados" (p.504).

A distinção entre o método de componentes principais e a análise fatorial é apresentada em detalhes em Sharma (1996) e sucintamente em Hoffmann (1999). A análise fatorial, de acordo com Hoffman, é uma técnica exploratória destinada a "resumir" as informações contidas em um conjunto de variáveis, em um conjunto de fatores cujo número é geralmente bem inferior ao número de variáveis observadas. Trata-se de um método que surgiu no campo da psicologia para explicar variáveis

\footnotetext{
${ }^{60}$ São eles: Adolfo, Andradina, Anhembi, Araçatuba, Arealva, Avanhandava, Barbosa, Bariri, Barra Bonita, Birigui, Boracéia, Borborema, Botucatu, Brejo Alegre, Buritama, Cafelândia, Castilho, Conchas, Coroados, Dois Córregos, Glicério, Guaiçara, Guarani d'Oeste, Iacanga, Ibitinga, Igaraçu do Tietê, Ilha Solteira, Indiaporã, Itaju, Itapuí, Itapura, Jaú, José Bonifácio, Laranjal Paulista, Lins, Macatuba, Mesópolis, Mineiros do Tietê, Novo Horizonte, Panorama, Paulicéia, Pederneiras, Penápolis, Pereira Barreto, Piracicaba, Pirajuí, Pongaí, Populina, Presidente Epitácio, Promissão, Reginópolis, Rosana, Rubinéia, Sabino, Sales, Santa Albertina, Santa Clara d'Oeste, Santa Maria da Serra, Santa Rita d'Oeste,
} 
latentes ou fatores que explicassem habilidades e comportamentos humanos. Já o método dos componentes principais procura explicar o máximo da variância das variáveis originais. Segundo Almeida (2002), os objetivos das duas análises são diferentes. $\mathrm{Na}$ análise de componentes principais, o analista está preocupado com predição, determinando um número mínimo de fatores necessários para explicar o máximo de variação do conjunto original de dados, tendo conhecimento prévio de que as variâncias específicas e do erro são pequenas com relação à variância total. Na análise fatorial o analista está preocupado em identificar dimensões latentes no conjunto de variáveis originais, tendo pouco conhecimento sobre as variâncias específicas e do erro, desejando eliminá-las. Apesar de a separação sutil entre os métodos não ser devidamente considerada em Malhotra (2001), ressalta-se que os três autores mencionados concordam que o método dos componentes principais é adequado para se identificar, a partir de um conjunto amplo de variáveis, um conjunto menor de fatores que respondam pela máxima variância nos dados. Sendo este o objetivo desta análise estatística, o método é perfeitamente adequado.

Componentes principais é o nome que recebem os fatores identificados na análise fatorial e consistem em combinações lineares das variáveis originais. São não correlacionados uns com os outros apesar da correlação estar presente nas variáveis originais. O primeiro componente principal explica o máximo de variância nos dados, o segundo o máximo não explicado pelo primeiro e daí por diante. As etapas do método para se chegar até o componente principal serão apresentadas sinteticamente com base em Hoffmann (1999) e em Sharma (1996).

O primeiro passo para se determinarem os componentes principais é a transformação das variáveis observadas. Com a transformação, todas as variáveis passam a ter "a mesma variância e a participação de uma variável na determinação dos componentes principais irá depender apenas das suas correlações com as demais variáveis" (Hoffmann, 1999, p.3).

Santo Antonio do Aracanguá, São Manuel, São Pedro, Sud Mennucci, Teodoro Sampaio, Ubarana, Uru, Zacarias (Farremberg, 1998). 
Sendo $\bar{X}_{\mathrm{i}}$ a média da i-ésima variável observada, a obtenção de variáveis centradas e transformadas consiste em fazer:

$$
x_{i j}=\frac{X_{i j}-\overline{X_{i}}}{\sqrt{\sum_{j}\left(X_{i j}-\overline{\left.X_{i}\right)^{2}}\right.}}
$$

A matriz formada por essas variáveis centradas e transformadas é $\mathbf{X}$ e a matriz das correlações simples entre essas variáveis, $\mathbf{R}$, é dada por

$$
\mathbf{R}=\mathbf{X X}^{\prime}
$$

Para essas variáveis $x_{i j}$, formam-se combinações lineares cuja representação matricial é

$$
\mathbf{g}_{i}^{\prime}=\mathbf{c}_{i}^{\prime} \mathbf{X}
$$

onde: $g_{i}^{\prime}$ é um vetor com L elementos, correspondendo ao i-ésimo componente principal e $\mathbf{c}_{i}^{\prime}$ é o vetor dos pesos da combinação linear.

Encontrar $\mathbf{c}_{i}^{\prime}$ é a próxima etapa. Como, por definição, o primeiro componente principal de $\mathbf{X}$ é a combinação linear com máxima variância, trata-se de um problema de maximização da variância da nova variável com uma restrição que impõe um limite à variância, ou seja c'c $=\mathbf{1}$. Sem essa restrição a variância cresceria ilimitadamente. A solução desse problema, através do método de Lagrange, resulta em

$$
\mathbf{c}_{\mathbf{1}}^{\prime} \mathbf{R c}_{\mathbf{1}}=\ddot{e}_{1}
$$

onde $\mathbf{c}_{1}^{\prime}$ é um vetor linha com os coeficientes da combinação considerada e é chamado de primeiro vetor característico. Lembrando que, neste estudo, o número de variáveis originais é 70 , esse vetor apresenta esse número de coeficientes. O lado 
esquerdo da equação é a variância da nova variável $\mathbf{g}_{1}$ e, o lado direito, a raiz característica ou autovalor ("eigenvalue") correspondente ao primeiro vetor característico, sendo que $\lambda_{1}>\lambda_{2}>\ldots>\lambda_{n}>0$.

Considerando que

$\operatorname{Var}\left(\mathbf{g}_{1}\right)=\frac{1}{\mathbf{L}} \mathbf{c}_{1}^{\prime} \mathbf{R c}_{1}$

$\mathbf{R c}_{1}=\ddot{\mathbf{e}} \mathbf{c}_{1}$

então:

$$
\operatorname{Var}\left(\mathbf{g}_{1}\right)=\frac{\ddot{\mathbf{e}}}{\mathbf{L}_{1}}
$$

e a fração da variância das $n$ variáveis $x_{i}$ “explicada" pelo k-ésimo componente principal é $\lambda_{\mathrm{i}} / n$

O segundo componente principal, $\mathbf{g}_{2}$, é encontrado também através da resolução de um problema de maximização da variância, mas com a restrição adicional de que não deve ser correlacionado com o primeiro componente principal $\mathbf{g}_{1}$ já identificado. Obtido o segundo componente principal, identifica-se o terceiro (que não deverá ser correlacionado com os dois anteriores) e assim sucessivamente generalizando-se a solução para obtenção dos componentes principais ou fatores. $\mathrm{O}$ problema de encontrar os pesos da combinação linear "reduz-se a encontrar os autovalores da matriz de covariância. Os autovalores fornecem os vetores de pesos e representam a variância das novas variáveis ou a carga dos componentes principais" (Sharma, 1996, p.85). Portanto, o método da análise dos componentes principais consiste, no cálculo dos autovalores e correspondentes autovetores de uma matriz de variâncias-covariâncias. Nessa matriz simétrica, os elementos da diagonal principal são 
as variâncias das variáveis e os demais elementos valores de covariâncias entre pares de variáveis.

O número de componentes principais a ser obtido é, na prática, uma decisão que pode ser considerada arbitrária. Um critério encontrado na literatura é a obtenção de tantos fatores quantas forem as de raízes características maiores que a unidade. Neste estudo, optou-se inicialmente por esse critério, mas, dado o grande número de fatores encontrados, optou-se por limitar o número de componentes principais ou fatores a 10 conforme será apresentado no próximo capítulo. 


\section{RESULTADOS E DISCUSSÃO}

A apresentação dos resultados obtidos na análise empírica realizada inicia-se a partir dos fatores ou componentes principais encontrados para explicar a variância nos dados. Esses fatores, cuja composição será discutida a seguir, formaram-se a partir de variáveis representativas dos cinco estoques de capitais. Em seguida à discussão sobre os componentes principais, os resultados das três regressões múltiplas realizadas serão apresentados. Nessas regressões, buscou-se explicar o papel dos fatores identificados para as variáveis de IDH, número de estabelecimentos de intermediação financeira e emprego.

\subsection{Resultados dos Componentes Principais}

O método dos componentes principais apresentou-se adequado à análise, de acordo com os valores obtidos nos testes de esfericidade e da adequacidade da amostra. Para a esfericidade da amostra, aplicou-se o teste de esfericidade de Bartlett (Bartlett Test of Sphericity) no qual a hipótese testada é a de que a matriz de correlação é uma matriz identidade - o que significaria que as variáveis seriam correlacionadas consigo próprias e não correlacionadas com as demais (Malhotra, 2001). Isso seria inadequado para a obtenção de fatores que se supõe apresentarem variáveis correlacionadas. $\mathrm{O}$ valor obtido foi bastante alto $(24.899,771)$ o que favorece a rejeição dessa hipótese. Quanto ao teste da adequacidade da amostra, utilizou-se o teste Kaiser-Meyer-Olkin (KMO Measure of Sampling Adequacy). Trata-se de um teste de homogeneidade das variáveis, de acordo com Sharma (1996). Acima de 0,5 a análise fatorial é considerada apropriada (Malhotra, 2001). O resultado obtido $(0,81165)$ é considerado meritório, para orientar a 
decisão sobre a adequacidade da amostra, considerando-se os valores sugeridos por Kaiser \& Rice (1974) ${ }^{60}$, citados Sharma (1996). Tendo em vista o resultado dos testes, entende-se que a análise fatorial foi um instrumento adequado para a análise dos dados deste trabalho.

Para chegar-se ao número de fatores a serem analisados, utilizou-se inicialmente o critério que se baseia nas raízes características (autovalores ou eigenvalues) obtidas. Este critério estabelece que o número de fatores é igual a quantas forem as raízes características maiores que a unidade. Deste modo, foram 21 fatores identificados que explicam a $65 \%$ da variância total dos dados. Como o número de fatores obtido é um número considerado alto, o critério não foi apropriado. Para gerar interpretações com aplicação prática, o número de fatores precisou ser reduzido e limitou-se a análise a 10 fatores que respondem por $46,6 \%$ da variância total.

A matriz inicial de fatores obtida indica a relação entre os fatores e as variáveis individuais. Para facilitar a interpretação dos resultados, fez-se a rotação dos fatores, obtendo-se a matriz rotacionada. Nessa matriz, os fatores têm correlação relativamente forte com poucas variáveis e correlação relativamente fraca com as outras variáveis. O processo utilizado para obtenção da matriz rotacionada foi o varimax, que faz uma transformação ortogonal da matriz inicial (Hoffmann, 1999). O Quadro 7 apresenta as cargas obtidas para as variáveis com as quais os fatores estão mais fortemente correlacionados, ou seja, as variáveis cujas cargas são superiores a 0,6, em valor absoluto. No décimo fator, nenhuma variável apresentou valor superior a essa referência. Por esse motivo, a interpretação a seguir será dos nove primeiros fatores que explicam 44,5 \% da variância total.

O primeiro fator explica $15,3 \%$ da variância total. As cargas fatoriais indicam correlações com as variáveis de educação. Dessas variáveis, a que apresenta maior carga, em módulo, é a variável percentagem da população, a partir de 25 anos,

${ }^{60}$ KAISER, H.F.; RICE, J. Little Jiffy Mark IV. Educational and Psychological Measurement, v.34, p.111-117, 1974. 
com menos de 8 anos de estudo (EDUC2). Nota-se que o fator tem uma correlação negativa com essa variável e também com as variáveis percentagem da população, a partir de 25 anos, com menos de 4 anos de estudo (EDUC1) e a taxa de analfabetismo da população a partir de 15 anos (ANALFAB). Essas duas últimas variáveis apresentam, respectivamente, em valores absolutos, a terceira maior carga fatorial e a última. Essas correlações negativas indicam que trata-se de um vetor que cresce à medida em que diminui a percentagem da população com baixa escolaridade e também, em menor intensidade, a percentagem de analfabetismo. Além disso, coerentemente, apresenta-se correlacionado positivamente com a variável número médio de anos de estudo da população (ESCOLARI). Esta variável é a "segunda força" que caracteriza o vetor. Na mesma direção e sentido dessa força, atua a variável percentagem da população, a partir de 25 anos de idade, com mais de 11 anos de escolaridade (EDUC3), conforme indica a correlação, também positiva, com essa variável.

\begin{tabular}{|c|c|c|c|c|}
\hline $\mathbf{1}^{\mathbf{0},}$ FATOR & $2^{\mathbf{0},}$ FATOR & $3^{\mathbf{0},}$ FATOR & $4^{0,}$ FATOR & $5^{\mathbf{0},}$ FATOR \\
\hline $\begin{array}{l}\text { Capital } \\
\text { Humano } 1 \\
\text { (Educação) }\end{array}$ & $\begin{array}{l}\text { Capital } \\
\text { Físico }\end{array}$ & $\begin{array}{l}\text { Capital } \\
\text { Social } 1 \\
\text { (Associativismo) }\end{array}$ & $\begin{array}{l}\text { Capital } \\
\text { Humano } 2 \\
\text { (Saúde) }\end{array}$ & $\begin{array}{l}\text { Capital } \\
\text { Financeiro } 1 \\
\text { (Arrecadação) }\end{array}$ \\
\hline $\begin{array}{l}\text { 1)-0,78559 } \\
\text { EDUC2 \% } \\
\text { 2) 0,77607 } \\
\text { ESCOLARI } \\
3)-0,73879 \\
\text { EDUC1\% } \\
\text { 4) } 0,69439 \\
\text { EDUC3 } \\
\text { 5) -0,61764 } \\
\text { ANALFAB }\end{array}$ & $\begin{array}{l}\text { 1)0,82298 } \\
\text { TRIBUTOS } \\
\text { 2)0,72758 } \\
\text { IPTU } \\
\text { 3)0,69992 } \\
\text { ESTANCIA } \\
\text { 4)0,68485 } \\
\text { IPU } \\
\text { 5)0,66835 } \\
\text { MELHORIA } \\
\text { 6)0,66181 } \\
\text { ENERESID }\end{array}$ & $\begin{array}{l}\text { 1)0,94929 } \\
\text { ORGPOLIT } \\
\text { 2)0,94227 } \\
\text { AGNOTIC } \\
\text { 3)0,8265 } \\
\text { ARTE } \\
\text { 4) } 0,86807 \\
\text { ORGRELIG } \\
\text { 5)0,73628 } \\
\text { ORPROFIS }\end{array}$ & $\begin{array}{l}\text { (SAÚDE) } \\
\text { 1)0,63285 } \\
\text { DENTISTA } \\
\text { 2)0,61416 } \\
\text { MEDICOS }\end{array}$ & $\begin{array}{l}\text { 1) } 0,85380 \\
\text { TOTALREC } \\
\text { 2)0,84569 } \\
\text { INTERGOV }\end{array}$ \\
\hline $6^{0}$ FATOR & $7^{\mathbf{0},}$ FATOR & $8^{\circ}$,FATOR & 9'FATOR & $10^{\circ,}$ FATOR \\
\hline $\begin{array}{l}\text { Capital } \\
\text { Social } 2 \\
\text { (Desconfiança) }\end{array}$ & $\begin{array}{l}\text { Capital } \\
\text { Natural } 1\end{array}$ & $\begin{array}{l}\text { Capital } \\
\text { Financeiro } 2\end{array}$ & $\begin{array}{l}\text { Capital } \\
\text { Natural } 2 \\
\text { (“depreciação") }\end{array}$ & Diversos \\
\hline $\begin{array}{l}\text { 1)0,67511 } \\
\text { CRIMEPAT } \\
\text { 2)0,61790 } \\
\text { INQUERIT } \\
\text { 3)0,60381 } \\
\text { OCORRENC }\end{array}$ & $\begin{array}{l}\text { 1)0,60924 } \\
\text { TERRA }\end{array}$ & $\begin{array}{l}\text { 1)0,88488 } \\
\text { DEPOSITO } \\
\text { 2)0,86483 } \\
\text { CREDITO }\end{array}$ & $\begin{array}{l}\text { 1)-0,776548 } \\
\text { CONSERVA }\end{array}$ & $\begin{array}{l}\text { Nenhuma } \\
\text { variável } \\
\text { apresentou carga } \\
\text { superior a } 0,6 \text {. }\end{array}$ \\
\hline
\end{tabular}

Quadro 7 - Variáveis que compõe os 10 fatores analisados. 
Por tratar-se de um fator claramente formado por variáveis de educação, o primeiro componente principal recebeu a denominação de capital humano 1 (educação). Em síntese, trata-se de um fator que cresce com a elevação da escolaridade da população e essa resposta é maior quando a escolaridade aumenta nas camadas de população com menos de 8 anos de estudo. Isso permite que se diga que, genericamente, que para reduzir-se diferenças entre os municípios paulistas, é a educação que deve ser priorizada e, particularmente, o ensino fundamental. Entretanto, só a partir dos resultados da análise de regressão é que se pode avaliar o papel desse fator na explicação das desigualdades quanto ao desenvolvimento.

O segundo componente identificado foi denominado capital físico. Ressalta-se que a percentagem da variância total explicada por esse vetor, 5,9\%, é consideravelmente inferior àquela do primeiro componente. Trata-se de um fator correlacionado com as seguintes variáveis: total de arrecadação tributária (TRIBUTOS), arrecadação municipal de Imposto Predial Urbano (IPU), arrecadação municipal de imposto predial e territorial urbano (IPTU), receita municipal de contribuição de melhorias (MELHORIA), variável dummy para estância e consumo de energia elétrica residencial (ENERESID). Além desta última variável, também os três impostos que compõem esse fator (IPU, IPTU e MELHORIA) são impostos relacionados a capital físico existente nos municípios e essa foi a principal razão para considerar-se esse fator como representativo dessa forma de capital.

Duas variáveis incluídas no segundo componente fazem parte de variáveis representativas de outros estoques de capitais e não do capital físico. A variável TRIBUTO faz parte capital do conjunto de variáveis que representam o estoque de capital financeiro e a variável dummy, do capital natural. A inclusão do total de arrecadação tributária nesse vetor indica que sua correlação é muito maior com esses impostos representativos do capital físico que com qualquer outra fonte de receita do município incluída neste estudo. Quanto à dummy - que indica a existência de belezas naturais e qualidade de água ou do clima - é muito interessante notar que ela compõe um fator com variáveis de capital físico. Dessa composição, conclui-se que capital 
natural e capital físico estariam "caminhando juntos". Além disso, por trás da denominação de estância, um município deve apresentar alguma infra-estrutura e, portanto, também capital físico, necessária para a atividade turística. Por outro lado, a variável dummy representa apenas parcialmente o capital natural. Outras variáveis, bastante representativas desse estoque, formam outros fatores que serão discutidos.

O terceiro componente principal explica 5,9 da variância total e é fortemente correlacionado com variáveis que representam o capital social. As duas maiores cargas que esse fator apresenta são com as organizações políticas (ORGPOLIT) e com as agências de notícias (AGNOTIC). O fato de aparecem juntas e como as duas principais forças desse vetor, faz supor que certo grau de civismo estaria representado nesse fator. Por outro lado, todas as outras variáveis que apresentam altas cargas são variáveis indicadoras da "vida associativa". Essas variáveis são organizações teatro música e outras atividades literárias (ARTE), atividades religiosas (ORGRELIG) e atividades profissionais (ORPROFIS). Outras variáveis relacionadas ao conceito de capital social estão em outro fator. Assim, entende-se seja capital social 1 (associativismo) seja a denominação mais apropriada para o quinto fator.

O quarto fator responde por 4,2 \% da variância total, é formado por variáveis relacionadas à saúde. Isso significa que, assim como o primeiro componente, é um fator que representa o capital humano. As duas maiores cargas desse fator são os números de dentistas (DENTISTA) e médicos (MEDICOS). A carga fatorial da variável número de enfermeiros, embora não tenha atingido o valor de 0,6, é bastante próxima $(0,58792)$ o que reforça ainda mais a constatação de que este fator é, de fato, capital humano (saúde). Lembrando que os fatores são não-correlacionados, é interessante notar que esse aspecto do capital humano, a saúde, tenha formado seu próprio fator. Em outras palavras, pode-se dizer que a separação entre educação e saúde, que juntas fazem parte do estoque de capital humano, é nítida.

Variáveis que representam o capital financeiro estão presentes no quinto e no oitavo fatores. Apenas duas variáveis são responsáveis pelas cargas superiores a 0,6 
existentes no quinto componente principal. Por serem ambas variável de receitas municipais, esse fator recebeu a denominação de capital financeiro 1 (arrecadação). A primeira delas é a variável total da receita arrecadada (TOTALREC) a segunda é a receita municipal de transferências intergovernamentais (INTERGOV). O quinto fator, sozinho é responsável por 3,5\% da variação total dos dados. Com a inclusão do quinto fator, a percentagem total da variância explicada é de 34,4\%. Quanto ao oitavo fator, responsável por 2,5\% da variância, é correlacionado às variáveis operações de crédito (CREDITO) e depósitos totais financeiros (DEPOSITO). Por razões óbvias, esse fator foi denominado capital financeiro 2. Ressalta-se que esses dois fatores juntos respondem por $6 \%$ da variância o que supera, ligeiramente, a explicação da variância dada pelo fator físico.

As variáveis que compõem o sexto fator são claramente variáveis de capital social e explicam 2,8 \% da variância. As três variáveis que apresentaram as maiores cargas são variáveis relacionadas à criminalidade: crimes contra o patrimônio (CRIMEPAT), inquéritos (INQUERIT) e ocorrências policiais (CONCORRENC). Como as correlações entre o fator e as variáveis são positivas, entende-se que o fator cresce com a criminalidade. Como se trata de relacionar tais variáveis a um estoque de capital, considerou-se mais apropriado dizer que o fator cresce com a desconfiança e componente principal foi denominado capital social 2 (desconfiança).

O preço da terra (TERRA) foi a única variável que apresentou carga superior a 0,6 na formação do sétimo fator. Respondendo apenas por 2,6 \% da variância total. Lembrando que a variável utilizada para preço da terra foi a média no EDR, é razoável supor que a percentagem da variância total dos dados, explicada pelo fator terra, poderia ser maior. A falta dos dados de preços por município impede que se investigue essa possibilidade. Como outra variável de capital natural originou o nono fator, o sétimo recebeu a denominação de capital natural 1 (terra).

A variável percentagem de estabelecimentos que realizam a conservação do solo (CONSERVA) é a única variável com a qual o nono fator está correlacionado. A 
responsabilidade desse fator quanto à variância total é de $2,2 \%$. Por estar negativamente relacionado com a variável, o fator cresce à medida em que se eleva a percentagem de estabelecimentos que não fazem a conservação do solo. Espera-se que esses estabelecimentos apresentem uma maior degradação do solo, pois são normalmente necessárias práticas conservacionistas no Estado de São Paulo. A partir disso, entende-se que esse fator representa certo grau de degradação do solo e atribuiu-se a ele a denominação de capital natural (“depreciação”).

A análise apresentada até aqui ainda não permite explicar porque os municípios paulistas são diferentes quanto aos níveis de desenvolvimento, mas esclarecem em quê são diferentes quanto aos estoques de capitais. Os municípios são diferentes principalmente quanto ao estoque de capital humano. É através da redução da percentagem da população com escolaridade inferior a oito anos que a variabilidade seria mais sensivelmente reduzida. Essa constatação é possível graças à composição que os componentes principais apresentaram, nas quais praticamente não houve mistura entre os diferentes estoques de capitais. A única exceção, quanto a esse aspecto, encontra-se no vetor de capital físico. O Quadro 8 sintetiza os resultados obtidos. Depois do capital humano, o estoque de capital social apresentou a maior explicação da variabilidade. Nesses aspectos, os estoques de capitais financeiro e físico são responsáveis por valores bastante próximos. O capital físico, tão enfatizado nos projetos de desenvolvimento, ficou em penúltimo lugar na explicação da variância total dos dados conforme observa-se no Quadro 8. A menor explicação da diversidade existente entre os municípios foi dada pelo capital natural.

\begin{tabular}{|l|c|c|}
\hline \multicolumn{1}{|c|}{ Estoque de Capital } & Fatores Correspondentes & $\begin{array}{c}\text { \% da Variância Total } \\
\text { Explicada }\end{array}$ \\
\hline Capital Humano & Fatores $1^{\circ}$ e $4^{\circ}$ & 19,5 \\
\hline Capital Social & Fatores $3^{\circ}$ e $6^{\circ}$ & 8,3 \\
\hline Capital Financeiro & Fatores $5^{\circ}$ e $8^{\circ}$ & 6,0 \\
\hline Capital Físico & Fator $2^{\circ}$ & 5,9 \\
\hline Capital Natural & Fatores $7^{\circ}$ e $9^{\circ}$ & 4,8 \\
\hline
\end{tabular}

Quadro 8 - Relação entre os fatores obtidos e os estoques de capitais. 


\subsection{Resultados da análise de regressão}

Após sintetizarem, nos fatores identificados na análise de componentes principais, as variáveis de estoques de capitais que mais explicam a grande variabilidade existente nos municípios paulistas, procurou-se estimar a importância desses fatores no desenvolvimento. Foram feitas algumas regressões lineares múltiplas, das quais três serão analisadas neste capítulo. As duas primeiras regressões a serem apresentadas têm, como variáveis dependentes, variáveis de crescimento econômico (número de empregados per capita e número de estabelecimentos de intermediação financeira per capita). Na terceira regressão, o Índice de Desenvolvimento Humano (IDH) é variável explicada. Em todas as regressões, as variáveis dependentes estavam em função de dez variáveis independentes (os noves primeiros componentes principais encontrados e uma variável dummy para municípios lindeiros).

Utilizou-se o método stepwise para o ajuste das regressões. Nesse método, as variáveis entram e saem da equação em seqüência e de acordo com critérios preestabelecidos. O critério de entrada de novas variáveis foi, nesse caso, o valor 0,05 como limite máximo de significância dos valores obtidos no teste $t$ de Student.

Os resultados obtidos na regressão da variável número de empregados per capita em 1996 encontram-se nas Tabelas 1 e 2. Das dez variáveis independentes, seis entraram na equação obtida. Quanto à variável dummy, o fato de não ter sido incluída na solução, significa que os municípios lindeiros não apresentam diferenças, em relação aos outros, quanto aos fatores explicativos do emprego per capita. Esses fatores são, em ordem decrescente de seus respectivos coeficientes: o sétimo, o segundo, o primeiro, o quarto, o quinto e o oitavo componentes principais identificados na análise já discutida. 
Tabela 1. Coeficientes da regressão linear múltipla - variável dependente: número de empregados por habitantes, em 1996.

\begin{tabular}{|c|c|c|c|}
\hline Variável & $\begin{array}{l}\text { Coeficiente de } \\
\text { Regressão }\end{array}$ & Beta & Teste $\mathrm{t}$ \\
\hline Constante & 14,251192 & & $\begin{array}{c}35,296 \\
(0,0000)^{1}\end{array}$ \\
\hline $\begin{array}{l}7 \text { Fator } \\
\text { (capital natural1) }\end{array}$ & 3,165807 & 0,289331 & $\begin{array}{c}7,834 \\
(0000)\end{array}$ \\
\hline $\begin{array}{l}2^{\circ} \text { Fator } \\
\text { (capital físico) }\end{array}$ & 1,659977 & 0,151709 & $\begin{array}{c}4,108 \\
(0,0000)\end{array}$ \\
\hline $\begin{array}{l}1 \text { Fator } \\
\text { (capital humano 1) }\end{array}$ & 1,382500 & 0,126350 & $\begin{array}{c}3,421 \\
(0,0007)\end{array}$ \\
\hline $\begin{array}{l}4^{\circ} \text { Fator } \\
\text { (capital humano } 2 \text { ) }\end{array}$ & 1,345854 & 0,123001 & $\begin{array}{c}3,331 \\
(0,0009)\end{array}$ \\
\hline $\begin{array}{l}5^{\circ} \text { Fator } \\
\text { (capital financeiro } 1)\end{array}$ & 1,161176 & 0,106123 & $\begin{array}{c}2,874 \\
(0,0042)\end{array}$ \\
\hline $\begin{array}{l}8^{\circ} \text { Fator } \\
\text { (capital financeiro) }\end{array}$ & 0,981927 & 0,089741 & $\begin{array}{c}2,430 \\
(0,0154)\end{array}$ \\
\hline
\end{tabular}

${ }^{1}$ nível de significância do teste $t$.

Os sinais de todos os fatores que entraram na equação foram positivos, correspondendo ao que se esperava. Além disso, todos foram significativos, conforme mostram os resultados dos valores do teste $t$, na Tabela 1 . O sétimo fator (capital natural 1) tem o maior coeficiente da regressão. Desse resultado, interpreta-se que terras melhores são mais intensivamente utilizadas e geram mais emprego. Pode-se supor que esses empregos não sejam apenas na agricultura, mas, também, que haja um efeito multiplicador. Esse efeito ampliaria o número de empregos, em municípios cujas terras sejam mais caras, e, por essa razão supostamente melhores. Esse resultado está perfeitamente coerente com a relação entre qualidade da terra e intensificação do uso da mão-de-obra. A segunda maior resposta no número de empregados per capita é dada pelo capital humano, o qual possui seus dois coeficientes na equação ( $1^{\circ}$ e $4^{\circ}$ fatores $) . O$ capital financeiro $\left(5^{\circ}\right.$ e $8^{\circ}$ fatores) também supera o capital físico e o capital social foi excluído da equação ajustada. 
Tabela 2. Coeficientes da regressão linear múltipla e teste $\mathrm{F}$ - variável dependente: estabelecimentos de intermediação financeira existentes em 1996.

\begin{tabular}{lc}
\hline Coeficientes/ Teste & Valor \\
\hline $\mathrm{R}$ Múltiplo & 0,39640 \\
$\mathrm{R}^{2}$ & 0,15714 \\
$\mathrm{R}^{2}$ Ajustado & 0,14895 \\
Erro padrão & 10,09408 \\
Teste F & 19,20251 \\
Nível de significância de F & 0,0000 \\
\hline
\end{tabular}

O coeficiente de determinação ajustado $\left(R^{2}\right)$ indica a percentagem da variação no número de empregados per capita que é explicada pelos fatores presentes na regressão. A Tabela 2 traz esse coeficiente. Apesar de apresentar um valor baixo de $\mathrm{R}^{2}$ ajustado $(0,14895)$, o valor do $\mathrm{F}$, apresentado na mesma tabela, foi muito significativo.

A interpretação dos resultados da segunda regressão a ser apresentada não é tão imediata quanto a daqueles obtidos na primeira. A Tabela 3 traz esses resultados. Os coeficientes com sinais positivos - exceto o $6^{\circ}$ fator - correspondem ao que se esperava. Esses coeficientes indicam que o crescimento do número de estabelecimentos de intermediação financeira per capita aumenta à medida em que crescem os fatores financeiro 1 (arrecadação), humano 2 (saúde) e social 1 (associativimo). A interpretação do sinal do coeficiente do $6^{\circ}$ fator exige que se tenha em mente que a regressão linear não diz respeito à causalidade. $O$ sinal dessa variável apenas evidencia que há relação entre o crescimento do aumento da criminalidade (variável que originou o $6^{\circ}$ fator) e o número de estabelecimentos de intermediação financeira. Parece coerente que crimes contra o patrimônio ocorram mais onde existam mais agências bancárias e, desse modo, o sinal positivo faz sentido.

Para se entenderem os sinais negativos dos coeficientes da Tabela 3, é necessária alguma reflexão. Facilita o entendimento notar que o $8^{\circ}$ fator não entrou na equação. Isso significa que as variáveis operações crédito e depósitos totais financeiros não são importantes para explicar o número de estabelecimentos de intermediação 
financeiros per capita. Outro ponto importante a ser lembrado é que são muitos os pequenos municípios na amostra. A existência de pelo menos uma agência de caixa econômica nesses municípios, gera uma elevada relação estabelecimentos / habitante. É esse o caso de 10,5\% da amostra, ou seja, de 66 municípios. Apenas 1 desses 66 municípios apresentou população acima de dez mil habitantes e todos tinham uma agência da Caixa Econômica. O grande número de municípios com poucos habitantes, ajuda ainda a entender a importância da arrecadação municipal nessa regressão. De fato, o fator financeiro 1 (arrecadação) faz parte da equação obtida conforme já mencionado e que apresenta o maior coeficiente Beta estimado.

Com relação ao sinal do 9o. fator (capital natural 2), a interpretação do sinal do coeficiente também não é óbvia. Sabe-se que, a redução na depreciação do solo que, em geral, é melhor conservado nas regiões do estado nas quais é mais fértil - eleva a produtividade desse recurso natural. Com o aumento da produção agrícola, somado a efeitos desse aumento sobre outros setores da economia, é provável o surgimento de mais estabelecimentos de intermediação financeira. Desse modo, o sinal do $9^{\circ}$ fator precisa, de fato, ser negativo. Por outro lado, sabe-se que regiões com maior disponibilidade de estoques de capital natural e/ ou de humano tendem a apresentar agências bancárias maiores e mais informatizadas. Com isso, o número de estabelecimentos per capita se reduz. Entende-se que essa seja a explicação para os coeficientes negativos do $7^{\circ}$ e do $1^{\circ}$ fatores, conforme verifica-se na Tabela 3. 
Tabela 3. Coeficientes da regressão linear múltipla - variável dependente: estabelecimentos de intermediação financeira per capita, existentes em 1996.

\begin{tabular}{|c|c|c|c|}
\hline Variável & $\begin{array}{l}\text { Coeficiente de } \\
\text { Regressão }\end{array}$ & Beta & Teste $\mathrm{t}$ \\
\hline Constante & 0,223765 & & $\begin{array}{c}45,235 \\
(0,0000)\end{array}$ \\
\hline $\begin{array}{l}5^{\circ} \text { Fator } \\
\text { (capital financeiro 1) }\end{array}$ & 0,039979 & 0,272478 & $\begin{array}{c}8,075 \\
(0,0000)\end{array}$ \\
\hline $\begin{array}{l}4^{\circ} \text { Fator } \\
\text { (capital humano 2) }\end{array}$ & 0,039607 & 0,269942 & $\begin{array}{c}8,000 \\
(0,0000)\end{array}$ \\
\hline $\begin{array}{l}9^{\circ} \text { Fator } \\
\text { (capital natural 2) }\end{array}$ & $-0,027927$ & $-0,190336$ & $\begin{array}{c}-5,641 \\
(0,0000)\end{array}$ \\
\hline $\begin{array}{l}3^{\circ} \text { Fator } \\
\text { (capital social 1) }\end{array}$ & 0,027331 & 0,186275 & $\begin{array}{c}5,521 \\
(0,0000)\end{array}$ \\
\hline $\begin{array}{l}7^{\circ} \text { Fator } \\
\text { (capital natural 1) }\end{array}$ & $-0,027035$ & $-0,184258$ & $\begin{array}{c}-5,461 \\
(0,0000)\end{array}$ \\
\hline $\begin{array}{l}1^{\circ} \text { Fator } \\
\text { (capital humano } 1 \text { ) }\end{array}$ & $-0,026688$ & $-0,181893$ & $\begin{array}{c}-5,391 \\
(0,0000)\end{array}$ \\
\hline $\begin{array}{l}6^{\circ} \text { Fator } \\
\text { (capital social 2) }\end{array}$ & 0,016384 & 0,111667 & $\begin{array}{c}3,309 \\
(0,0010)\end{array}$ \\
\hline
\end{tabular}

O resultado para o coeficiente de determinação ajustado $\left(R^{2}\right)$ e o valor do $F$ obtidos estão na Tabela 4. A percentagem da que variação no número de estabelecimentos de intermediação financeira, explicada pelos fatores presentes na regressão foi de $28,958 \%$ conforme o $\mathrm{R}^{2}$ ajustado. $\mathrm{O}$ valor do $\mathrm{F}$, também nessa regressão muito foi significativo

Tabela 4. Coeficientes da regressão linear múltipla e teste F - variável dependente: estabelecimentos de intermediação financeira existentes em 1996.

\begin{tabular}{ll}
\hline Coeficientes/ Teste & Valor \\
\hline $\mathrm{R}$ Múltiplo & 0,54548 \\
$\mathrm{R}^{2}$ & 0,29754 \\
$\mathrm{R}^{2}$ Ajustado & 0,28958 \\
Erro padrão & 0,12367 \\
Teste F & 37,33538 \\
Nível de significância de $\mathrm{F}$ & 0,0000 \\
\hline
\end{tabular}


A terceira regressão ajustada apresentou resultados muito compatíveis com a teoria de desenvolvimento discutida no presente estudo. Maiores níveis desenvolvimento são esperados com maiores disponibilidades dos estoques de capitais. Isso implica em sinal positivo para todos os coeficientes que entraram na equação e negativo para a depreciação do capital natural (fator 9). Além disso, sabe-se que a importância do capital físico é maior nos estágios iniciais do desenvolvimento. Evidentemente, isso está longe da realidade da economia paulista, mesmos nas regiões nas quais é menos dinâmica. Faz sentido, portanto. que esse estoque tenha sido o único a não participar da equação ajustada, cujos resultados verifica-se na Tabela 5. Nota-se, ainda na mesma Tabela, que os coeficientes foram todos significativos, conforme o teste $t$.

Tabela 5. Coeficientes da regressão linear múltipla - variável dependente: IDH de 1996.

\begin{tabular}{lccc}
\hline \multicolumn{1}{c}{ Variável } & $\begin{array}{c}\text { Coeficiente de } \\
\text { Regressão }\end{array}$ & Beta & Teste t \\
\hline Constante & 0,775025 & & 436,836 \\
& 0,034635 & 0,474305 & $(0,0000)$ \\
Fator 1 & & 19,506 \\
(capital humano 1) & $-0,030518$ & $-0,417933$ & $(0,0000)$ \\
Fator 9 & & $-17,188$ \\
(capital natural 2) & 0,25759 & 0,352753 & $(0,0000)$ \\
Fator 4 & 0,20429 & 0,279762 & 14,507 \\
(capital humano 2) & & & $(0,0000)$ \\
Fator 7 & & 11,505 \\
(capital natural 1) & 0,011243 & 0,153964 & $(0,0000)$ \\
Fator 8 & & 6,332 \\
(capital financeiro 2) & 0,006755 & 0,092507 & $(0,0000)$ \\
Fator 3 & & & 3,804 \\
(capital social 1) & & & $(0,0002)$ \\
\hline
\end{tabular}

O coeficiente de determinação ajustado $\left(R^{2}\right)$, foi de $63,47 \%$ e o valor do $F$ obtido foi altamente significativo e encontram-se na Tabela 6. A limitação dessa regressão reside no fato de a variável dependente ser um índice formado por variáveis de estoque de capitais (variáveis educação, longevidade e renda) 
Tabela 6. Coeficientes da regressão linear múltipla e teste F - variável dependente: IDH.

\begin{tabular}{ll}
\hline Coeficientes/ Teste & Valor \\
\hline $\mathrm{R}$ Múltiplo & 0,79662 \\
$\mathrm{R}^{2}$ & 0,63460 \\
$\mathrm{R}^{2}$ Ajustado & 0,63105 \\
Erro padrão & 0,4435 \\
Teste F & 178,88055 \\
Nível de significância de F & 0,0000 \\
\hline
\end{tabular}

É importante observar que em nenhuma das três regressões lineares múltiplas apresentadas neste capítulo, a variável dummy lindeiros foi incluída na solução. Assim, os resultados indicam que não há diferença entre os municípios do estado de São Paulo lindeiro e os outros do estado, quanto a importância dos estoques de capitais, na explicação das variáveis dependentes. 


\section{CONCLUSÕES}

Algumas das conclusões que este estudo possibilita dizem respeito não apenas ao Vale do Tietê-Paraná, mas a todo o Estado de São Paulo. São conclusões tiradas a partir da análise na qual se procurou atingir o terceiro objetivo deste estudo. Esse objetivo foi verificar possíveis diferenças, entre os fatores determinantes do desenvolvimento, existentes entre os municípios paulistas lindeiros aos rios Tietê-Paraná e os outros municípios do estado. A análise empírica realizada permite dizer que as causas que melhor explicam o menor desenvolvimento dos municípios lindeiros não podem ser consideradas particularidades desses municípios. Além disso, os municípios lindeiros também não estão usufruindo de possíveis vantagens de serem lindeiros.

Específicas quanto aos municípios do Vale do Tietê-Paraná, são as conclusões sobre as alternativas propostas para esses municípios, que constam nos projetos e planos analisados. Esses são altamente inconsistentes, conforme se detectou através do Método da Estrutura Lógica. Chama a atenção, por exemplo, o fato de as alternativas propostas para o desenvolvimento da região serem fortemente vinculadas à hidrovia Tietê-Paraná e terem fortes pressupostos relacionados ao seu sucesso. A grande maioria desses pressupostos, entretanto não estão explicitados nos planos e projetos. Acrescenta-se a essa constatação, a falta de propostas para o desenvolvimento, que estejam em conformidade coma teoria do desenvolvimento. Os projetos enfatizaram investimentos em capital físico e desconsideram as outras formas de capital e suas relações com o desenvolvimento. 
Com relação aos cinco estoques de capitais, conclui-se que os municípios do Estado de São Paulo são diferentes principalmente quanto à disponibilidade do estoque de capital humano. A base dessa conclusão são os resultados da análise das variáveis representativas do estoque de capital pelo método dos componentes principais. Esse método forneceu os fatores que explicam a variância das variáveis originais. O fator composto por variáveis de educação foi o primeiro componente principal identificado e o fator formado por variáveis relacionadas à saúde foi o quarto componente. Juntos, explicaram 19,6\% da variância total dos dados da amostra composta por 625 municípios paulistas.

O segundo estoque de capital a explicar a maior porcentagem da variância total dos dados é o capital social. Explicou 8,3\% e foi formado por dois componentes: o associativismo (com certo "grau de civismo" incluído nesse fator) e a confiança. Os estoques de capitais financeiro e físico foram responsáveis por valores bastante próximos. O primeiro explicou $6 \%$ da variabilidade e o segundo 5,9\% . O capital físico, tão enfatizado nos projetos de desenvolvimento, ficou em penúltimo lugar na explicação da variância total dos dados. A menor explicação da diversidade existente entre os municípios foi dada pelo capital natural. Mesmo assim, a importância desse estoque de capital para o crescimento econômico está longe de ser insignificante.

O capital natural explicou pouco da variância total dos dados mas mantêm-se importante para explicar o crescimento. O preço da terra foi o fator com maior coeficiente na equação de regressão que explica o emprego per capita. Essa variável foi explicada também, pelo capital humano, financeiro e físico. Tanto o capital humano quanto o financeiro entraram na solução com seus dois respectivos fatores identificados na análise de componentes principais. Mais precisamente, a educação e a saúde apresentaram o terceiro e o quarto maiores coeficientes da equação, o total da receita arrecadada pelo município foi o quinto maior coeficiente encontrado e, em último lugar, o fator composto pelas operações de crédito e depósitos totais financeiros. O capital físico apresentou o segundo maior coeficiente encontrado análise e o capital social não fez parte da solução encontrada. 
Os fatores que melhor explicam a variável estabelecimentos de intermediação financeira, não são os mesmos que explicam o número de empregos. O capital social, que sequer entrou na explicação do emprego, teve seu papel detectado na explicação da variável número de estabelecimentos de intermediação financeira. Por outro lado, o capital físico não fez parte da solução dessa variável dependente. Operações de crédito e depósitos não explicam o número de estabelecimentos per capita, mas sim outro componente do capital físico, o total de receita arrecadada pelo município. Na realidade, esse último apresentou o maior coeficiente na regressão.

A disponibilidade de estoques de capital humano e capital natural não apresentam um resultado muito óbvio, quanto à importância na explicação do número de estabelecimentos de intermediação financeira per capita. Os resultados indicaram respostas negativas para os estoques de capitais humano e natural. Uma provável explicação para essa aparente contradição entre os resultados obtidos e a teoria pode ser formulada a partir de informações adicionais. Sabe-se que existência de um município não requer uma agência bancária, mas é quase impossível manter a autonomia necessária sem pelo menos uma agência local. Em geral, esse papel é desempenhado por Caixas Econômicas. Como é elevado o número de pequenos municípios nesse estágio de desenvolvimento econômico, o reflexo da alta relação estabelecimentos/habitantes influiu nos resultados. Nessa linha de raciocínio, é também mais fácil entender a importância da arrecadação municipal na variação do número de estabelecimentos em detrimento do crédito e dos depósitos totais. Ocorre que, nos municípios pequenos, grande parte dos salários - quase sempre pagos na única agência bancária local provém da prefeitura municipal. Considerando que essa situação ocorra principalmente em regiões de solos mais pobres, nas quais a escolaridade da população é menor que a média do estado, os sinais negativos dos coeficientes encontrados na regressão fazem sentido. Além disso, nas regiões mais ricas do estado, as agências bancárias são maiores, informatizadas e atendem maior número de pessoas. O porte das agências bancárias, se considerado, pode elucidar o papel dos estoques natural e humano na explicação do número de estabelecimentos de intermediação financeira per capita. 
As principais conclusões a que se chegaram neste estudo relacionam-se a uma conclusão mais ampla relativa à falta de propostas, para o Vale do Tietê-Paraná, que estejam em conformidade com a teoria do desenvolvimento. Os resultados da análise empírica indicam que não há diferença entre os municípios paulistas lindeiros ao TietêParaná e os outros municípios do estado de São Paulo, quanto ao papel dos cinco estoques de capital na explicação do desenvolvimento. Evidentemente, esse estudo tem a limitação de se basear apenas em informações de um dado "instante", sem que efeitos ao longo do tempo tenham sido captados. 
ANEXO: Área do Projeto Calha e suas sub-regiões 


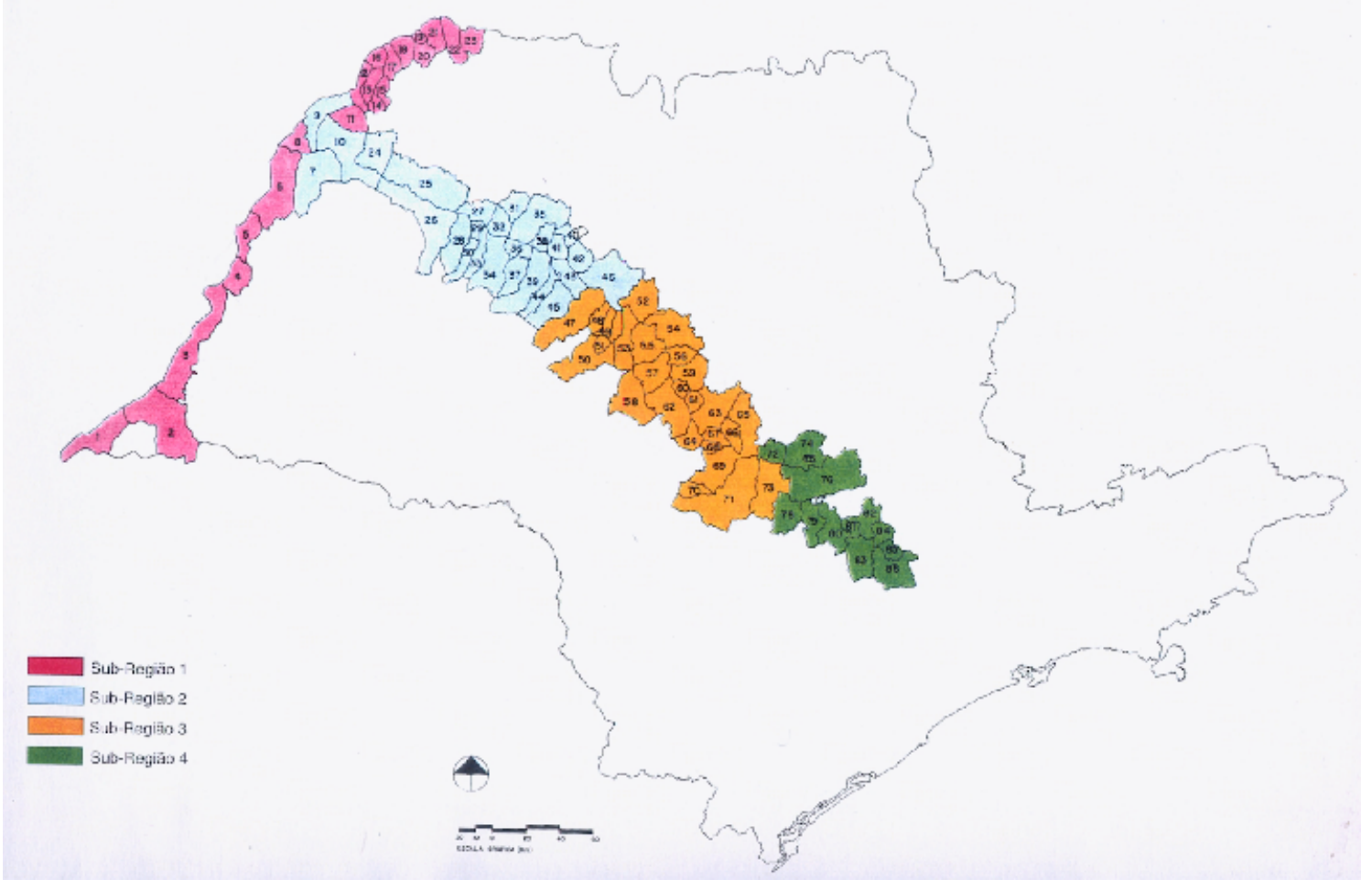

Mapa 1 - Área do Projeto Calha e suas sub-regiões. 


\section{REFERÊNCIAS BIBLIOGRÁFICAS}

\section{AGÊNCIA DE DESENVOLVIMENTO TIETÊ-PARANÁ. Tietê-Paraná Master}

Plan: infra-estrutura, mercado \& negócios. São Paulo: ADTP, 1996. 303p.

ALMEIDA, T.L. Análise fatorial.hinttp://lula.dmat.furg.br/ taba/posanafat.htm (12 out. 2001)

ALVES, A.F. Análise de qualidade de vida e grupos sociais organizados em Vera Cruz, Estado de São Paulo. Piracicaba, 1996. 152p. Dissertação (Mestrado) - Escola Superior de Agricultura "Luiz de Queiroz", Universidade de São Paulo.

ANDRADE, T.A.; LODDER, C.A. Cidades médias no Brasil. Rio de Janeiro: IPEA/ INPES, 1980. (Relatórios de Pesquisa, 43)

BANCO MUNDIAL. Relatório sobre o desenvolvimento mundial - 1991: o desafio do desenvolvimento. Rio de Janeiro: FGV, 1991. 313p.

BARROS, R.; FOGEL, M.; MENDONÇA, R. Perspectivas para o mercado de trabalho brasileiro ao longo da próxima década. Estudos Econômicos, v.27, n.especial, p.736, 1997.

BOISIER, S. Em busca do esquivo desenvolvimento regional: entre a caixa-preta e o projeto político. Planejamento e Políticas Públicas, n.13, p.111-145, jun. 1996.

BOISIER, S. Política econômica, organização social e desenvolvimento regional. In: HADDAD, P.R. Economia regional: teoria e métodos de análise. Fortaleza: Banco do Nordeste do Brasil, 1989. cap.11, p.589-687. 
BRASIL. Departamento Nacional de Produção Mineral. Anuário Mineral Brasileiro 1997. http//www.dnpm.gov.br/97616.doc (08 fev. 2002)

BRASIL. Ministério do Trabalho e do Emprego. Secretaria de Políticas de Emprego e Salário. RAIS - Relação Anual de Informações Sociais - 1996 (compact disc). Brasília: MTE, 1997.

BRASIL. Ministério do Trabalho e do Emprego. Secretaria de Políticas de Emprego e Salário. RAIS - Relação Anual de Informações Sociais. 'htttp://wwww.mte.gov.b̄! (08 jan. 2002)

CANO, W. Perspectivas para a questão regional. Ensaios FEE, v.15, n.2, p.312-20, 1994.

CARTA do IBRE. Conjuntura Econômica, v.43, n.12, p.9, dez. 1989.

COLEMAN, J.S. Foundations of social theory. Cambridge: The Belknap Press of Harvard University Press, 1990. cap.12, p.300-321: Social capital.

COMPANHIA ENERGÉTICA DE SÃO PAULO. Município de Rosana: macroplano turístico e industrial. São Paulo: CESP, 1993. 29p. (Série Pesquisa e Desenvolvimento, 90)

COMPANHIA ENERGÉTICA DE SÃO PAULO. Plano de fomento turístico: Rubinéia, Santa Fé do Sul e Três Fronteiras. São Paulo: CESP, 1995a. 88p. (Série Pesquisa e Desenvolvimento, 134)

COMPANHIA ENERGÉTICA DE SÃO PAULO. Estância Turística de Ibitinga: macroplano de desenvolvimento turístico de Ibitinga. São Paulo: CESP, 1995b. 42p. (Série Pesquisa e Desenvolvimento, 106)

COMPANHIA ENERGÉTICA DE SÃO PAULO. Hidrovia Tietê-Paraná: plano de fomento. São Paulo: CESP, 1996. 47p. (Série Pesquisa e Desenvolvimento, 133) 
COMPANHIA ENERGÉTICA DE SÃO PAULO. Hidrovia Tietê-Paraná. Hidrovia do Mercosul: um rio de negócios. São Paulo: CESP, 1997a. 25p. (Série Divulgação de Informação, 206)

COMPANHIA ENERGÉTICA DE SÃO PAULO. Plano de desenvolvimento e integração hidroviário de Penápolis. São Paulo: CESP, 1997b. 22p. (Série Pesquisa e Desenvolvimento, 142)

COMPANHIA ENERGÉTICA DE SÃO PAULO. Plano de fomento turístico: Buritama, Lourdes, Turiuba e Zacarias. São Paulo: CESP, 1998. 46p. (Série Pesquisa e Desenvolvimento, 144)

CONSÓRCIO INTERMUNICIPAL TIETÊ-PARANÁ. Tietê-Paraná: Projeto Calha caracterização da área do projeto. São Paulo: CTIP, 1994. 67p.

DIAS, C.T. dos S.; LIMA, C.G.; NOGUEIRA, M.C.S. Estatística multivariada através do SAS para Windows. Piracicaba: ESALQ/USP, 1996. 111p.

DONADELli, A.; COELHO, P.J.; NEGRI NETO, A.; SANTOS, Z.A.P. de; CAMARGO FILHO, W.P. de; CAMARGO, L.B. Atividade agropecuária no Estado de São Paulo: distribuição e valor da produção por Escritório de Desenvolvimento Rural, 1995/96 e 1996/97. Informações Econômicas, v.27, n.12, p.21-31, dez. 1997.

ECKELUND JUNIOR, R.B.; HEBERT, R.F. A history of economic theory and methoded international student. Tokyo: McGraw-Hill Kogakusha Ltda, 1975. p.207-245: Cournot and Dupuit: the origins of formal microanalysis.

FARRENBERG, M.L.A. A hidrovia Tietê-Paraná e a dinâmica dos municípios: um estudo de caso. São Paulo, 1998. 111p. Dissertação (Mestrado) - Faculdade de Arquitetura e Urbanismo, Universidade de São Paulo. 
FERREIRA, C.M. de C. Espaço, regiões e economia regional: In: HADDAD, P.R. Economia regional: teoria e métodos de análise. Fortaleza: Banco do Nordeste do Brasil, 1989a. cap.1, p.45-65.

FERREIRA, C.M. de C. As teorias da localização e a organização espacial da economia. In: HADDAD, P.R. Economia regional: teoria e métodos de análise. Fortaleza: Banco do Nordeste do Brasil, 1989b. cap.2, p.67-206.

FERREIRA, C.M. de C. Métodos de regionalização. In: HADDAD, P.R. Economia regional: teoria e métodos de análise. Fortaleza: Banco do Nordeste do Brasil, 1989c. cap.10, p.509-588.

FRY, M.J. Money, interest, and banking in economic development. 2ed. Baltimore: The Johns Hopkins Press, 1995. 568 p.

FUNDAÇÃO SISTEMA ESTADUAL DE ANÁLISE DE DADOS. Anuário estatístico do Estado de São Paulo. São Paulo: SEADE, 1994. 965p.

FUNDAÇÃO SISTEMA ESTADUAL DE ANÁLISE DE DADOS. Informações dos municípios paulistas. http://www.seade.gov.br (01 jun. 2002a)

FUNDAÇÃO SISTEMA ESTADUAL DE ANÁLISE DE DADOS. Coletânea de Tabelas. hittp:///www.seade.gov.bili (01 jun. 2002b)

HADDAD, P.R. Economia regional: teoria e métodos de análise. Fortaleza: Banco do Nordeste do Brasil, 1989. Notas do organizador.

HADDAD, P.R.; BONELLI, R. (Coord.). Desenvolvimento humano e condições de vida: indicadores brasileiros. Brasília: PNUD/IPEA/FJP, 1998a. 140p. (Coleção Desenvolvimento Humano - Projeto "Desenvolvimento Humano no Brasil")

HADDAD, P.R.; BONELLI, R. (Coord.). Atlas do desenvolvimento humano no Brasil (compact disc). Brasília: PNUD/IPEA/FJP, 1998b. 
HESPANHOL, A.N. Dinâmica agroindustrial, intervenção estatal e a questão do desenvolvimento da região de Andradina - SP. Rio Claro, 1996. 273p. Tese (Doutorado) - Instituto de Geociências e Ciências Exatas, Universidade Estadual Paulista "Julio de Mesquita Filho".

HIRIART, M.M.M.; SILVA, P.F. da; RUIVO, J.C.A.A; BELATO, J.; SILVA, C.G. da. Associações de produtores rurais do Estado de São Paulo: informações básicas. São Paulo: ICA, 1999. 191p. (Série Estudos e Pesquisas, 1/99)

HOFFMANN, R. Componentes principais e análise fatorial. Piracicaba: ESALQ/USP, 1999. 40p. (Série Didática, 90)

INSTITUTO BRASILEIRO DE GEOGRAFIA E ESTATÍSTICA. Censo Agropecuário. http://www.ibge.gov.br (06 jun. 2002)

JACKSON, B. Designing projects and project evaluation using the Logical Framework Approach. Gland: IUCN - The World Conservation Union, 1998. http://Www.iunc.org/themes/eval/english/1fahtm (18 jun. 2001)

KNACK, S.; KEEFER, P. Does social capital have an economic payoff ? A crosscountry investigation. Quarterly Journal of Economics, v.112, n.4, p.1251-1288, Nov. 1997.

LAVINAS L.; MAGINA, M.A. Federalismo e desenvolvimento regional: debates da revisão constitucional. Rio de Janeiro: IPEA, 1995. 30p. (Texto para Discussão, 390)

LUCAS, R.E. On the mechanics of economic development. Journal of Monetary Economics, v.22, n.1, p.3-42, 1988.

MAlhotra, N.K. Pesquisa em marketing. Porto Alegre: Bookman, 2001. cap.19, p.503-534: Análise fatorial. 
MARTIN, N.B. O poder do desenvolvimento rural. Informações Econômicas, v.23, n.12, p.27-35, dez.1993.

MEDRANO, L.I.Z. de. A livre navegação dos rios Paraná e Uruguay: uma análise do comércio entre o império brasileiro e a Argentina (1852-1889). São Paulo, 1989. 403p. Tese (Doutorado) - Instituto de Filosofia e Ciências Humanas, Universidade de São Paulo.

MILL, J.S. Princípios de Economia Política. São Paulo: Nova Cultural, 1996. cap.4, p.109-117: O capital. (Coleção Os Economistas)

MILLER, R.E.; BLAIR, P.D. Input-output analysis: foundations and extensions. Englewood Cliffs: Prentice-Hall, 1985. 464p.

MONBEIG, P. Pioneiros e fazendeiros de São Paulo. São Paulo: Editora Hucitec, 1984. 392p.

MÜLLER, A.C. Hidrelétricas, meio ambiente e desenvolvimento. São Paulo: Makron Books, 1995. 412p.

ORGANIZAÇÃO DAS COOPERATIVAS BRASILEIRAS. Anuário do Cooperativismo Brasileiro - 2000. Brasília: OCB, 2001. 172p.

OHMAE, K. O fim do Estado-nação. Rio de Janeiro: Editora Campus; São Paulo: Publifolha, 1999. 214p.

OLIVEIRA, G. Brasil - FMI: realidades e mitos artigo4.htm (31 mar. 1999)

PEREIRA, G.H. Política industrial, instituições locais e desenvolvimento racional: o caso do Espírito Santo. Campinas, 1996. 254p. Tese (Doutorado) - Instituto de Economia, Universidade Estadual de Campinas. 
PERES, F.C. Capital social: a nova estrela do crescimento econômico. Preços Agrícolas, v.14, n.163, p.6-9, maio 2000.

PERES, F.C.; RASK, N. Interest rates, inflation, and the burden of debt repayment: implications for U.S. agricultural exports to debtor countries. Ohio's Challenge, The magazine of agricultural economics and rural sociology, v.3, n.1, Winter 1990.

PRUGH, T. Natural capital and human economic survival. Solomons: International Society for Ecological Economics, 1995. 198p.

PUTNAM, R.D. Making democracy work: civic traditions in modern Italy. Princeton: Princeton University Press, 1993. 258p.

REYES, M.V. A questão regional na Argentina: origens, revisão crítica do papel do Estado no tratamento do problema e dilemas para o futuro. Campinas, 1996. Dissertação (Mestrado) - Instituto de Economia, Universidade Estadual de Campinas.

RICARDO, D. Princípios de Economia Política e Tributação. São Paulo: Nova Cultural, 1996. cap.2, p.49-62: Sobre a renda da terra. (Coleção Os Economistas)

SACHS, J.D.; LARRAIN, F. Macroeconomia. São Paulo: Makron, 1995. cap.18, p.615-645: Crescimento a longo prazo.

SÃO PAULO (Estado). Secretaria de Esporte e Turismo. Plano de desenvolvimento turístico da Hidrovia Tietê/ParanáSão Paulo: SET/ CESP, 1986. 18p.

SÃO PAULO (Estado). Secretaria de Economia e Planejamento. Desenvolvimento Humano no Estado de São Paulo. São Paulo, 1999. 57p.

SÃO PAUlO (Estado). Assembléia Legislativa de São Paulo. Cadernos do Fórum: São Paulo Século XXI. São Paulo: Imprensa Oficial do Estado de São Paulo, 2000. $4 \mathrm{v}$. 
SCHUH, G.E. The economic organization of world agriculture. /Apresentado em 6 de agosto de 1998 como Seminário do Departamento de Economia, Administração e Sociologia da Escola Superior de Agricultura "Luiz de Queiroz", Universidade de São Paulo, Piracicaba, 1998/

SEN, A. Desenvolvimento como liberdade. São Paulo: Companhia das Letras, 2000. 409 p.

SHAFFER,W.A. Regional impact models. TOC.html (06 jul. 2000)

SHARMA, S. Applied multivariate techniques. New York: John Wiley, 1996. chap.4, p.58-89: Principal components analysis; chap.5, p.90-123: Factor analysis.

SOLOW, R. A contribution to the theory of economic growth. Quarterly Journal of Economics, v.70, p.65-94, 1956.

SOUZA, M.P. Parecer EPIA “Aproveitamento Múltiplo Santa Maria da Serra”. São Carlos: Diretoria do Centro de Recursos Hídricos e Ecologia Aplicada, Departamento de Hidráulica e Saneamento, Escola de Engenharia de São Carlos, Universidade de São Paulo 1999. 6p. (Parecer técnico apresentado ao Conselho Estadual do Meio Ambiente, São Paulo)

STERN, N. Growth theories, old and new, and the role of agriculture in economic development. London: London School of Economics, 1994. (Paper 17/42) 